\title{
LA PRODUCCIÓN LEXICOGRÁFICA CON EL ESPAÑOL Y EL FRANCÉS DURANTE LOS SIGLOS XVI A XIX
}

\author{
Manuel Bruña Cuevas \\ Universidad de Sevilla
}

\section{RESUMEN}

Este estudio analiza la historia de la producción lexicográfica bilingüe $y$ multilingüe que reúne la lengua francesa y la española desde el siglo XVI hasta el XIX: diccionarios, vocabularios alfabéticos, nomenclaturas temáticas, glosarios técnicos...

Palabras clave: lexicografia bilingüe; lexicografia multilingüe; diccionarios francés-español; diccionarios español-francés; nomenclaturas.

\section{ABSTRACT}

This study looks at the history of bilingual and multilingual lexicographical production that brings together French and Spanish from the sixteenth to the nineteenth century: dictionaries, alphabetical or thematic vocabularies, technical glossaries...

Keywords: bilingual lexicography; multilingual lexicography; French-Spanish dictionaries; Spanish-French dictionaries; thematic vocabularies.

En este estudio ${ }^{1}$ vamos a trazar un panorama general del desarrollo y principales características de las obras que, más o menos directamente, ponen en relación el léxico del francés con el del español dentro del marco temporal que va del siglo XVI al XIX, ambos incluidos ${ }^{2}$.

\footnotetext{
${ }^{1}$ Este estudio se inscribe en el proyecto de investigación "Elaboración de un diccionario de la presencia y enseñanza del francés en España, siglos XVI-XX”, financiado por el Ministerio de Ciencia e Innovación (FFI2008-02389/FILO).

${ }^{2}$ Entre los catálogos bibliográficos donde se encuentran recopiladas muchas de las obras que comentaremos, por el momento citaremos tan solo, por abarcar varios siglos, los de Quemada (1968) y Lindemann (1994), centrados en la lexicografía histórica con el francés, y Bajo Pérez (2000), centrada en la del español. Véanse asimismo los de Suárez Gómez (1961: 330-346), desde el siglo XVI a 1850; Fabbri (1979: 131-142), para los siglos XVI a XX San Vicente (1995) para el XVIII, y los tres tomos, uno por siglo (del XVI al XVIII), de la BICRES de Niederehe $(1994,1999,2005)$. Se encontrará un panorama comentado de varios siglos de la lexicografía francoespañola en Niederehe (1987; desde el siglo XVI a 1800), Verdonk (1991) y Carriscondo et alii (2000: 275-284). Sobre el campo lexicográfico conformado por los vocabularios en que el léxico se ordena por afinidad temática, puede verse el trabajo de Ayala Castro (1992), el cual, al versar sobre las nomenclaturas con el español, reserva amplio espacio a las bilingües o multilingües que también contienen el francés, si bien la última de este tipo citada es de 1781. Entre las tesis centradas, totalmente o en gran parte, en la producción lexicográfica española de varios siglos, véanse la de Suárez Gómez (1956), que comprende desde el siglo XVI a 1850, la de Cazorla Vivas (2002a), sobre los siglos XVIII y XIX, y la de Pablo Núñez (2008a), sobre los siglos XVI y XVII, trabajo este último de cuyo interés no dudamos por más que no hayamos podido leerlo al no estar aún publicado. Para otras referencias
} 


\section{SiGLO XVI}

Las lenguas española y francesa aparecen confrontadas por primera vez en $1526^{3}$, concretamente en el Vocabulario de cinco lenguas Latina, Italiana, Francesa, Espagnola \& Alemana, publicado en Venecia por Francesco Garrone. Se trata de la más temprana versión quintilingüe del Introito e porta de Adamo de Rodvila, aparecido primeramente en Venecia, en 1477, en versión bilingüe italiano-alemán, y del que existía desde 1510 una versión cuatrilingüe por adjunción del latín y el francés. Estamos ante una obrilla con listados de vocablos en columnas paralelas, una por cada lengua. Las voces conforman una nomenclatura, es decir, se distribuyen por grupos temáticos, sobre todo en la primera parte; la segunda y última parte de esta cartilla, sin abandonar la distribución temática, responde a veces también a una distribución gramatical (infinitivos, participios, locuciones, preguntas, etc.). Tras la edición de 1526, la obra fue reeditada constantemente hasta 1636 en diversas ciudades, ninguna de ellas española, y fue enriqueciéndose con otros idiomas hasta llegar a su versión octolingüe, siempre con inclusión del francés y el español.

Junto a esta serie políglota se desarrolló otra que partió de presupuestos diferentes. El maestro de lenguas Noël Berlaimont publicó en Amberes hacia $1530^{4}$ unos diálogos y modelos de cartas bilingües flamenco-francés, acompañándolos de un vocabulario, igualmente bilingüe, organizado por orden alfabético a partir de las entradas flamencas. En 1551 aparece en Lovaina la primera versión de la obra con el español: es el Vocabulario de quatro lenguas, Tudesco, Frances, Latino, y Español, impreso por Bartolomé Gravio. Enriquecido posteriormente con nuevos materiales didácticos, conocerá numerosas reediciones a lo largo de los siglos XVI y XVII, en versiones que van hasta las ocho lenguas. En ellas es constante la presencia del francés y habitual la del español, si bien para los nativos de estas lenguas no debió ser siempre fácil la consulta del léxico debido a que la distribución de las palabras seguía a menudo el primitivo orden alfabético de las entradas flamencas, inclusive en aquellas ediciones en que este idioma ni siquiera figuraba en el conjunto políglota. Por ello, cualquiera que pudiera ser la utilidad de esta obra en lo que atañe al aprendizaje de otros aspectos de la lengua, en lo que toca a los listados de vocabulario nos parece menos provechosa que la otra serie que existió paralelamente y a la que ya nos hemos referido, es decir, la serie derivada del Introito e porta de Adamo de Rodvila ${ }^{5}$.

sobre catálogos bibliográficos que atañen al tema de este estudio, así como sobre otros recorridos comentados de la historia lexicográfica francoespañola, pueden consultarse los trabajos que hemos dedicado especialmente a consignar tales datos (Bruña Cuevas 2003, 2008a). Para un panorama de la metalexicografía del español, remitimos a Ahumada $(2006,2009)$

${ }^{3}$ Nos referimos a que aparecen confrontadas por vez primera en vocabularios de interés lexicográfico. No tienen ese carácter lexicográfico, pese a su título (Vocabulario para aprender franches, espannol y flaminco) las obras trilingües francés-español-flamenco publicadas en Amberes por Vorsterman en 1520 y 1530.

${ }^{4}$ La primera versión de esta obra que nos ha llegado corresponde, no obstante, a la edición de 1536.

${ }^{5}$ Sobre los vocabularios políglotas temáticos o alfabéticos del XVI, véanse Bourland (1933), Verdeyen (19251935), Gallina (1959), Rossebastiano Bart (1984), Alvar Ezquerra (1991), Colombo Timelli (1992, 1993), Nieto Jiménez (2000a, 2000b), Acero Durántez (2003, 2008), García Aranda (2003), Martínez Egido (2006), Redondo Rodríguez (2006a), Corvo Sánchez (2007a). 
Tanto la presentación de listados políglotas de léxico por orden alfabético como su presentación por apartados temáticos conocieron un desarrollo mayor en el siglo XVI que el que acabamos de señalar. En ordenación alfabética destacó el Dictionarium de Ambrosio Calepino, que, publicado por primera vez en 1502, en Reggio Emilia, como un diccionario latino con algunas equivalencias griegas, las incorporó progresivamente en otras lenguas, entre ellas el español y el francés, hasta llegar a once idiomas antes de finalizar el siglo XVI. Aunque el español ya se incorpora en 1559 a una edición cuatrilingüe de Lyon (latíngriego-italiano-español), habrá que esperar a la también edición lionesa de 1565 (latíngriego-italiano-francés-español) para que aparezca por primera vez junto al francés. Ambos idiomas se encontrarán en las numerosísimas ediciones de la obra realizadas desde esa fecha hasta bien avanzado el siglo XVIII, las cuales conservaron siempre su estructura primitiva de entradas y definiciones en latín y equivalentes en lenguas diversas ${ }^{6}$.

En cuanto al ámbito de la presentación del léxico por campos temáticos, destaca primeramente la obra de Hadrianus Junius. Su Nomenclator omnium rerum propria nomina variis linguis explicata indicans (Amberes, 1567) es una extensísima nomenclatura con las entradas en latín y correspondencias en griego, alemán, neerlandés, francés, italiano, español e inglés, si bien pueden faltar los equivalentes en alguna de estas lenguas para ciertas entradas; de hecho, su ausencia es lo más común en el caso del inglés, contrariamente a los equivalentes en alemán y neerlandés, que figuran casi siempre. Esta nomenclatura se granjeó un gran éxito, conociendo muchas reediciones en que podía cambiar el número de lenguas, por lo que no todas reúnen el francés y español. Pese a ello, las reediciones con nuestras dos lenguas se sucederán aún durante los primeros decenios del siglo XVII, conservando siempre, pese a alguna reestructuración más o menos afortunada, su carácter de gran nomenclatura temática ${ }^{7}$. Menor recorrido temporal tuvo, en cambio, la Sylva vocabulorum et phrasium, sive Nomenclator octo linguarum, de Heinrich Decimator, una amplia nomenclatura con las entradas en latín y equivalencias en hebreo, griego, italiano, francés, español, alemán y neerlandés. Deriva de una primera versión de la obra fechada en 1580, bastante diferente, con el léxico dispuesto por orden alfabético y solo trilingüe alemán-griego-latín. Ya con disposición temática, reúne por primera vez el francés y el español en su edición de 1596, base de la última de 1606. Aunque las equivalencias alemanas y francesas suelen aparecer constantemente, las españolas, como ya era el caso en el Nomenclator de Junius, faltan muchas veces ${ }^{8}$.

Los listados léxicos políglotas también se encuentran en obras que no son propiamente de tipo lexicográfico; así, en la Historia animalium (cinco volúmenes, 1551-1587), de Conrad Gesner, cada uno de cuyos libros presenta en preliminares un listado con los

\footnotetext{
${ }^{6}$ Sobre el Calepino véase la Bibliographie de Labarre (1975).

${ }^{7}$ En 1602, por ejemplo, el orden de los bloques temáticos se cambia para disponerlos alfabéticamente según su título. Esta operación, si bien podía facilitar la consulta de la obra en ciertos casos, rompía no obstante la sucesión primitiva de los apartados por afinidad temática de sus contenidos, lo cual pudo ser una razón para que reediciones posteriores, como la de Fráncfort de 1620, se mantuvieran fieles al orden de los bloques establecido por Junius.

${ }^{8}$ Sobre Junius, véanse Martín Gamero (1961: 69-71), Acero Durántez (1992), Breva Claramonte (2003: 86-87). Sobre Decimator, Gallina (1959:189-204), Acero Durántez (1996). Sobre ambos autores, Acero Durántez (1993), García Aranda (2003: 107-109, 112-115).
} 
nombres de los animales de los que se trata en la obra. Son listados en más de diez lenguas antiguas y modernas, europeas o no (latín, hebreo, griego, árabe, turco, italiano, alemán, francés, español, inglés, polaco y otras), y distintamente surtido en número de ítems según el idioma, siendo siempre el primero y mejor representado el latino y hallándose el francés y el español en todos los listados (el primero más copiosamente que este). Debido a que su finalidad no es lexicográfica, estos listados no ofrecen los equivalentes entre las diversas lenguas en columnas paralelas o unos junto a los otros, sino que cada relación léxica en una lengua sigue a la anterior; como, además, no se ofrece el nombre de cada animal en cada una de las lenguas, la consulta que persiga una información de equivalencias entre lenguas puede resultar fallida o dificultosa, lo cual podría paliarse recurriendo al apartado sobre denominaciones en los distintos idiomas existente en el artículo dedicado a cada animal. Esta estructura, por otra parte, no es exclusiva de Gesner, sino que se da también en las ediciones con lenguas modernas de la De medicinali materia de Pedacio Dioscórides Anazarbeo (como la de Amatus Lusitanus de 1553) y en sus versiones traducidas, como la titulada Acerca de la materia medicinal, y de los venenos mortiferos (Valencia, 1636), de Andrés de Laguna. Esta última, por ejemplo, contiene al final unas "Tablas Vniuersales de todos los nombres que en la obra presente segun varias lenguas, ocurren”, en las cuales, uno tras otro, se encuentran glosarios en griego, latín, árabe, latín de los boticarios, castellano, catalán, portugués, italiano, francés y alemán?

En la estela de Gesner, pero con un carácter divulgativo y didáctico y una temática más variada, se sitúa el Vocabulario del humanista (1569), de Lorenzo Palmireno. Dista muy mucho, no obstante, de ser tan rico en equivalencias políglotas como las obras de Gesner o Dioscórides, sobre todo en lo que atañe al francés: de sus nueve capítulos, solo en los dos primeros, sobre aves y peces, es realmente posible hallar equivalentes en francés u otra lengua de Francia para un cierto número, no demasiado elevado, de las entradas latinas y de sus correspondencias en castellano (y, a menudo, en valenciano, portugués o italiano) ${ }^{10}$.

Más interés tiene desde nuestra perspectiva otra obra que también hay que situar entre las de carácter erudito: De origine, usu, et ratione vulgarium vocum linguae Gallicae, Italicae, \& Hispanicae (París, 1583), de Jacques Bourgoing ${ }^{11}$. Se trata de un diccionario con las entradas en francés y equivalentes, tanto de esas entradas como de algunas voces francesas usadas en el interior de los artículos, en italiano y español, si bien estos equivalentes no aparecen sistemáticamente y son erróneos con frecuencia. Ahora bien, no se trata de un diccionario de equivalencias sin más, sino de un conjunto de comentarios diversos (etimológicos, históricos...), en latín, sobre cada vocablo y sobre las voces que el

\footnotetext{
9 Sobre Gesner o las diversas ediciones de la obra de Dioscórides, véanse Bajo Pérez (2000: 77-78), Breva Claramonte (2003: 91-92), Salas Quesada (2007).

${ }^{10}$ La aparición de correspondencias en otras lenguas para las entradas latinas no excluye siempre la existencia de una equivalencia castellana, como parecería deducirse de esta declaración del autor en el "Aviso" preliminar de su obra: "[...] si no hallo vocablo con que arromançar vna cosa en Castellano, pongola en Valenciano, Italiano, o Frances, o lengua Portuguesa".

${ }^{11}$ Sobre Bourgoing, véanse Gallina (1959:181-188), Finoli (1993), Bierbach (1995).
} 
autor percibe como relacionadas con él. La última entrada es la voz alum y la continuación prevista para la obra nunca vio la luz ${ }^{12}$.

Alguna otra obra de carácter filológico también presenta un listado de palabras españolas junto a un listado de palabras francesas; es el caso en el apartado "Voci overo vocaboli, che usano i Latini, Greci, Prouenzali, Francesi, Spagnuoli, Thedeschi, Englesi, Gothi, et altre nationi, delle quali noi non citiamo se non quelle, che piu si confermano, o confanno alla lingua nostra uolgare, et massimamente con le usate da gli approbati auttori, cioè Boccacio, Dante, et Petrarca", que ocupa los ff. $211 \mathrm{r}-222 \mathrm{r}$ de Le ricchezze della lingua volgare (Venecia, 1543), de Francesco Alunno. Pero, como se ve por el título del apartado, no es posible establecer aquí una correspondencia entre las voces del listado español y las del francés, sino que ambos listados, por lo demás con vocablos no coincidentes, se relacionan directamente solo con el italiano. Más interés puede presentar, en algunas ediciones de la Linguae Latinae exercitatio o Diálogos, de Juan Luis Vives, el índice final que reenvía a las palabras usadas en el libro. Únicamente en latín al salir de la mano de su autor, fueron añadiéndosele correspondencias en alguna otra lengua, dependiendo del lugar de publicación, e incluso en alguna edición, cual es la de Amberes 1552, un vocabulario en francés, alemán y español (Breva Claramonte 1994: 24-25 y, en este número de Philologia Hispalensis, Corvo Sánchez).

Pese al poliglotismo que domina la presencia conjunta del léxico francés y español en las obras del siglo XVI, ya se dio entonces algún caso excepcional de producción propiamente bilingüe francoespañola. La primera obra en el tiempo que revela una intención claramente lexicográfica exclusivamente en ese ámbito bilingüe es el Vocabulario de los vocablos que mas comunmente se suelen vsar. Puestos por orden del Abecedario, en Frances, y su declaracion en Español (Alcalá de Henares, 1565), debido a Jacques de Liaño, es decir, al francés Jacques Ledel, llegado a la corte española en el séquito de la reina Isabel de Valois. No puede decirse que Ledel hiciera una obra realmente original. Su librito es en realidad una versión bilingüe de la serie plurilingüe de los Berlaimont, lo cual explica su estructura: el vocabulario propiamente dicho aparece precedido de unas normas de pronunciación de ambos idiomas y seguido de unos diálogos. Dicho vocabulario presenta las entradas en francés y distribuidas alfabéticamente según su primera letra, si bien en cada grupo formado por las palabras con la misma letra inicial las entradas no siguen ni un orden alfabético ni un orden temático, lo que, ciertamente, no facilitaría la consulta rápida de algún vocablo preciso. Aunque basado en Berlaimont, como hemos dicho, este listado léxico no es un mero calco, sino que presenta una cierta

\footnotetext{
${ }^{12}$ No podemos considerar como propio de nuestro corpus, pese a su sugerente título, otro diccionario etimológico de finales del XVI: la Recopilación de algunos nombres arábigos, que los árabes (en España, Francia y Italia) pusieron a algunas ciudades y a otras muchas cosas (manuscrito, ca. 1593). Su autor, Diego de Guadix, no proporciona los equivalentes franceses de los vocablos españoles lematizados, pese a que sí los da a menudo en italiano (véase, por ejemplo, sobre). Ciertamente, algunas entradas son nombres castellanos que designan lugares franceses (Ardena, Secana, Sorbona...), pero el autor no proporciona su forma en francés. Del mismo modo, cuando alguna vez la entrada correspondiente a ese género de vocablos guarda su forma francesa (Ayne), no se encuentra en la definición ningún equivalente castellano, por lo que hay que entender que la forma de la entrada es considerada por el autor como la propia del español. Los pocos sustantivos comunes que aparecen en entrada y que se presentan como usados en el reino de Francia no nos resultan comprensibles: cirib, presentado como equivalente bretón de cama; xarra, presentado como equivalente de guerra.
} 
remodelación, con supresiones y añadidos de vocablos que le confieren cierto grado de independencia con respecto a su fuente principal (Acero Durántez 1998).

El Vocabulario de Ledel es la única versión de la serie Berlaimont editada en España en el siglo XVI. En su tiempo no tuvo ninguna reedición, como tampoco la tuvo la Grammatica de Baltasar de Sotomayor, otra obra publicada en el mismo año y por el mismo impresor con vistas a satisfacer la comunicación entre franceses y españoles en la corte madrileña. Grammatica y Vocabulario se vendieron en tiradas separadas, pero también bajo una misma encuadernación, como bien indica el título en la portada del conjunto: Grammatica con reglas muy prouechosas y necessarias para aprender a leer y escriuir la lengua Francesa, conferida con la Castellana, con vn vocabulario copioso de las mesmas lenguas. Curiosamente, más de setenta años después, en 1647, el impresor Antonio Lacavallería volvería a editar este conjunto de ambas obras en Barcelona, pero ya no al completo: además de no reimprimir algunos diálogos de Ledel, Lacavallería tampoco incluye el vocabulario propiamente dicho, o sea, el listado léxico francés-español, por lo que debe afirmarse que esta primera muestra lexicográfica bilingüe francoespañola solo conoció la edición de $1565^{13}$.

La primacía temporal que reconocemos al Vocabulario (1565) de Ledel en la lexicografía bilingüe que nos ocupa debe ser matizada: solo la tiene entre las obras impresas. Pero existe un vocabulario que nos ha llegado escrito a mano y que se le adelantó en el tiempo; se halla en el manuscrito 8431 de la Biblioteca Nacional de España, ff. 114r220r, entre un vocabulario español-italiano, que le precede, y otro español-vasco, que le sigue. Unidireccional español-francés, lleva por título, autor y año Dictionarium Linguae Franconiae, Año 1562. A Nicholaeo Landuchio ciuitatis Lucae Regionis Toscaniae vernaculae suae Linguae atque Franconiae Peritissimo ${ }^{14}$.

Para encontrar una nueva muestra de lexicografía bilingüe francoespañola hay que esperar al final del siglo, a 1599, año en que el Recueil de Hornkens abre la historia de los diccionarios bilingües francés-español propiamente dichos.

\section{SIGLO XVII}

El comienzo del siglo XVII representa también, en efecto, el verdadero inicio de la producción lexicográfica centrada en el español y el francés. En ese momento se hallaba a la venta el primer diccionario bilingüe con las dos lenguas que sea realmente merecedor de ese nombre: el Recueil o Recopilacion de Dictionarios Franceses, Españoles y Latinos, de Henricus Hornkens (Bruselas, 1599). Como toda obra inaugural, comporta aún ciertos signos de tanteo: por una parte, es unidireccional español-francés; por otra, incluye tras el equivalente francés de la entrada española un equivalente latino, lo cual podía contribuir a despejar cualquier duda en cuanto al sentido propio de la traducción francesa que se ofrecía.

\footnotetext{
${ }^{13}$ Sobre Ledel, véanse Flores (1978), Azorín Fernández (1985), Lépinette (1990a: 320-324), Corcuera \& Gaspar (1996: 178-186; 1999), Acero Durántez (1998), Bruña Cuevas (2000a: 64-67).

${ }^{14}$ Sobre Landuchio, véanse Michelena (1958), Gallina (1959: 121-130), Cundín Santos \& Líbano Zumalacárregui (2000: 311-312) y, en esta publicación, Echenique Elizondo.
} 
Tras este primer paso, pronto se dará el segundo: aparece en París, en 1604, el primer diccionario bilingüe y bidireccional español-francés y francés-español. Es el Diccionario muy copioso de la lengua española y francesa, compuesto por Jean Pallet. Pero esta obra, como la de Hornkens, tendrá una vida breve. Mientras que la Recopilacion de Hornkens nunca fue reeditada, el mismo año en que aparecía el segundo tomo de la segunda edición del Diccionario de Pallet, es decir, en 1607 (la segunda edición del primer tomo había aparecido el año anterior), otro editor parisino, Marc Orry, se lanza a la conquista del mismo mercado al que atendía la obra de Pallet; y lo hace, además, blandiendo un nombre de autor prestigioso al que ya le había editado varias obras: el de César Oudin ${ }^{15}$. Este último, además de ocupar el cargo de intérprete del rey para las lenguas francesa, española y alemana, era ya conocido en 1607 por el público que se interesaba por el castellano no solo como traductor de diversas obras literarias españolas, entre las que figura en lugar destacado la primera parte del Quijote (1605), sino como maestro de español (cf. Péligry 1987, Collet Sedola 1996, Souto Garrido 2002, Zuili 2006), con producciones como su Grammaire et observations de la langue Espagnolle (1597), que iba por su tercera edición en 1606, y sus Refranes o proverbios españoles traduzidos en lengua francesa (1605), conjunto completado desde 1608 con sus célebres Dialogos muy apazibles, escritos en lengua Española, y traduzidos en Frances. Esta producción didáctica, abundantemente reeditada, ejercerá una enorme influencia durante todo el siglo XVII en otros autores del mismo género de obras. Por todo ello, y pese a que Hornkens y Pallet se le adelantaran en la publicación de un diccionario bilingüe español-francés, el perfil de César Oudin se nos antoja como el más adecuado para llevar a cabo tal empresa ${ }^{16}$. No sorprende, pues, que sea su diccionario, su Tesoro de las dos lenguas francesa y española, el que finalmente se convierta en la obra lexicográfica de mayor prestigio durante el siglo XVII en el ámbito hispanofrancés. A ello contribuyeron tanto las varias reediciones de que fue objeto en París, Bruselas y Lyon a lo largo de la centuria cuanto la propia calidad de la obra original, acrecentada merced a la revisión de que fue objeto por su hijo, Antoine Oudin, en la edición parisina de 1645, así como gracias al gran número de nuevas entradas con que la enriqueció el propio César Oudin desde la segunda edición (París, 1616) por influencia del Tesoro de la lengua castellana o española (1611) de Sebastián de Covarrubias, del Bocabulario de germania incluido en los Romances de germanía (1609) de Juan Hidalgo (seudónimo de Cristóbal de Chaves) y del Tesoro de las tres lenguas francesa, italiana y española (1609) de Girolamo Vittori.

Esta última obra podría verse, si se juzgara solo por su título, como una vuelta al poliglotismo característico de la producción lexicográfica del siglo XVI, pero la realidad es que nada tiene que ver con las cartillas multilingües de orientación docente que proliferaron durante el XVI y seguirán haciéndolo durante el XVII. El Tesoro trilingüe de Vittori es, en

\footnotetext{
${ }^{15}$ Sobre los primeros diccionarios francoespañoles - los de Hornkens, Pallet o Oudin-, véanse Gili Gaya (1951), Cooper (1960a, 1960b, 1962), Verdonk (1979, 1989, 1990, 1992a), Sánchez Regueira (1982), Gemmingen (1986), Lépinette (1990a, 1990b, 2001: 95-188), Guerreros Ramos (1992: 468-471), Azorín Fernández (2000: 70-81), Martínez Egido (2002), Bruña Cuevas (2005a: 158-60; 2007)

${ }^{16}$ Jean Pallet era médico y se dedicó a componer su diccionario para rentabilizar una convalecencia de tres años en cama. El brabanzón Hornkens, por su parte, llevó una vida ajetreada; el haber sido enviado a España, al servicio de Alberto, poco antes de cumplir sus treinta años, explica su familiaridad con el español.
} 
efecto, un verdadero diccionario, y ello por la simple razón de que es fundamentalmente un plagio del de Oudin. En su primera edición de 1609, la obra se compone de dos partes: la primera es un diccionario con las entradas en español y las equivalencias en francés e italiano; la segunda presenta los lemas en francés con traducción al italiano y al español. El Tesoro de Vittori era, pues, el Tesoro de Oudin enriquecido con las equivalencias italianas, aspecto este último que apreciarían sin duda sus usuarios en una época en que el italiano, el francés y el español pasaban por ser las principales lenguas vivas de Europa.

En la historia de la lexicografía hispanofrancesa, el Tesoro de Vittori representa la entrada en liza, tras haberlo hecho Flandes y París, de otro potente centro de edición: Ginebra. Esa potencia explica, sin duda, que el diccionario de Vittori continuara siendo reeditado en esa ciudad hasta la misma década (los años setenta) del siglo XVII que el de Oudin, del que será por tanto un constante competidor directo. Tuvo que superar, eso sí, la acusación de plagio, con pruebas contundentes, que le lanza el propio César Oudin en el prólogo de la segunda edición de su Tesoro (1616), lo cual, como hemos dicho, no fue óbice para que Oudin mismo aumentara su obra con material tomado de Vittori. Los editores, tras la acusación, eliminaron de la portada, a partir de la edición de 1616-1617, el nombre de Vittori y la diseñaron de modo que pudiera aparecer en ella el de Oudin como una especie de auctoritas, al tiempo que acrecentaban la obra con un tercer volumen italiano-francés-español. Con su nueva configuración en tres tomos, la portada de la obra vuelve a atribuírsela a Vittori desde la reedición de $1637^{17}$.

El otro centro editorial, el de Flandes, repetirá unos años más tarde que el de Ginebra la misma operación de apropiación del diccionario de Oudin, aunque esta vez, dado el lugar de edición, la lengua añadida será el neerlandés en vez del italiano. Si Oudin había podido sacar provecho de la edición en Bruselas del diccionario de Hornkens, el editor Trogney, de Amberes, partirá del Tesoro de Oudin para componer El grande Dictionario y Thesoro de las tres lenguas Española, Francesa y Flamenca, salido en 1639. En los años siguientes lanzará nuevas tiradas cambiando la combinación de las lenguas. Tras la combinación de 1639 con las entradas en español y equivalencias en francés y flamenco, la combinación bilingüe francés-español llegará en 1640, todavía encuadernada en 1646 (sin cambio de fecha en la portada) con una combinación flamenco-español (que es la que lleva en portada la fecha de 1646) y otra español-francés-flamenco, correspondiente a la tirada de $1639^{18}$. El procedimiento recuerda sobremanera al que se seguía aún entonces con las series políglotas del género de la de Berlaimont, por más distancia que haya entre los listados léxicos de estas y los diccionarios de Trogney; de hecho, la familia Trogney había editado reiteradamente en el siglo XVI los Colloquia de la serie Berlaimont y, en ciertas tiradas del Dictionario de Amberes, este aparece acompañado de algún diálogo y de las conjugaciones verbales. En todo caso, como se comprueba por las fechas que acabamos de dar, esta competencia llegada al Tesoro bilingüe de Oudin desde Amberes fue menos persistente que la que ofreció el Tesoro trilingüe de Vittori desde Ginebra. Bien es verdad que, en gran

\footnotetext{
${ }^{17}$ Sobre el diccionario de Vittori, véanse Gallina (1959: 227-246), Cooper (1960a), Bruña Cuevas (2007), Pablo Núñez (2008b).

${ }^{18}$ Sobre este y otros diccionarios editados en Flandes, véanse Verdonk (1979: 311-318; 1988, 1989, 1998), Claes (2000), Dichtl (1998: 25-29), Bruña Cuevas (2005a: 161-164).
} 
medida, la apropiación por Trogney del Tesoro de Oudin no difiere demasiado (sobre todo en las tiradas bilingües francés-español) de la apropiación de la misma obra que llevaron a cabo algunos impresores de Bruselas en repetidas ocasiones a lo largo del siglo, con la diferencia de que, en Bruselas, el Tesoro apareció siempre con su título original y atribuido en portada a César Oudin; fue el caso en la edición de 1624-1625 por Hubert Antoine o en las de 1650 y 1660 por Jan Mommaert. De hecho, cuando aparezca por última vez el Tesoro de Oudin, ya no en París, sino en Lyon (1675), los impresores declararán basarse en la última edición de la obra realizada en Bruselas.

Puede decirse, en definitiva, que la obra de César Oudin, domina el panorama lexicográfico español-francés del siglo XVII ${ }^{19}$, si bien sometida a importantes revisiones, ya sea por el propio autor en su segunda edición (1616), ya por su hijo desde la edición parisina de 1645; y que, por razones de competencia comercial entre los impresores, fue apareciendo en diversas ciudades, con o sin ocultación del nombre de su autor, bien en versión bilingüe francés-español, bien en versión trilingüe con el italiano o el neerlandés. Como hemos dicho, el Tesoro, bajo el nombre de Oudin, se imprimirá por última vez en 1675, poco después, por tanto de la última edición del Tesoro de Vittori (1671). Ambos nombres, Oudin y Vittori, cederán desde comienzos del siglo XVIII, como veremos, ante la celebridad del de Sobrino.

Lo que acabamos de ver muestra un cambio esencial en el panorama lexicográfico español-francés, desde los primeros años del siglo XVII, con las obras de Hornkens, Pallet y Oudin. Pero ha de tenerse en cuenta que este cambio se produce, no por eliminación de los viejos usos lexicográficos, sino por incorporación de un nuevo tipo de obras llamadas a tener un desarrollo continuo y una presencia destacada en los siglos posteriores: los diccionarios bilingües español-francés y francés-español. Estos, por estar ordenados según lemas españoles o franceses, por su número de entradas, por la calidad de las equivalencias que ofrecen, por el nivel de formación de quienes los componen, por su entidad superior en cuanto productos de imprenta, por los usuarios a los que se destinan, se diferencian claramente de los vocabularios políglotas que dominaban prácticamente en solitario el campo lexicográfico hispanofrancés durante el siglo anterior, siendo en este sentido en el que decimos que hubo un cambio esencial en nuestro campo de estudio al llegar el siglo XVII. Ahora bien, no por ello hay que interpretar que se hizo tabula rasa de lo anterior. El cambio fue esencial, pero no radical; se produjo por incorporación de algo nuevo, pero no por eliminación de lo antiguo. Si los diccionarios de Pallet y Oudin son plenamente diccionarios bilingües bidireccionales, el de Hornkens, solo monodireccional, al incorporar equivalencia latinas aún parece inseguro en la nueva vía que emprende; por su parte, el Tesoro trilingüe de Vittori y el El grande dictionario de Amberes, aun estando más cerca de la innovación bilingüe que de la tradición políglota, no dejan de apostar por el camino tradicional de servir a más de dos comunidades lingüísticas, lo cual los acerca a las concepciones de los vocabularios plurilingües. Pero, sobre todo, lo antiguo, es decir, las

\footnotetext{
${ }^{19}$ Parece ser de inspiración independiente una obra que no llegó a salir a luz, pero que se ha conservado en los fondos de la Bibliothèque nationale de France: el Dictionnaire espagnol (en realidad, unidireccional españolfrancés), de Pierre Seguin, cuyo manuscrito cedió el autor a los carmelitas en 1636.
} 
tradicionales obras didácticas en que los diálogos y los rudimentos gramaticales en varias lenguas se completaban con un vocabulario igualmente políglota, mantiene todo su vigor a lo largo del siglo; así, desde los Países Bajos, Suiza, Italia, etc., se siguen lanzando al mercado los colloquia del tipo Berlaimont con vocabularios en seis, siete u ocho lenguas, combinadas de modo diverso según el lugar de impresión. También persisten, reiteradamente editados en Venecia, Lyon, Basilea y otras ciudades, los voluminosos calepinos de hasta once lenguas, y se mantiene asimismo durante el primer tercio del siglo la reedición, principalmente en territorio germánico pero también en Francia, del Nomenclator de Junius, con hasta ocho lenguas, y de la Sylva o Nomenclator de Decimator, publicado por última vez en 1606. Surgen incluso nuevas obras políglotas, tales como el Ductor in linguas (once lenguas con entradas en inglés; Londres, 1617) y el Vocabularium Hispanicum Latinum et Anglicum (entradas en español con equivalencias en latín e inglés, pero también, en las primeras letras, en italiano y francés; Londres, 1617), ambos de Minsheu y editados conjuntamente; o como el Lexicon Tetraglotton. Vocabulario EspañolInglès-Italiano-Francès (Londres, 1660), de Howell, un diccionario alfabético cuatrilingüe inglés-francés-italiano-español, seguido en el mismo volumen de una amplia nomenclatura temática, igualmente cuatrilingüe pero según el orden inglés-italiano-francés-español (Vocabulario particular, ô Nomenclatura Española, Inglese, Italiana, Francese, Londres, $1659)^{20}$. Son novedad asimismo el ambicioso Thesaurus polyglottus de Megiserus, que abre el siglo (Fráncfort, 1603; entradas en latín y correspondencias, irregularmente, en las más diversas lenguas), el Thesaurus linguae et sapientiae Germanicae de Henisch (Augsburgo, 1616; diccionario alemán-latín, letras A-G, con equivalencias en otras nueve lenguas) o el Gazophylacium decem linguarum europearum apertum de Warmer, con diez lenguas (Kosice, 1691). Cabe incluso citar el Thresor de la langue francoyse, tant ancienne que moderne (París, 1606) de Nicot, que puede considerarse como la quinta edición del Dictionaire francoislatin (París, 1539) de Robert Estienne, cuyo carácter bilingüe francéslatín se conserva, pero que da un gran paso adelante hacia el diccionario monolingüe en francés, al tiempo que, y es lo que más nos interesa ahora, ofrece para muchas palabras equivalencias en otras lenguas, entre ellas la española; nada que ver, sin embargo, en cuanto a la frecuencia de aparición de estas equivalencias multilingües, con la regularidad sistemática con que se ofrecen, por ejemplo, en el ya citado diccionario alemán-latín de Henisch.

Como hemos indicado que es el caso durante el siglo XVI en obras como Le ricchezze della lingua volgare de Francesco Alunno, también en el XVII hay algunas que incluyen listados léxicos en español y en francés, pero sin que se establezca una correspondencia directa entre las palabras que los componen. Así es, por ejemplo, en la Janua linguarum reserata quinque linguis, sive compendiosa methodus Latinam, Gallicam, Italicam, Hispanicam \& Germanicam linguam perdiscendi (Ámsterdam, 1661), la famosa obra didáctica de Comenio revisada por Duez: el número que acompaña a cada palabra de los índices finales (un índice por lengua) remite al número de página que la contiene en el libro, y solo leyendo el texto correspondiente se podría establecer una relación entre los

${ }^{20}$ Sobre Minsheu, véanse Gallina (1959: 247-260), Martín Gamero (1961: 93-96), Mary Joan (1962), Nieto (2000b: 215-216), Redondo Rodríguez (2006b). Sobre Howell, Sánchez Escribano (1978, 1983, 2008). 
términos españoles y los franceses ${ }^{21}$, hecho este que, evidentemente, aparta este tipo de obras de nuestro corpus lexicográfico o, por lo menos, las sitúa en los márgenes. Y son también listados independientes los que incluyen las reediciones del XVII de obras como las de Dioscórides o Gesner, de las que ya nos hemos ocupado, si bien, en estos casos, al ir a buscar una palabra en el contenido del libro a partir del índice, lo que puede encontrar el lector es un apartado sobre los nombres que recibe en diferentes idiomas el referente de la palabra en cuestión, por lo que estas obras resultan de mayor interés para nuestro estudio. Lo mismo ocurre con los tratados sobre los distintos órdenes de animales que, según un modelo similar al de Gesner, compuso Ulisse Aldrovandi y que se editaron y reeditaron en Bolonia desde 1599: los listados léxicos de cada lengua situados al final de los volúmenes remiten al artículo correspondiente, donde es posible encontrar a veces la denominación en español y francés, además de en otras muchas lenguas antiguas y modernas, del animal de que se trata. Los listados o índices de, por ejemplo, el primer volumen (Ornithologiae, hoc est de Auibus historiae libri XII, 1599), llevan el título de "Index superiorum duodecim ornithologiae librorum locupletissimus, Latinus, Graecus, Hebraicus, Arabicus, Persicus, Aegyptiacus, Indianus, Italicus, Gallicus, Hispanicus, Germanicus, Belgicus, Anglicus, Polonicus, Moscouiticus, Illyricus, Turcicus"; y, por tomar otro ejemplo de otro volumen de la obra, en la Quadrupedum omniu[m] bisulcoru[m] historia (1621), al tratar sobre el buey se lee (p. 35), en el apartado "Nomina aliarum nationum", lo siguiente: "A bue, alicubi etiam tamen, vt apud nos bó, Galli buef, Hispani buey, Germani ochs \& rind, Belgis os, Angli ope, fortè quasi opera, aut opes, ob allatä saepe rationem: Illyrijs Vvul". Inmediatamente después se da también un listado con las mismas lenguas para los nombres del toro y de la vaca.

Ahora bien, en el ámbito de la producción sobre el mundo natural, la obra que debemos destacar por su interés lexicográfico para nuestro estudio es la compuesta por Miquel Agustí, el Libro de los secretos de agricultura, casa de campo y pastoril. Aparecido por primera vez en catalán (Barcelona, 1617), todas sus reediciones posteriores, a lo largo de los siglos XVII y XVIII, fueron en castellano, siendo la primera salida en esta lengua la de Perpiñán de 1626 o, si existió, la de Zaragoza de 1625. El propio autor incorporó a su versión castellana un vocabulario relativo a la materia tratada en la obra: la "Declaracion del vocabulario que se sigue en seys Lenguas, de los nombres de los Árboles, yeruas, frutas, y otras cosas contenidas en el presente Libro de los secretos de Agricultura". Es un listado de vocablos en que el orden alfabético va establecido conforme a las entradas en castellano, las cuales se sitúan en columna seguidas de equivalentes en catalán, latín, portugués, italiano y francés ${ }^{22}$.

Una observación se impone sobre todas estas obras políglotas que venimos comentando: no son obras dirigidas en particular a hispanohablantes y francófonos conjuntamente. En todas ellas se encuentran, con mayor o menor dificultad, equivalencias en español y en francés para un mismo lema, pero, a diferencia de los nuevos diccionarios bilingües

\footnotetext{
${ }^{21}$ Sobre Comenio, véanse Caravolas (1991), Pensado (1987), Inclán García-Robés (1990), Martín Mingorance (1994: 23-24), Besse (2001), García Aranda (2003: 133-139; 2005), Rueda Rueda et alii (2004).

${ }^{22}$ Sobre Agustí, véanse Colón \& Soberanas (1986: 100-102), Messner (1993: 85-109), Rico \& Solà (1995: 101102).
} 
francoespañoles que alumbra el siglo y a los que nos hemos referido, la lengua de entrada casi nunca es el castellano y pocas veces el francés. Tres tan solo son las excepciones a este respecto en lo que se refiere al castellano. Una es el Vocabularium (1617) de Minsheu, publicado, como hemos visto, en Londres y principalmente atento a establecer las correspondencias español-inglés, en cierto modo como complemento al Ductor, con el cual se editó encuadernado y cuyas entradas estaban en inglés. Las otras dos nos parecen más significativas aún por haber sido editadas en España. La primera es El libro de los secretos de Agustí, que acabamos de comentar. La segunda es la adaptación trilingüe españolfrancés-catalán de los Colloquia cum dictionariolo de la serie Berlaimont por el impresor Lacavallería, es decir, su Dictionario Castellano - Dictionaire François - Dictionari Catala. Esta adaptación es la única de esa serie que se imprime en España, concretamente en Barcelona, durante el siglo XVII; de ahí que sea también la única que presente en español las entradas del vocabulario propio de la serie y la única que ofrezca equivalentes en catalán. Las equivalencias francesas se sitúan entre las voces castellanas y las catalanas. Aparecida en 1642, con nueva edición en 1647, esta inusual adaptación del Berlaimont ${ }^{23}$ se explica por la situación política y militar en que se hallaba por aquel tiempo Cataluña, con la mayor parte de su territorio bajo soberanía de la corona de Francia ${ }^{24}$.

El trilingüismo con la lengua vasca no dio lugar, en cambio, al mismo resultado lexicográfico que el trilingüismo con el catalán. No se presentan emparejadas, en efecto, las lenguas española y francesa en L'interprect ou Traduction du François, Espagnol \& Basque (Lyon, ca. 1620), de Voltoire, ni en las varias reediciones de esta obra aparecidas en Bayona en 1642 y 1684 bajo el título de Thresor des trois langues, Francoise, Espagnolle, et Basque. A pesar del carácter trilingüe de esta cartilla en lo que atañe a su contenido gramatical y sus diálogos, el vocabulario que incluye en 1620 y 1642 es solo francés-vasco y desaparece de la edición de 1684. Hay que esperar a las reediciones sin fecha lanzadas en los primeros años del siglo XVIII para que la obra incorpore una nomenclatura temática español-francés ${ }^{25}$. Tal vez si Dominique Bidegaray, muerto en 1679, hubiera obtenido la subvención oficial que solicitó, hubiera visto la luz su diccionario cuatrilingüe vasco-latín-francés-español; al no obtenerla, tampoco ha sobrevivido su obra. Pero sí han llegado hasta hoy dos diccionarios manuscritos de Sylvain Pouvreau, uno vasco-francés y otro latín-castellano; quizá su intención, como se ha sostenido, fuera el de elaborar una obra políglota con las cuatro lenguas.

\footnotetext{
${ }^{23}$ Las dos impresiones barcelonesas del Dictionario trilingüe y la edición complutense del Vocabulario bilingüe de Ledel (1565), del que ya nos hemos ocupado, son las únicas representantes de la serie Berlaimont aparecidas en España.

${ }^{24}$ Sobre Lacavallería, véanse Colón \& Soberanas (1986: 102-104), Sáez Rivera (2005), García Bascuñana (2008), Bruña Cuevas (en prensa).

${ }^{25}$ Sobre Voltoire, véanse Videgain (2000), Sáez Rivera (2006, 2007: 250-262). Sobre lexicografía plurilingüe con el vasco, véanse Echenique Elizondo (1998, 2008).
} 
Si los diccionarios bilingües español-francés se desarrollan desde comienzos del siglo XVII, no menor desarrollo alcanzan las nomenclaturas o vocabularios en esas dos mismas lenguas organizados por campos temáticos. Estas nomenclaturas bilingües, como las políglotas, aparecen incluidas a menudo, por su fuerte orientación didáctica, en obras destinadas a la enseñanza del español. La proliferación en el XVII de estas últimas es pues, en gran medida, origen de la multiplicación de aquellas. Por el contrario, las gramáticas del francés salidas a luz en España no incluyeron en ningún caso una nomenclatura durante este siglo: no lo hacen ni el Arte de gramática francesa en español (Madrid, 1635) de Cisneros, ni la Gramática francesa (Zaragoza, 1673) de Billet, ni el Arte [...] de la lengua francesa por la española (Madrid, 1688) de Jaron. Se repite así, también en este ámbito, la escasez de producción lexicográfica francés-español editada en la Península que ya habíamos comprobado al hablar de los grandes diccionarios.

En este campo de las nomenclaturas, como en el de los diccionarios bilingües, vuelve a destacar la producción de César y Antoine Oudin. César Oudin, en efecto, añadió a sus Dialogos muy apazibles, escritos en lengua Española, y traduzidos en Frances (París, 1608), desde la reedición parisiense de 1622, un "Nomenclátor o registro de algunas cosas curiosas y necesarias de saberse en los estudios de la lengua española", presente en las varias reediciones que luego tuvo la obra hasta 1675 . Es lo más probable que Oudin, al componer este "Nomenclátor", ya conociera dos nomenclaturas anteriores: la incluida por Lorenzo de Robles en su Advertencia y Breve método (París, 1615) y la incluida ${ }^{26}$ por Alejandro de Luna en su Ramillete de flores poéticas (Toulouse, 1620) ${ }^{27}$. Parecen de concepción propia los listados temáticos incluidos por Ambrosio de Salazar en su Espejo general de la gramática (Ruán, 1614), pero es muy probable, en cambio, que esté basada en el nomenclátor de César Oudin la relación de "Miembros del cuerpo humano", incorporado por Jerónimo de Tejeda a su Méthode de español (París, 1629). No parte de César Oudin, en cambio, pese a lo que hubiera podido esperarse, la Nomenclature Françoise et Espagnole (París, 1647) de Antoine Oudin, obra más compleja en su género que la de su padre y que las de los otros autores, de las cuales se distingue, además, por el orden de las lenguas: aunque también es unidireccional, no lo es en el orden españolfrancés como las anteriores, sino en el orden francés-español. También apareció en 1647, en Colonia, la Instruction Espagnole de Marcos Fernández, con inclusión de un nomenclátor bilingüe español-francés, viendo todavía la luz en Francia, ya durante la segunda mitad del siglo, las nomenclaturas de Claude Dupuis (en La Grammaire Espagnole, París, 1659) y la de Ferrus (en Nouvelle grammaire espagnole,

\footnotetext{
${ }^{26}$ Alejandro de Luna incorpora en realidad dos listados léxicos a su Ramillete (pp. 121-144), ambos con la dirección español-francés. El primero es alfabético (aunque solo se tiene en cuenta para la ordenación que las palabras empiecen por la misma letra, sin tomar en consideración las siguientes letras que las componen) y el segundo temático.

${ }^{27}$ Se han invocado las similitudes entre las nomenclaturas de C. Oudin, L. Robles y A. de Luna para suponer una influencia del primero sobre los otros dos. Para ello se parte de que existió una edición de los Diálogos de Oudin con fecha de 1604 que incluía el nomenclátor. Ahora bien, en esa edición bruselense aparece como impresor Fr. Foppens, quien, sin embargo, no empezó su labor hasta 1637, siendo cierto, eso sí, que editó los Diálogos en la segunda mitad del siglo. La fecha de 1604 que aparece en la portada de tal edición se deberá por tanto a una errata o a una manipulación editorial. Ya Foulché-Delbosc (1962 [1912-1914]) llamó la atención sobre esta anomalía, como bien lo ha recordado recientemente García Aranda (2003: 115).
} 
Ámsterdam/Lyon, 1680), derivadas de la de César Oudin, pero presentadas en el orden francés-español ${ }^{28}$. Mención aparte merece el Vocabulario de François Huillery (París, 1661), monodireccional español-francés, pero dispuesto, no por orden temático, sino por orden más o menos alfabético y enriquecido con frecuentes definiciones y jugosos comentarios; en él, además, como en la Nomenclature de Antoine Oudin pero contrariamente a los demás libros a los que acabamos de aludir, es el vocabulario el que constituye el grueso de la obra ${ }^{29}$.

Hubo igualmente en el XVII vocabularios temáticos políglotos en que no siempre el español o el francés ocupaban la primera posición, si bien tal circunstancia es de importancia secundaria en este tipo de obras, contrariamente a lo que es el caso en los vocabularios o diccionarios organizados alfabéticamente. Ya hemos consignado las obras de Junius y Howell. Cabe citar igualmente dos nomenclaturas trilingües italiano-francésespañol: la de Guillaume-Alexandre de Novilliers Clavel (Venecia, 1629) y la de BlaiseChristophe Julliani (París, 1659); si la primera es en gran parte original e inspiró fuertemente la obra de Howell, la segunda siguió el modelo temático de César Oudin, directamente y a través de la adaptación llevada a cabo por Franciosini, sirviendo luego de base, junto con la de Dupuis, a la ya mencionada de Ferrus. Mayor número de lenguas comprenden, debido al ámbito territorial germánico en que ejercía su profesión docente el autor, los listados lexicográficos de Juan Ángel de Sumaran: la "Nomenclatura en quatro lenguas" (francés-italiano-español-alemán) -que conforma la tercera parte de su Libro muy prouechoso para aprender las lenguas (Múnich, 1621)- y la pentalingüe latín-italianofrancés-español-alemán, que es la tercera parte de su Thesaurus fundamentalis (Ingolstadt, $1626)^{30}$.

\section{SIGLO XVIII}

En el ámbito de los diccionarios, es decir, de las obras lexicográficas bilingües francésespañol de gran envergadura ${ }^{31}$, la continuidad con respecto al siglo XVII vendrá asegurada por la publicación, a comienzos de siglo (1705), del Dicionario nuevo de las lenguas española y francesa, de Francisco Sobrino, sobradamente inspirado del Tesoro de Oudin. Sobrino, en efecto, lleva a cabo una labor muy similar a la realizada por César Oudin un siglo antes. Como en el caso de este, su Dicionario se inserta en un conjunto de obras

\footnotetext{
${ }^{28}$ Sobre los Diálogos de C. Oudin, véase Lépinette (1991) y, sobre la nomenclatura que contienen, García Aranda (2003: 115-118). Se hallará información sobre Robles en Alvar Ezquerra (1997a); sobre A. de Luna, en FaliuLacourt (1982) y Alvar Ezquerra (1997b); sobre el Espejo de Salazar, en Muñoz Garrigós (1996); sobre la Nomenclature de A. Oudin, en Quemada (1968: 365-366) y Ayala Castro (1992: 139-140); sobre Dupuis, Ferrus y Fernández, en Sáez Rivera (2007: 282-294, 359-367, 885-898).

${ }^{29}$ Sobre Huillery, véanse Gemmingen (1993), Pablo Núñez (2006) y Sáez Rivera (2007: 346-359).

${ }^{30}$ Sobre Novilliers, véanse Gallina (1959: 293-302), Ayala Castro (1992:138-139), García Aranda (2003: 129 131) y Castillo Peña (2006). Sobre Julliani, García Aranda (2003: 145-147) y Sáez Rivera (2007: 316-321). Sobre Sumaran, véanse Suárez Gómez (1956: 92-95), Gallina (1959: 285-292), Ayala Castro (1992:137-138), Bruña Cuevas (2000a: 67-73), García Aranda (2003: 126-129) y Corvo Sánchez (2005, 2007b, 2008).

${ }^{31}$ Además de en algunos estudios que abarcan varios siglos (véase nuestra nota 2), se encontrará un panorama comentado de la lexicografía francoespañola del siglo XVIII en Niederehe (1988).
} 
destinadas a facilitar a los francófonos el acceso al español. Ya en 1697 había publicado en Bruselas su Nouvelle grammaire espagnole, continuamente reeditada a lo largo del siglo XVIII y, más o menos adaptada, durante todo el siglo XIX hasta llegar a principios del XX. También publica sus Diálogos nuevos en español y francés (Bruselas, 1708), igualmente reeditados hasta comienzos del XIX. Y este conjunto didáctico, salido de la imprenta bruselense de François Foppens, se completará en 1720 con el Secretario Español enseñando la manera de escrivir cartas españolas, segun el estilo moderno, esplicadas en Francès, con reediciones que llegan hasta mediados de la centuria. El nombre de Sobrino, durante dos siglos, quedará así indisolublemente asociado en el ámbito francófono al aprendizaje del castellano.

En la concepción de estas varias obras como un conjunto didáctico global radica el que una particularidad del diccionario de Sobrino en su primera edición desaparezca de las ediciones siguientes; nos referimos a la inclusión, al final del tomo segundo de la edición de 1705, de una "Méthode facile pour apprendre la langue espagnole; par l'arangement des mots selon la construction de l'univers, avec les principaux termes des Arts et des Sciences", es decir, una nomenclatura temática francés-español orientada, como indica su título, a la adquisición sistemática del vocabulario español. Dado que el autor publica sus Diálogos en 1708 y que incorpora a ellos un "Nomenclator de algunas cosas curiosas y necessarias de saver", de igual título que el que había incluido César Oudin en sus Diálogos (es la fuente principal de Sobrino, junto con la nomenclatura de Pomey), la "Méthode" del Dicionario nuevo de 1705 no tenía ya razón de ser cuando este es reeditado por segunda vez en 1721, por lo que no que no se incluye ni entonces ni en las ediciones posteriores ${ }^{32}$.

Como ya hemos señalado que le ocurrió al Tesoro de Oudin, el Dicionario de Sobrino también subsistió gracias a un cambio de lugar de edición. Aunque en origen salido en Bruselas, acabará dependiendo de Ginebra desde su cuarta edición de 1744, es decir, desde que el impresor Henri-Albert Gosse lo tomó a su cargo, por más que siguiera siendo Bruselas la ciudad que figurase en portada (Bruña Cuevas 2008b). No obstante, la obra, pese a mantener su renombre hasta mucho tiempo después, no volverá a imprimirse después de su sexta edición de 1760. Otros autores y otros centros editoriales tomarán el relevo.

La asentada presencia en el panorama lexicográfico francoespañol del diccionario de Sobrino durante la primera mitad del siglo no se vio afectada por la principal novedad que, en este ámbito, aportó el siglo XVIII: la publicación en Madrid de diccionarios propios de nuestro corpus. Contrariamente a lo que hemos visto para los siglos XVI y XVII, tres diccionarios francés-español saldrán de la imprenta en España durante el Siglo de las Luces, concretamente en los algo más de treinta años que median entre 1728 y 1761, lo que no deja de ser sorprendente, tanto si se mira hacia el pasado como si se mira hacia la segunda parte de la centuria. Ninguno de ellos, sin embargo, logró alcanzar una segunda

\footnotetext{
${ }^{32}$ Sobre la vida y el conjunto de la obra de Sobrino, véase Sáez Rivera (2002, 2007: 369-455). Sobre su Tesoro, véanse Verdonk (1979: 332-341; 1992b, 1994), Supiot (1991), Puche Roca (1996), Cazorla Vivas (2002a: 53-97; 2002b), Bruña Cuevas (2005a: 165-166).
} 
edición, en parte por la debilidad comercial de los impresores madrileños, en parte por las deficiencias propias de las obras mismas ${ }^{33}$.

El primero de estos diccionarios fue El Maestro de las dos Lenguas (1728-1731), de Francisco de la Torre y Ocón, obra que en modo alguno puede verse como un plagio del competidor con el que debía medirse, el Sobrino. Con respecto a este, es algo más simple, lo que pudo representar una facilidad de manejo para algunos usuarios. En todo caso, siendo una obra póstuma, solo editada gracias al apoyo de un mecenas, y compuesta con anterioridad a la edición del Diccionario de la lengua castellana (1726-1739) de la Real Academia Española, que por ende no pudo serle de provecho a Ocón para aumentar el caudal léxico de su obra, el Maestro tenía pocas posibilidades de renovar su salida al mercado, sobre todo después de la reedición por tercera vez (1734) del diccionario de Sobrino, que sí empezaba a promocionarse aludiendo en portada al Diccionario de la Academia y que, sobre todo, conservaba todo su prestigio y todo el empuje comercial de los Foppens.

Fue de planteamientos novedosos en la historia de la lexicografía bilingüe el Diccionario universal (1743-1744) de Antonio María Herrero. En vez de partir de los anteriores diccionarios bilingües para establecer sus entradas francesas, Herrero partió de un diccionario monolingüe de carácter enciclopédico: el conocido como Dictionnaire de Trévoux, es decir, el Dictionnaire universel françois et latin, publicado por primera vez en Trévoux, en 1704, y posteriormente varias veces reeditado. En ello, Herrero fue un precedente precoz de los lexicógrafos del siglo XIX, tales como Domínguez o Fernández Cuesta, que también buscaron su fuente en los diccionarios enciclopédicos monolingües franceses de su tiempo. El carácter innovador del diccionario de Herrero quedó empañado, sin embargo, por varias circunstancias. Por un lado, la riqueza en lemas de su fuente era prácticamente imposible de trasladar en su época a un diccionario bilingüe, máxime cuando ni siquiera se disponía aún de un diccionario monolingüe español de términos de las artes y las ciencias; el autor tomó, pues, la decisión de reservar tales voces para un futuro suplemento, que desdichadamente nunca vio la luz. Por otro lado, Herrero adoptó para la ortografía de sus lemas la misma convención que halló en el Trévoux: la de escribirlos en letras mayúsculas salvo las letras no pronunciadas, transcritas en minúsculas: COsTELEtTE. Solo que su obra aparece precisamente cuando el Trévoux, en su cuarta edición de 1743, abandona los criterios ortográficos de sus ediciones anteriores para asumir la nueva ortografía simplificada adoptada por la Academia Francesa en la tercera edición de su Dictionnaire (1740), con lo que el bilingüe de Herrero resultaba anticuado en esta materia desde el mismo momento de su aparición. Si a todo ello se añade que la obra de Herrero era unidireccional francés-español y que en 1744 aparece también una nueva edición revisada del Sobrino, desde siempre bidireccional, no sorprende que fuera esta última obra la que siguiera gozando del favor general y que la madrileña no volviera a reimprimirse.

Todavía, como hemos dicho, hubo una tercera tentativa dieciochesca de lanzar desde España un diccionario francoespañol: la del Diccionario general (1761-1763) de Nicolás

${ }^{33}$ En relación con esos tres diccionarios, véanse Cazorla Vivas (2002a: 101-134, 177-192; 2002-2004, 2008) y Bruña Cuevas (2006a). 
Gonzalez de Mendoza. Bilingüe bidireccional, contrariamente al de Herrero, y fuertemente influenciado por el de Sobrino, González de Mendoza busca simplificarlo en lo posible, poniéndose como meta el conseguir la mayor univocidad posible en las correspondencias entre las dos lenguas. Meta inalcanzable, esta pretensión lleva a veces al autor a consignar un simple "No hay" donde debiera estar la correspondencia para el lema. Un diccionario así recuerda en sus pretensiones lo que intentarán alcanzar un día los diccionarios de bolsillo más simplificados, solo que este no presenta aún tal formato, por lo que tampoco por ahí podrá competir con el nuevo diccionario en gran formato que se lanza por entonces desde los grandes centros difusores europeos, desde París esta vez: en 1759 había aprecido el Nouveau Dictionnaire Espagnol-François et Latin, composé sur les dictionnaires des Académies Royales de Madrid et de Paris, de Pierre de Séjournant.

El diccionario de Séjournant presenta la novedad, como indica su título, de ser realmente el primero cuya parte español-francés fue compuesta desde el principio siguiendo de cerca al Diccionario de la Real Academia Española, tanto en su macroestructura como en las definiciones que acompañan o sustituyen a las equivalencias en su microestructura. Hasta la novedad de incorporar en esta parte español-francés (no así en la parte francésespañol) los equivalentes latinos se debe seguramente a esa misma inspiración en el Diccionario de Autoridades, que los proporcionaba para el español; recuérdese que el último diccionario francoespañol en adjuntarlos había sido el Recueil (1599) de Hornkens. La influencia del de Autoridades se detecta incluso en la parte francés-español, junto a la del Dictionnaire de la Academia Francesa y a la del Trévoux. Cuando, en 1780, la Real Academia Española lance su nuevo modelo de diccionario, el cambio se dejará igualmente sentir en las nuevas ediciones del bilingüe de Séjournant, por entonces ya fallecido.

El academicismo de que hacía gala el Séjournant y la renovación real que introdujo con respecto al ya histórico Sobrino debieron de desempeñar un papel relevante en la fama que llegó a adquirir. Pronto, sin embargo, tuvo que afrontar la competencia ginebrina. Los hermanos De Tournes, libreros de Ginebra y Lyon, lanzan una operación de apropiación de la nueva obra: editan un diccionario francoespañol bidireccional compuesto por François Cormon, con Amberes como ciudad de edición en portada y con un título que recupera en su provecho la popularidad del nombre de Sobrino: Nouveau dictionnaire de Sobrino, François, Espagnol et Latin / Sobrino aumentado o Nuevo Diccionario de las Lenguas Española, Francesa y Latina (1769). Se trata en realidad de una impresión ligeramente retocada de la obra de Séjournant. Su principal añadido no es, de hecho, sino el de las correspondencias latinas también en la parte francés-español.

Gracias al diccionario de François Cormon el nombre de Sobrino seguirá resonando como referencia lexicográfica hasta finales del XVIII, al igual que resonaba como referencia gramatical para el aprendizaje del español por los francófonos; de hecho, no son pocos los catálogos bibliográficos o bibliotecarios que aún hoy atribuyen la obra de Cormon a Francisco Sobrino. Las reediciones del Sobrino aumentado, en efecto, competirán desde su aparición, durante treinta años, con las que fueron saliendo en París del Nouveau dictionnaire de Séjournant, hasta que, por cambios en las casas editoras respectivas, uno y otro sean impresos por última vez en Lyon, al comenzar la década de los 
noventa, por Delamollière ${ }^{34}$. Para entonces, ambos habían superado sin ningún problema la competencia del diccionario de González de Mendoza (1761-1763), pero no sobrevivirán, pese a las críticas que la edición de 1791 del Sobrino aumentado lanza contra él, al nuevo diccionario bilingüe salido el año anterior también en Lyon: los sucesos revolucionarios darán lugar a la ejecución de Delamollière en 1794 y al final consiguiente de su tarea impresora. Con él fenecerá también, como acabamos de decir, la última versión de los dos diccionarios francoespañoles más presentes hasta entonces en el mercado ${ }^{35}$.

El sustituto de ambos será el Nouveau dictionnaire espagnol et françois, françois et espagnol, avec l'interprétation latine de chaque mot (Lyon, 1790), de Claude-Marie Gattel. Partía del diccionario de Séjournant al igual que el Sobrino aumentado, pero sin llegar a ser una copia tan cercana a su fuente común como lo fue este último, a pesar de que, como en el Séjournant, las equivalencias latinas solo aparecen en la parte español-francés, y no en las dos partes como en el diccionario de François Cormon. Pero, contrariamente a Séjournant, en la parte francés-español Gattel ofrece las definiciones que acompañan frecuentemente en estos diccionarios a las equivalencias de los lemas, no en francés, como incongruentemente hacía su modelo, sino en español. Habrá que esperar trece años para ver editado el Gattel por segunda vez (1803), muy seguramente porque los sucesos revolucionarios también afectaron gravemente a la empresa y la vida de los hermanos Bruyset, editores de la obra, y al propio autor. Así pues, que este diccionario volviera a salir a la luz, mientras que los de Séjournant y Cormon no aparecieron más después de 1791, puede no ser debido sino a un puro envite de la suerte en la tormenta revolucionaria a favor de unos impresores y en contra de otros.

Gattel es el verdadero promotor, en el ámbito de la lexicografía francoespañola, de los diccionarios en formato pequeño, gracias a su Nuevo diccionario portátil español y francés, aparecido en 1798 tanto en París, lanzado por los libreros Bossange, Masson y Besson, como en Valencia, debido a la relación que mantenía la casa valenciana de Mallén con la parisina de Bossange. El cambio de formato y la remodelación consiguiente de la obra responden a la necesidad de abaratar costos que se deja sentir a finales del siglo XVIII: la propia Real Academia abandona la reedición de su Diccionario de Autoridades, comenzada en 1770, y lanza una versión de su obra reducida a un solo volumen (1780). Los portátiles y el uso en los diccionarios de caracteres de menor tamaño que permitían ahorrar papel se extendían, de hecho, por toda Europa. Con todo, no es la de Gattel la primera obra de nuestro corpus que se proclama como un diccionario portátil; el primero fue el editado tres años antes por Diego Antonio Godoy: el Diccionario nuevo portátil y manual francésespañol (1795). Pero, salido a luz en Bolonia, su publicación pasó inadvertida para los

\footnotetext{
${ }^{34}$ No es de extrañar que Delamollière llegara a publicar los dos diccionarios. Delamollière se había encargado de la edición de 1789 del Sobrino aumentado de François Cormon; lo había editado junto con Piestre, quien previamente había colaborado con François Cormon, que también estaba en el negocio editorial, para, por ejemplo, comprar el fondo latino de la casa De Tournes, editora de la obra de Séjournant. Pero Piestre, ante el cariz que tomaban los acontecimientos revolucionarios, cedió sus fondos a Delamollière, lo que explica que este aparezca como único impresor de ambos diccionarios desde 1790.

${ }^{35}$ Sobre los diccionarios de Séjournant y F. Cormon, véanse Cazorla Vivas (2002a: 137-175, 193-243; 2002c), Bruña Cuevas (2005a: 166-169).
} 
siguientes autores, contrariamente a lo que fue el caso del diccionario de Gattel, reeditado (1806) en vida del autor y varias veces contrahecho tras su muerte.

La competencia entre las casas lionesas por el mercado de los diccionarios bilingües que nos ocupan dio lugar a la edición, en 1800, de otro más en esa ciudad. El apellido de su autor, Jacques Louis Barthélemy Cormon, no es nuevo en nuestra historia; se trata del nieto de François Cormon, autor del Sobrino aumentado, ya partícipe, como su descendiente, en el negocio de librería: también el Diccionario portátil y de pronunciacion, español-frances y frances-español de Barthélemy Cormon está editado por el propio autor-librero junto con Blanc y Reymann ${ }^{36}$.

El Diccionario portátil de Cormon es en gran medida una versión resumida del Nouveau dictionnaire espagnol et françois de Gattel, de quien toma también la idea de lanzar su obra en pequeño formato, a medio camino, no obstante, entre la versión gran formato y la versión de bolsillo de Gattel. Cormon elimina las equivalencias latinas que ofrecían las grandes producciones lexicográficas francoespañolas editadas fuera de España desde que las incluyera Séjournant. En tal supresión será seguido por todos los autores de nuestros diccionarios bilingües del siglo XIX, con las salvedades que indicaremos más adelante. Por el contrario, la otra y principal innovación de Cormon tendrá menor fortuna a corto y medio plazo; nos referimos a la incorporación de la pronunciación figurada correspondiente a la mayor parte de los lemas franceses y españoles (Bruña Cuevas 2000b, 2002, 2005b).

La emulación entre los autores y los editores de los diccionarios de Gattel y Cormon dio lugar a una nueva edición lionesa de sus respectivos diccionarios, en cuyos prefacios estalla vivamente la rivalidad. Gattel lanza esa segunda edición en 1803 y en ella, además de presentar el diccionario de Cormon como un plagio del suyo, reconoce como buena la idea de incluir la pronunciación figurada de cada lema, lo cual lleva a cabo pero proponiendo un sistema de notación diferente al de Cormon, un sistema inspirado del que el propio Gattel ya había incorporado a su diccionario monolingüe del francés (Nouveau dictionnaire portatif de la langue françoise, Lyon, 1797). También da por buena, y añade a su obra, otra de las novedades aportadas por Cormon a la lexicografía bilingüe: la de ofrecer un listado de las palabras puestas en circulación por los cambios políticos vividos por Francia en los últimos decenios del XVIII. En realidad, como es el caso de la pronunciación figurada, también ese listado aparecía ya en el diccionario monolingüe de Gattel al que nos hemos referido (1797), así como en la quinta edición del Dictionnaire de l'Académie Françoise (1798), por lo que Gattel veía como natural el adaptarlo a la segunda edición de su diccionario francoespañol. La reacción de Cormon solo se hizo esperar unos meses: ese mismo año de 1803 salía a luz, como hemos dicho, la segunda edición de su Diccionario portátil, con el correspondiente prólogo de respuesta airada contra el de Gattel.

\footnotetext{
${ }^{36}$ Sobre los diccionarios de Godoy, Gattel y Cormon, véanse García Bascuñana (1999), Bruña Cuevas (2000b, 2005a:169-71), Gemmingen (2001), Cazorla Vivas (2002a: 263-310; 2002d, 2006a).
} 
Todavía hubiera podido ser mayor el número de diccionarios francés-español publicados en el siglo XVIII si hubieran llegado a imprimirse dos obras compuestas en el primer cuarto del siglo. Una de ellas es el Diccionario de las dos lenguas espanyola, y francesa, que data de 1718 y se conserva manuscrita en la biblioteca del Centre de Lectura de Reus; aunque anónima, se debe seguramente a un autor catalonohablante, ya que está acompañada en el manuscrito de un Methodo per encontrar ab facilitát lo arreglament de varios y differents vocables segons la construcció del Univérs, ab los principals termes dels arts, y ciencias, es decir, de una nomenclatura catalán-francés inspirada de la nomenclatura español-francés de similar título (Methode facile pour apprendre la Langue Espagnole: Par l'arangement des mots selon la construction de l'Univers, avec les principaux termes des Arts et des Sciences) que se incluye en la primera edición del Sobrino (1705), diccionario que sirve también de modelo para la primera parte de la obra del anónimo catalán ${ }^{37}$. La otra obra inédita a la que hemos aludido es El gran tesoro de la lengua española ó dicionario nuevo explicado en francés, compuesto por Franz Jacob Leys, que lo tenía terminado en 1721 pero cuyos esfuerzos por verlo impreso no se vieron coronados por el éxito, por lo que nos ha llegado en dos conjuntos de manuscritos conservados en Erlangen y Gotha. Hubo más fortuna, por lo contrario, con otro diccionario que, como en el caso del de Torre y Ocón, su autor no llegó a ver impreso en vida; nos referimos al Diccionario castellano con las voces de ciencias y artes y sus correspondientes en las tres lenguas, francesa, latina e italiana, de Esteban de Terreros y Pando.

Terreros, en su tarea de traducir Le spectacle de la nature (1732) de Antoine-Noël Pluche, concibió la idea de componer un diccionario castellano de términos especializados, si bien acabó elaborando un diccionario general, rico en voces de las artes y las ciencias, completado con los equivalentes en latín, italiano y francés. A pesar de que la expulsión en 1767 de los jesuitas, orden a la que pertenecía Terreros, impidió la publicación de la obra, que ya contaba con licencia de impresión desde 1765, el espíritu ilustrado dejó sentir sus efectos: el interés que mostró por ella el estadista Floridablanca hizo posible que Francisco Messeguer y Miguel de Manuel se encargaran de editarla en tres tomos (1786, 1787 y 1788). En 1793, además, este último compone un cuarto tomo donde las equivalencias en otras lenguas ofrecidas en los tres tomos de entradas castellanas vienen recopiladas en forma de tres diccionarios bilingües unidireccionales: uno latín-español, un segundo francés-español y otro más italiano-español. El francés-español, si no en otros aspectos, es comparable e incluso superior en número de entradas a los demás diccionarios bilingües que hemos comentado. Recuérdese, en fin, que, anteriormente a Terreros, Herrero pensó ya en la posibilidad de ofrecer por una vía diferente, es decir, basándose en el enciclopédico Trévoux, un vocabulario francés-español de términos de especialidad, si bien, arredrado ante la empresa o imposibilitado de llevarla a cabo, el suplemento con tales términos que proyectó para su diccionario bilingüe (1743-1744) no llegó nunca, como hemos dicho, a ser una realidad ${ }^{38}$.

\footnotetext{
${ }^{37}$ Sobre esa obra manuscrita, véanse Murgades (1989: 109), Colón \& Perea (2005).

${ }^{38}$ Sobre el diccionario de Terreros, véanse Alvar Ezquerra (1993), Álvarez de Miranda (1992), San Vicente (1995), Azorín Fernández (2000: 201-227), Guzmán Galiano (2000). Especial atención prestan al carácter plurilingüe de la obra Cazorla Vivas (2002a: 245-262), San Vicente (2008).
} 
En lo que se refiere a obras propiamente políglotas con el español y el francés, habría que empezar mencionando la permanencia del ya histórico Calepino, proveniente del inicio del siglo XVI (1502) y, durante el XVIII, reeditado repetidamente en Padua, con siete lenguas, hasta el último cuarto del siglo (1778-1779). Pero, como acabamos de decir, este diccionario es más una pervivencia que una obra característica del XVIII. Las obras políglotas de este siglo seguirán otros derroteros ${ }^{39}$. Uno de estos corresponde a un modelo que puede incluirse también entre las formas heredadas: el de la nomenclatura temática en varias lenguas, de las que es exponente una obra editada todavía en el primer cuarto del siglo y titulada A Vocabulary in six Languages: viz. English, Latin, Italian, French, Spanish, and Portuguese (Londres, 1725), de John Andree ${ }^{40}$. Otros modelos responden ya a las nuevas preocupaciones científicas del siglo y aparecen en las décadas finales de la centuria. Así, los listados de un número relativamente pequeño de palabras pero ofrecidas en una amplia colección de lenguas. Es el proyecto que llevó a cabo Peter Simon Pallas, bajo el patrocinio de la zarina Catalina II, en su Linguarum totius orbis vocabularia comparativa; en su primera edición (San Petersburgo, 1787-1789), reunía doscientas palabras de más de dos centenares de lenguas de Europa y Asia, a las que se añadieron otras ochenta de África y América en la segunda edición (San Petersburgo, 1790-1791). Un proyecto similar lleva a término paralelamente Lorenzo Hervás: en su Vocabolario poliglotto con prolegomeni sopra più di CL lingue (Cesena, 1787) recoge sesenta y siete términos usuales en más de cien idiomas ${ }^{41}$.

No obstante, obras cuales las de Pallas o Hervás poco pudieron servir a los francófonos o hispanohablantes que quisieran acceder al español o al francés con el afán de aprenderlos, de traducir o de solucionar un problema puntual de equivalencias; más que obras lexicográficas propiamente dichas, son estudios sobre las familias de lenguas del mundo. Distinto, pese a su carácter igualmente científico, es el caso del catálogo cuatrilingüe latíncastellano-valenciano-francés de las plantas mencionadas en las Observaciones sobre la historia natural, geografia, agricultura, población y frutos del Reyno de Valencia (Madrid, 1795-1798), incluido por su autor, Antonio José de Cavanilles, en el segundo tomo (Quilis Merín 2002). Y hay que recordar aquí que se reeditó frecuentemente en el transcurso del siglo XVIII -la última reedición parece datar de 1781- el Libro de los secretos de agricultura, casa de campo y pastoril, de Miquel Agustí, proveniente de principios del siglo anterior. Como ya hemos señalado, esta obra contenía un vocabulario -con entradas en castellano y equivalencias en catalán, latín, portugués, italiano y francés- relativo a las plantas y demás materias de las que se trataba en ella ${ }^{42}$. En la misma línea temática se sitúa

\footnotetext{
${ }^{39}$ Sobre la lexicografía plurilingüe del siglo XVIII, véase Alvar Ezquerra (2005).

${ }^{40}$ Sobre Andree, véanse Martín Gamero (1961: 74-75), Ayala Castro (1992: 148), García Aranda (2003: 672-673).

${ }^{41}$ Sobre Hervás, véanse Breva Claramonte (1991), Fuertes Gutiérrez (2005).

${ }^{42}$ También Clavijo y Fajardo, traductor de la Histoire naturelle de Buffon, dice haber estado compilando durante nueve años un vocabulario trilingüe sobre esa materia, finalmente, como en el caso de otros autores, nunca impreso: "Mi primer pensamiento, quando ya tuve formado este Vocabulario de Historia Natural en los idiomas Castellano, Latino y Francés, fue darle á luz [...]. Varias reflexiones me han hecho desistir por ahora de este propósito" (1785, t. I: IV-V; citado por Julia Pinilla, 2008: 93).
} 
también el Allgemeines Polyglotten-Lexicon der Naturgeschichte mit erklaerenden Anmerkungen. Wörterbuch der Naturgeschichte in der deutschen, holländischen, dänischen, schwedischen, englischen, französischen, italienischen, spanischen und portugiesischen Sprache (Hamburgo / Leipzig, 1793-1798), de Philipp Andreas Nemnich, quien publicó además el Waaren-Lexicon in Zwölf Sprachen (Hamburgo / Leipzig, 1797), un conjunto de once diccionarios bilingües en los que la lengua meta es siempre el alemán y la lengua de entrada, por este orden y respectivamente, el inglés, neerlandés, sueco, danés, francés, italiano, español, portugués, ruso, polaco y latín. A estos once vocabularios se añade un duodécimo que forma parte de nuestro corpus: en él, cada entrada del léxico comercial alemán, presentado por orden alfabético, va seguido de las equivalencias en las once lenguas señaladas, lo cual constituye un verdadero léxico especializado políglota. Antes de finalizar el siglo aparecerá una versión de esta obra en que la lengua de entrada ya no será el alemán, sino el inglés (An universal European dictionary of merchandise, in the English, German, Dutch, Danish, Swedish, French, Italian, Spanish, Portuguese, Russian, Polish \& Latin languages, Londres, 1799). Y este mismo idioma, el inglés, había sido ya la lengua de entrada de un diccionario publicado igualmente en Inglaterra unos veinte años antes y compuesto por Daniel Lobo: A nomenclature; or, Dictionary, in English, French, Spanish, and German, of the Principal Articles manufactured in this Kingdom; more particularly those in the hardware and cutlery trades; the goods imported and exported, and nautical terms (Londres / Birmingham, 1776) ${ }^{43}$.

También en el campo de la marina comenzarán a aparecer los primero diccionarios políglotas. Si no llegó a imprimirse el de Tomás Sotuel (Diccionario universal de Marina, 1777; daba las equivalencias francesas e inglesas de las entradas españolas, recogiéndolas al final en un vocabulario español-francés y otro español-inglés), sí vieron la luz el Allgemeines Wörterbuch der Marine (Hamburgo, 1794-1798), de Johann Hinrich Röding, con equivalentes en neerlandés, danés, sueco, inglés, francés, italiano, español y portugués para las entradas alemanas, así como A Marine Pocket-Dictionary, of the Italian, Spanish, Portuguese and German Languages, with an English-French, and French-English Index (Londres, 1799), de Henry Neuman.

Todo esto prefigura ya algo que será frecuente en el siglo XIX: la edición de diccionarios plurilingües de marina, de arte militar, de comercio... es decir, de diccionarios plurilingües de léxico de especialidad.

Particularmente relevante, en este siglo como en otros, es la lexicografía didáctica, es decir, el conjunto de obras que contienen nomenclaturas distribuidas por temas y destinadas al aprendizaje del léxico fundamental. No es lo más usual que estas nomenclaturas se editen como libros íntegramente dedicados a ellas; lo habitual es que sean un complemento a

\footnotetext{
${ }^{43}$ Puede verse también como una obra plurilingüe de vocabulario especializado el Diccionario de los nombres propios de hombres y mugeres, en las quatro lenguas Castellana, Latina, Francesa é Italiana (Madrid, 1793), de Agustín Álvarez Pato. Los listados de topónimos o antropónimos fueron frecuentes en nuestros diccionarios bilingües, que los presentaban como anejos cuando no los incluían en su lugar alfabético correspondiente dentro del cuerpo de las obras. Es igualmente frecuente que las nomenclaturas temáticas bilingües o plurilingües reserven un apartado a los nombres propios de persona.
} 
obras de carácter gramatical, es decir, un complemento a gramáticas del español para francófonos o del francés para hispanohablantes.

Entre las nomenclaturas publicadas como tales destaca la versión del Indiculus universalis que Thomas Croset dio a la imprenta en 1705. La primera edición de esta obra, debida a François Pomey, data de 1667; siempre había consistido en una nomenclatura francolatina, a la que Croset añade ahora las equivalencias castellanas, presentándola así en apartados temáticos cuyos vocablos siguen el orden español-latín-francés, a veces encabezados por introducciones narradas o dialogadas ${ }^{44}$.

Para volver a encontrar la publicación independiente de una nomenclatura perteneciente a nuestro corpus hay que esperar hasta 1771; Josep Broch publica entonces, en Barcelona, su Promptuario trilingüe en catalán, español y francés, expresamente presentado por el autor como destinado al aprendizaje del tercero de estos idiomas a través de los dos primeros. Tiene el valor de ser la única obra didáctica de carácter lexicográfico con el catalán, el español y el francés que se publica en el siglo XVIII; como hemos visto, la anterior que presentaba parcialmente ese carácter fue el Dictionario $(1642,1647)$ de Lacavallería. Volveremos a esta nomenclatura de Broch más adelante ${ }^{45}$.

Pero, como hemos dicho, lo más usual es que las nomenclaturas temáticas con el español y el francés formen parte de conjuntos más amplios. Uno de los primeros ejemplos del siglo lo ofrecen probablemente las varias impresiones sin fecha que se hacen en Bayona del Tresor des trois langues françoise, espagnole et basque. La obra en sí pertenece más bien al siglo anterior que al XVIII; ya había aparecido con tal título y sin nombre de autor en 1642, también en Bayona, aunque se trataba en realidad de la misma obra que Voltoire había publicado en Lyon, hacia 1620, con el título de L'Interprect ou Traduction du François, Espagnol \& Basque ${ }^{46}$. En las impresiones sin fecha de, posiblemente, inicios del XVIII, la estructura de la obra ha cambiado; aunque se conservan los diálogos trilingües español-francés-vasco, ya no está el vocabulario francés-vasco de ediciones anteriores: tanto los cuentecillos que siguen a los diálogos como la nomenclatura que sigue a los cuentos están en versión español-francés, esta última según el modelo de la nomenclatura de C. Oudin, de la que ya hemos hablado ${ }^{47}$.

\footnotetext{
${ }^{44}$ Sobre el Indiculus de Pomey, véanse Quemada (1968: 366-367), Ayala Castro (1996).

${ }^{45}$ No llegaron a la imprenta algunos proyectos políglotas dieciochescos con el catalán. Ya hemos hablado del de Clavijo (véase la nota 42). También se tienen noticias de otros tales como el Dictionarium novem linguis (latín, griego, hebreo, francés, italiano, alemán, español, inglés, catalán), anterior a 1765, fecha de la muerte de su autor, Mateu Alsinet; o como el diccionario de cinco lenguas (latín, español, francés, catalán, griego, italiano) que comenzó Daniel Finestres i de Monsalvo, si bien parece que no sobrepasó la letra A en lo relativo al latín y el español y que solo añadió las equivalencias en francés, catalán y griego en las tres primeras hojas del manuscrito, hoy perdido (Casanovas 1931: 456, citado por Colón \& Soberanas 1986: 137).

${ }^{46}$ Véase nuestra nota 25

${ }^{47}$ Igual que sucedió, como hemos visto, a ciertas composiciones con el catalán, el español y el francés, tampoco llegó a la imprenta ninguno de los proyectos plurilingües del XVIII con el vasco, el español y el francés cuya existencia se conoce o se sospecha. No lo hizo la obra políglota francés-vasco-griego-céltico-árabe-latín-góticoalemán-español-italiano de Jean-Philippe Béla, que recuerda la corriente lexicográfica de interés por la diversidad de lenguas propia de los últimos decenios de la centuria; y tampoco logró imprimirse el posible proyecto
} 
Ahora bien, la nomenclatura derivada de C. Oudin que más influencia tendrá en el siglo XVIII, e incluso más allá, es la que Francisco Sobrino había incorporado a sus Diálogos nuevos en español y francés (1708). No era la primera que Sobrino publicaba: como hemos explicado, en la edición príncipe (1705) de su Dicionario nuevo ya se podía hallar una, de la que se prescindió desde la segunda edición de 1721, muy probablemente porque, dentro del completo conjunto didáctico para la enseñanza del español que, como su modelo Oudin, Sobrino preparó y editó, debió de parecerle que el lugar apropiado para una nomenclatura eran más bien los Diálogos que el Diccionario; por lo demás, eso permitiría abaratar costes en la publicación y/o en la venta de este último, ya de por sí bastante caro a juzgar, no solo por lo que fácilmente cabe deducir de su volumen, sino por los varios testimonios que a todo lo largo del siglo aluden a ello. La nomenclatura de los Diálogos nuevos de Sobrino coincide hasta en el título ("Nomenclator de algunas cosas curiosas y necessarias de saver") con la de los Dialogos muy apazibles de César Oudin, su principal fuente en esta como en sus demás obras; si la "Méthode facile pour apprendre la langue espagnole; Par l'arangement des mots selon la construction de l'univers, avec les principaux termes des Arts et des Sciencies", es decir, la nomenclatura incluida en el Dicionario de Sobrino, se basaba en el Indiculus de Pomey, el "Nomenclator" de sus Diálogos es básicamente el de C. Oudin (posiblemente según su última edición de 1675) con algunas partes sacadas de Pomey. Las reediciones de los Diálogos de Sobrino se sucederán a todo lo largo de la centuria hasta 1787 , por lo que su nomenclátor será una fuente continua de inspiración para otros autores ${ }^{48}$.

Contemporáneas de la primera edición (1708) del "Nomenclator" de Sobrino son otras dos nomenclaturas. Una, la "Nomenclature Françoise et Espagnolle, reduite dans un ordre facile", es ligeramente anterior: apareció en la Nouvelle grammaire de la langue espagnolle (París, 1704) de Jean Perger. La otra es unos años posterior: la incluye Matthias Kramer al final de su Grammatica \& syntaxis linguae hispanicae (Núremberg, 1711). La de Perger trae las entradas en francés y las equivalencias en español, mientras que la de Kramer las da en español con los equivalentes en francés, e incluso a veces en latín y raramente en italiano. Ambas nomenclaturas son independientes tanto del modelo de Oudin como del de Pomey y, quizá porque no fueron reeditadas, no tendrán sobre autores posteriores una influencia comparable a la ejercida por el nomenclátor de Sobrino, si bien es cierto que la de Perger, favorecida sin duda por su lugar de edición, acabará por servir de inspiración, como diremos, a alguno de ellos ${ }^{49}$.

cuatrilingüe vasco-latín-francés-español de Juan Etxeberri de Sara (atribución dudosa), compuesto en torno a 1710 y hoy perdido.

48 Sobre la nomenclatura de la edición de 1705 del Tesoro, véase García Aranda (2003: 664-665). Sobre la nomenclatura de los Diálogos, Ayala Castro (1992: 144-145), Cazorla Vivas (2002: 52-97), García Aranda (2003: 665-667), Bruña Cuevas (2008c: 194-195).

${ }^{49}$ Sobre la obra de Perger, véase Sáez Rivera (2007: 477-497). Sobre la de Kramer, Christ (1991), Ayala Castro (1992: 145-146), Bray (2000), Sáez Rivera (2007: 977-1033). 
En la segunda parte del XVIII, estos vocabularios temáticos bilingües aparecen frecuentemente, además de en las obras destinadas primordialmente al aprendizaje del español, cuales son las que acabamos de ver, en obras destinadas al aprendizaje del francés por hispanohablantes ${ }^{50}$. La sombra del "Nomenclator" de Sobrino -siempre presente, como hemos dicho, por las reediciones de los Diálogos- se acrecienta ahora al servir de inspiración a la nomenclatura incluida en la que será durante varios decenios la gramática francesa para españoles más conocida o, en todo caso, tras la aparición del Chantreau, una de las más conocidas hasta su última edición en 1800; nos referimos a la Llave nueva, y universal, para aprender con brevedad, y perfeccion la Lengua Francesa (Madrid, 1748), de Antoine Galmace ${ }^{51}$. También ahora, como ocurrió entre las nomenclaturas de Sobrino y Oudin, el propio título muestra su filiación: el que Galmace dio a la suya fue "Recopilacion de muchas, y diferentes voces muy curiosas, y necessarias de saber" ${ }^{32}$.

Otra gramática francesa ofrece una nomenclatura fuertemente influenciada por la de Sobrino: el Arte Francés (Barcelona, 1750). Este Arte es muchísimo menos conocido que la Llave de Galmace, tanto por el menor prestigio de su autor, el francés Sebastián Roca y María, como por razones editoriales (nunca fue reeditado), lo que no impedirá que su nomenclatura ejerza cierta influencia sobre algún autor posterior. Esta lleva por título "Repertorio de el Arte Francés. Cap. XVII. Que contiene algunos terminos proprios domesticos" (1750: 345-395). Es probable que Roca ya la tuviera preparada o bastante avanzada cuando Galmace se le adelanta ligeramente en la edición de la suya (1748); lo cierto es que, aunque llegara a conocer la de este último antes de terminarla, la nomenclatura de Roca está basada primordialmente, no en la de Galmace, sino en la de Perger (1704), si bien completada, hasta alcanzar 2040 entradas, con la fuente directa de Galmace, es decir, con el nomenclátor de los Diálogos de Sobrino ${ }^{53}$.

Ya hemos tratado del Promptuario (1771) de Broch. Aparecido en Barcelona como el Arte de Roca, no puede extrañar que, pese a la poca repercusión que parece haber tenido

\footnotetext{
${ }^{50}$ Esto no quiere decir que ninguna de las gramáticas de francés para españoles publicadas en la primera mitad del siglo contuviera una nomenclatura. Abdón Senén Guilla Rubí terminaba con una "Nómina española y francesa" (entradas en español) su Forma gramatical, la qual contiene el modo como se ha de aprender à leer, y hablar la lengua Francesa (Madrid, 1707); tiene la particularidad de incluir un último epígrafe poco frecuente en nuestras nomenclaturas: el dedicado a los "Nombres injuriosos". También Francisco de la Torre y Ocón, en su Nuevo Methodo breve, vtil, y necessario para aprender a escribir, entender, y pronunciar las dos principales Lenguas, Española, y Francesa (Madrid, 1728), incluye algunos listados temáticos, pero no llegan a constituir una verdadera nomenclatura. Sobre la enseñanza del léxico del francés a los hispanohablantes en las gramáticas del siglo XVIII, véase Lépinette (2000: 254-269).

${ }^{51}$ Galmace declara en sus Adiciones a la Gramatica Francesa, que compuso el R. P. Nuñez (Madrid, 1745) estar elaborando un diccionario bilingüe francés-español: “[...] facilitaràs la traduccion de los Libros Franceses, con el auxilio del Diccionario de Sobrino, ù otro semejante; (interin te ofrezco el mio, que actualmente estoy trabajando, con deseo que en èl no falten tantas voces como se echan menos en los que hasta oy se conocen en España)..." (1745: 40-41). Pero, caso de que realmente lo estuviera componiendo, el hecho es que nunca lo dio a la imprenta.

${ }^{52}$ Recuérdense los títulos empleados por Sobrino y Oudin. El primero tituló su nomenclatura "Nomenclator de algunas cosas curiosas y necessarias de saver"; y el segundo, "Nomenclátor o registro de algunas cosas curiosas y necesarias de saberse en los estudios de la lengua española”. Sobre la nomenclatura de Galmace, véanse Lépinette (2000: 258-260), Bruña Cuevas (2008c: 190-194).

${ }^{53}$ Sobre la nomenclatura de Roca y María, véase Bruña Cuevas (2008c: 195-197).
} 
esta última obra fuera de su zona geográfica de edición, Broch la conociera. El "Repertorio" de Roca es así una de sus fuentes fundamentales; la otra es el "Nomenclator" de Sobrino, tanto en sí mismo como a través de su reelaboración por Galmace; y una tercera fuente puntual será el vocabulario en seis lenguas del Libro de los secretos de agricultura de Miquel Agustí. Broch sabrá reestructurar y enriquecer sus diversas fuentes, además de buscarles equivalentes en catalán, para ofrecer a quienes tenían esta lengua como materna una obrita cómoda y barata con la que acceder al vocabulario básico del francés y del castellano 54 .

Una de las nomenclaturas más curiosas, por su modo de insertarse en la obra marco, es la que se encuentra en la Gramatica Española y Francesa (Madrid, 1763) de Pierre Contaut. El autor lleva a su extremo una de las prácticas de algunos vocabularios temáticos: la de acompañar las entradas y las equivalencias del artículo para indicar el género. Así lo hace Contaut, pero no se limita al artículo singular, sino que da también el plural de la entrada acompañado de su artículo plural. Las entradas adoptan así formas del tipo la canoa, las canoas, o bien el navio velero, los navios veleros, para las que se dan las correspondientes traducciones al francés en singular y plural, con indicación de que el género en francés cambia cuando tal es el caso y el artículo no lo indica en esta lengua. El resultado es la mayor parte de las veces una nomenclatura poco económica, dado que el autor no busca expresamente términos que pudieran tener un plural particular y desaprovecha incluso ciertas ocasiones en que su método hubiera podido ser útil, como cuando, quizá por desconocimiento o por error, da la entrada la ancora, las ancoras. Esta presentación deriva de que la nomenclatura incorporada a esta gramática no está concebida, sin más, como un anejo destinado a la adquisición del léxico, sino como una ilustración práctica de uno de los capítulos de contenido gramatical: el capítulo XVI, en que se explican los artículos y los adjetivos demostrativos y posesivos franceses, lleva por título "De los Articulos, y Pronombres mas usados, que distinguen los generos Masculino, y Femenino en la Lengua Francesa", titulándose el capítulo siguiente, el XVII, en que empieza la nomenclatura, "Tabla de cinco classes de Nombres Substantivos, escritos en el singular, y plural, según la forma de los cinco Articulos, y Pronombres mencionados. La primera classe es de los nombres del Cielo, y de la Iglesia". Los cuatro capítulos siguientes siguen presentando otros apartados temáticos de la nomenclatura. Esta se interrumpe de nuevo en los capítulos XXII a XXIV para nuevas explicaciones gramaticales, reanudándose en los capítulos XXV a XXIX como supuesta ilustración de lo explicado.

Pero la nomenclatura más innovadora de la segunda mitad del siglo es la de PierreNicolas Chantreau. En su Arte de hablar bien Frances (Madrid, 1781) incluye un "Suplemento" con paginación propia a cuya cabeza se halla una nomenclatura temática español-francés dividida en tres capítulos. Esta tripartición es nueva en nuestro corpus. El primer capítulo contiene solo adjetivos calificativos, justificando el autor que abran la nomenclatura por el hecho de que "con un solo adjetivo se pueden calificar muchos sustantivos, y que por consiguiente importa mas saber aquellos antes que estos" (1797: 1). Como se ve, su razonamiento responde a las motivaciones pedagógicas que, en general, son la justificación última de las nomenclaturas temáticas. Contrariamente a los otros dos

\footnotetext{
${ }^{54}$ Sobre la obra de Broch, véanse Colón \& Soberanas (1986:120-121), Bruña Cuevas (2008c).
} 
capítulos, el de los adjetivos no se reparte en subgrupos, si bien se observa que el autor coloca primero los que expresan cualidad física, luego los de cualidad moral y finalmente los del color. El segundo capítulo, dedicado a los verbos, nos parece el más innovador, tanto por su propia presencia en un repertorio temático como por la inclusión de epígrafes tales como "Del estudiar", "Del hablar", "Acciones de amor y odio", "Acciones militares",55, etc. El último capítulo, sobre sustantivos, es el que más se parece a las nomenclaturas anteriores, aunque no está exento igualmente de cierta originalidad ${ }^{56}$.

El Arte de Chantreau será reeditado dos veces más en el siglo XVIII. Alcanzará tal fama que, desde principios del XIX, las reediciones en diversas ciudades de España y Francia harán que la palabra Chantreau se convierta prácticamente en un sinónimo de "gramática francesa para españoles". La nomenclatura correspondiente servirá así de base para el aprendizaje del léxico francés por miles de españoles. Muchos serán los autores que revisarán el Chantreau o que se inspirarán de él para componer sus propias gramáticas; entre ellos, posiblemente el primero fuera Félix Martínez Saavedra en lo que a la nomenclatura se refiere. Este autor compuso un Compendio de la Gramatica Francesa (Sevilla, 1791) inspirado del Abrégé des principes de la grammaire françoise (París, 1739), de Pierre Restaut; la nomenclatura que en tal Compendio se incluye está basada, no obstante, en Chantreau, si bien Martínez Saavedra la varía notablemente (desaparición en cuanto tal del capítulo de verbos, colocación del listado de adjetivos tras el de los sustantivos...).

Aunque las nomenclaturas distribuidas en apartados temáticos son la opción preferida por las gramáticas para la enseñanza del francés o del español que incluyen listados léxicos, algunas optaron por los listados alfabéticos, ofreciendo así una suerte de diccionarios elementales incorporados a la propia obra que servía de base para aprender el idioma extranjero. En una época en que los diccionarios de bolsillo aún no existían, estos vocabularios alfabéticos cumplieron una función similar: evitaban el desembolso que suponía la adquisición de un diccionario bilingüe, suponían una comodidad y estaban adaptados al nivel básico de conocimientos de quienes eran sus destinatarios. De hecho, y dado el espacio que ocupaban en las obras, también podrían considerarse como diccionarios de bolsillo acompañados de una gramática. En nuestro corpus del siglo XVIII descuellan dos, ambos aparecidos en obras orientadas primordialmente al aprendizaje del español por francófonos.

El primero se halla en la Grammaire et Dictionnaire François et Espagnol (París, 1701), de Guillaume de Maunory; la parte gramatical, centrada en el castellano, ocupa las páginas 1-80 y el resto de la obra (páginas 81-237) se dedica al "Dictionnaire François et Espagnol", unidireccional con las entradas en francés, como indica su título ${ }^{57}$. La obra,

\footnotetext{
${ }^{55}$ No se olvide que Chantreau era maestro en la Real Escuela Militar de Ávila.

${ }^{56}$ Sobre la obra de Chantreau puede consultarse la tesis de Moreu Huet (1990). Sobre su nomenclatura, Ayala Castro (1992: 149-151), Lépinette (2000: 261-269), García Aranda (2003: 674-676).

${ }^{57}$ Sobre ese diccionario, véanse Cazorla Vivas (2002: 41-49), Sáez Rivera (2007: 471-473).
} 
gracias a su parte lexicográfica, pudo tener su atractivo frente a otra gramática de español que ya estaba en el mercado desde 1697, aunque lanzada desde Bruselas: la Nouvelle grammaire espagnole de Francisco Sobrino. Quizá por ello, vuelve a salir en 1704 y 1708; y aunque es cierto que no se reeditó posteriormente, pudo ser la causa de una innovación importante introducida en la gramática de Sobrino desde su edición de 1717: la incorporación de un Pequeño Diccionario Español y Francés y de un Petit Dictionaire François \& Espagnol, según reza el título de portada. Adaptándose al carácter bilingüe de la obra, en este caso se trata de un vocabulario alfabético bidireccional, más elemental que el Diccionario nuevo del mismo autor y complemento adecuado para quienes, por haber adquirido también otra de las obras de Sobrino, los Dialogos nuevos, tuvieran acceso al nomenclátor temático que en ella se ofrecía. La reedición continua de las obras de Sobrino a lo largo del siglo mantienen así siempre presentes las dos propuestas lexicográficas de acceso al vocabulario esencial: la del vocabulario alfabético (bidireccional) y la de la nomenclatura temática (monodireccional español-francés). Esta, por lo demás, acabará incorporándose a la gramática de Sobrino en sus reediciones tardías, reuniéndose así en una misma obra los dos tipos de listados léxicos (véase, por ejemplo, la edición de 1798 impresa en Aviñón).

Así pues, al terminar el XVIII la incorporación tanto de nomenclaturas temáticas como de vocabularios alfabéticos a las obras para el aprendizaje de lenguas extranjeras era un recurso didáctico bien conocido. La gramática de Sobrino y la de Chantreau lo llevarán hasta el siglo XIX, como tendremos ocasión de comentar.

\section{SIGLO XIX}

En la perspectiva histórica de este estudio, es rasgo llamativo del siglo XIX la multiplicación de las obras lexicográficas de todo tipo, y muy especialmente las compuestas para la enseñanza secundaria, la cual adquiere cada vez más presencia en la sociedad; a ella se destina un alto número de diccionarios de bolsillo y de nomenclaturas incluidas en los manuales escolares. Unos y otras habían existido ya en época anterior, como hemos visto; es su gran proliferación lo verdaderamente llamativo en el XIX. Naturalmente, también se editarán diccionarios de gran formato destinados a traductores y a personas con un dominio avanzado del español o el francés como lenguas extranjeras. A menudo, incluso, el diccionario en gran formato de un mismo autor o una misma editorial saldrá también al mercado en edición de bolsillo, según una práctica que sigue vigente hoy día y que ya se había inaugurado con el diccionario de Gattel desde los años finales del siglo XVIII.

Los dos diccionarios de Gattel -el de gran formato y el de bolsillo- así como el diccionario de Cormon dominaban el panorama lexicográfico francoespañol al abrirse el siglo, como ya hemos expuesto. Pero, rápidamente, ambos autores se verán relegados por el prestigio de un nuevo nombre: el de Antonio de Capmany. Seguramente para evitar las importaciones desde Lyon, el impresor Sancha, de Madrid, encargó a Capmany, antes de terminar el siglo XVIII, una remodelación de la obra de Gattel. Tras varios años de trabajo, lo que Capmany entregó al impresor fue en realidad un nuevo diccionario bilingüe, muy enriquecido en equivalencias españolas con respecto al modelo de partida. Este Nuevo diccionario francés-español (Madrid, 1805) iba precedido, además, de un largo prólogo 
donde Capmany atacaba duramente a sus competidores más directos -Gattel y Cormon-, descalificando toda obra lexicográfica que, teniendo como lengua meta el español, estuviera compuesta por un autor extranjero. Naturalmente, la contrapartida de tal posición es que Capmany no pudiera componer una segunda parte español-francés para su obra ${ }^{58}$.

Ese carácter unidireccional del diccionario de Capmany fue también su principal debilidad. Plagiado en París por Melchor Manuel Núñez de Taboada en su Diccionario español-francés y francés-español, más correcto y completo que todos los que se han publicado hasta ahora, sin exceptuar el de Capmany (1812), esta nueva obra, que tenía la ventaja de ser bidireccional (con la parte español-francés basada en Gattel) y de estar lanzada desde un centro editorial potente, acabará por dominar el panorama lexicográfico de la primera mitad del siglo, ampliando incluso su presencia, por sí mismo y a través de otros diccionarios a los que sirve de fuente, hasta el último cuarto de la centuria ${ }^{59}$. Pocos nombres, entre los de los lexicógrafos de nuestro corpus, alcanzaron mayor resonancia que el de Núñez de Taboada. Ciertamente, Sancha, desde Madrid, volverá a editar el Capmany en 1817, pero ya en 1820 lo que imprime es el Taboada. Desde Francia o desde España, este último conocerá frecuentes reediciones, legales o fraudulentas, presentando a Núñez de Taboada como autor de la obra u ocultando su autoría, en versión original o en versión más reducida de bolsillo. Los propietarios en Francia de los derechos legales sobre el diccionario incluso emprendieron acciones legales para evitar los plagios, pero, aunque ganaron su causa, no llegaron a impedir realmente el uso del nombre de Taboada en muchas ediciones realizadas en Francia, y mucho menos en las de España. La aparición en Madrid del Nuevo diccionario portátil español-frances ó Compendio del diccionario grande de Nuñez de Taboada, mucho mas aumentado que la edicion impresa en Paris en 1823 (Madrid, 1825), de Francisco Grimaud de Velaunde, es uno de los primeros ejemplos de ello, junto con la edición de Sancha (1820) a la que ya nos hemos referido. Y, además, a estas y otras ediciones de Madrid vendrán a sumarse, desde los años cuarenta, las de diccionarios francoespañoles impresos en Barcelona que se presentaban como taboadas revisados y ampliados. La imprenta de Antonio Bergnes comenzará la serie barcelonesa, pronto relevada, hasta los años ochenta, por la de Oliveres y la de Pujal. Son ediciones que rivalizan entre ellas por presentarse como más ricas que las anteriores, como superiores no ya solo al Capmany -nombre que, inesperadamente, se hace así sobrevivir en el recuerdo-, sino igualmente a los diccionarios de otros autores salidos a lo largo del siglo y que realmente pudieron servir de modelo inmediato, por más que a su vez pudieran derivar más o menos directamente del Taboada (nos referimos a diccionarios como el de Martínez López, por ejemplo). Es lo que se refleja en títulos como los siguientes:

Nuevo diccionario francés-español y español-francés, más completo que cuantos se han publicado hasta el día, redactado sobre el de Núñez de Taboada, y aumentado con más de 10.000 voces y 10.000 acepciones nuevas que no se hallan en el de dicho autor (Barcelona, A. Bergnes y Compañía, 1840-1841).

\footnotetext{
${ }^{58}$ Sobre Capmany y el conjunto su obra lingüística, véanse Fernández Díaz (1985) y Étienvre (2001). Sobre su diccionario, Roig (1995), Bruña Cuevas (1999a: 54-56; 1999b), García Bascuñana (1999), Cazorla Vivas (2002: 355-378).

${ }^{59}$ Sobre el diccionario de Taboada, véanse Bruña Cuevas (1999a: 56-57), García Bascuñana (1999), Cazorla Vivas (2002: 379-422, 499-520).
} 
Novísimo diccionario francés-español y español-francés. El más completo de cuantos se han publicado en España y en el extranjero hasta hoy día. Redactado sobre el de Núñez de Taboada y aumentado con más de 12.000 voces y 12.000 acepciones nuevas que no se hallan en los de Capmany, Salvá, Martínez López y demás autores modernos, así nacionales como extranjeros (Barcelona, J. Oliveres, 1859).

Verdadero Taboada. Completísimo diccionario español-francés y francés-español, más exacto y correcto que todos los que se han publicado hasta el presente sin exceptuar el de Capmany (Barcelona, E. Pujal, 1880).

Entre los diccionarios de la primera mitad del XIX que se editan con nombre de autor, cabe citar los de bolsillo debidos a G. Hamonière (1820), Louis-Adrien Berbrugger (1829), Domingo Gian Trapani (1838), Eugène Orrit (1843) o J. F. Quintana (1843-1845), todos aparecidos en Francia, casi siempre en París. De mayor envergadura, y sobradamente basados en los diccionarios de Capmany y Taboada, son el de D. G. Trapani y A. de Rosily (1826) -anterior, pues, al de formato bolsillo que lleva por autor a Trapani-, el de Pedro Martínez López y Fr. Maurel (1839-1840) o el de José da Fonseca (1840), lanzados igualmente desde París. Este último, buscando quizá distinguirse de los demás ofreciendo algo novedoso, incluye en la microestructura y en suplemento un nutrido número de frases sacadas de autores clásicos y traducidas; vuelve, además, a una práctica en realidad antigua: bajo pretexto de proporcionar la etimología de los lemas, lo que Fonseca ofrece en realidad es la traducción latina de las entradas españolas o francesas de cada parte de la obra: la "etimología" que ofrece para la entrada de origen germánico hanche, por ejemplo, no es sino su equivalente latino coxa. Desde el diccionario de François Cormon (1769; última edición en 1791) no se había vuelto a aportar este apoyo latino para la correcta comprensión de las entradas, ya que, si bien es cierto que también Claude-Marie Gattel (1790; última edición en 1803) lo proponía, solo lo hacía en la parte español-francés, siguiendo así el modelo de su fuente, el diccionario de Pierre de Séjournant (1759; última edición en 1790-1791) $)^{60}$.

Nótese que, primero con el diccionario de Trapani y Rosily y luego con el de Martínez López y Maurel, empieza a aplicarse en la práctica la idea que Capmany defendía en el prólogo de su diccionario monodireccional: la de que, en un diccionario bilingüe, el lexicógrafo encargado de hallar las equivalencias de los lemas debía tener la lengua meta como lengua primera. Capmany no llegó a ponerse de acuerdo con un francófono para que se encargara de la segunda parte de su diccionario, la parte español-francés, que nunca vio la luz por ende. Pero su punto de vista empezó a surtir efecto relativamente pronto (el diccionario de Trapani y Rosily, cada uno encargado de una parte, es de 1826) y continuará dando lugar, hasta nuestros días, a buen número de obras lexicográficas con doble autor, frecuentemente conforme al mismo principio en el reparto de tareas, o a obras que expresamente se declaran como compuestas por un colectivo, dejándose suponer, cuando

\footnotetext{
${ }^{60}$ Recuérdese que el diccionario de Hornkens (1599) es el último de nuestro corpus, antes del de Séjournant, en haber proporcionado correspondencias latinas, si bien su diccionario solo podía ofrecerlas, dado su carácter unidireccional, como complemento a las equivalencias españolas de las entradas francesas. La "innovación" de Fonseca volverá a aparecer en nuestro corpus con el diccionario de Fernández Cuesta, también como etimología del lema, solo que en este caso se trata de un verdadero apartado etimológico, a menudo completado con el resultado de la misma raíz en otras lenguas.
} 
no se consigna expresamente, que habría entre sus miembros -y probablemente los hubiera- hablantes nativos francófonos e hispanohablantes. Entre las del siglo XIX, cabe citar las de Guim y Noriega, Domínguez, Blanc Saint-Hilaire y Jover, Fernández Cuesta o Darbas e Igón.

También tiene doble autor uno de los diccionarios aparecidos antes de mediados de siglo (Toulouse, 1846): el de Francisco Piferrer y Miguel de Neira. No se trata de uno de los grandes diccionarios del XIX, sino de uno de segundo orden, de bolsillo, nunca reeditado y, en realidad, sucesor de un Vocabulaire de poche espagnol-français et françaisespagnol, publicado por Piferrer, también en Toulouse, unos años antes (1841). Eso sí, quizá por esa misma filiación, el Nuevo diccionario de 1846 presenta, como el Vocabulario de 1841, una particularidad llamada a hacer fortuna y defendida expresamente en la advertencia preliminar como uno de los principales atributos de todo diccionario que se preciara: la introducción de la pronunciación figurada correspondiente a los lemas.

Como ya hemos indicado, no es la primera vez que la pronunciación figurada aparece en nuestro corpus. Ya Barthélemy Cormon la había introducido en su diccionario (1800), imitándolo luego Claude-Marie Gattel en la segunda edición de su bilingüe (1803). Pero Capmany (1805) prescindió de tal ayuda y la consideró superflua, por lo que, al convertirse en el modelo de Núñez de Taboada y al ser este la base de la lexicografía francoespañola de la primera mitad del XIX, la pronunciación figurada cayó en desuso durante cuarenta años. Como hemos visto, Piferrer y Neira la reivindican y ya hemos dicho que quizá sea por influencia de una obra propia anterior. Pero no se puede descartar que, además, se vieran confortados en sus convicciones por la publicación, el año anterior (1845), del primer tomo de una obra puntera en nuestra historia: el Diccionario universal francés-español y españolfrancés.

Compuesto, como reza la portada, "por una sociedad de profesores de ambas lenguas, bajo la dirección de D. Ramón Joaquín Domínguez", el Diccionario universal (Madrid, 1845-1846) se publica en seis tomos, lo cual, como su propio título, da ya de por sí una idea de sus altas miras: recoger todo el vocabulario de los respectivos diccionarios de las dos academias de la lengua, la española y la francesa, más el perteneciente a todas las artes y las ciencias. El modelo seguido para ello fue el de partir, para establecer la macroestructura de la parte francés-español, del Dictionnaire national ou Dictionnaire universel de la langue française (París, 1845-1846), de Louis-Nicolas Bescherelle, cuyas entradas pasan, si no todas, sí en gran número a la obra bilingüe. Para la parte español-francés, los lemas son básicamente, aunque en menor cantidad, los del Diccionario nacional o Gran diccionario clásico de la lengua española (Madrid, 1846-1847), preparado paralelamente al bilingüe por el mismo establecimiento léxico-tipográfico, el de Domínguez ${ }^{61}$, y en gran medida inspirado igualmente por el Dictionnaire de Bescherelle. La influencia de tales fuentes, que son las principales pero no las únicas, también se deja ver en la microestructura: lejos de limitarse a proporcionar las correspondencias de cada lema en la otra lengua, el bilingüe de Domínguez las suele acompañar de una definición en la lengua meta, una definición que alcanza con frecuencia un desarrollo considerable, más propio de los diccionarios sobre el

\footnotetext{
${ }^{61}$ La empresa que aparece como responsable de la edición de los tomos II a VI del Diccionario universal se nombra precisamente así: "Establecimiento léxico-tipográfico de R. J. Domínguez".
} 
mundo que de los diccionarios de lengua y, desde luego, inusitado hasta ese momento en la historia de la lexicografía bilingüe con el francés y el español, por más que no fuera nuevo en ese pasado lexicográfico francoespañol que una breve definición se añadiera a los equivalentes de las entradas. En ocasiones, además, esas definiciones del Domínguez pueden reflejar sin pudor el sentir o el punto de vista ideológico del autor del artículo. Estamos, pues, ante un diccionario de carácter abiertamente enciclopédico (de ahí el adjetivo universal que lo califica en su título) y con una fuerte impronta de subjetivismo; para uno y otro rasgo, es el ejemplo más claro de nuestro corpus. A ello se añade, como hemos indicado, la incorporación decidida de la pronunciación figurada de los lemas en las dos partes de la obra, la parte francés-español y la parte español-francés (Bruña Cuevas 2002: 77-78; 2005b: 105-108). La influencia de este diccionario en los nuevos bilingües inmediatamente posteriores y la frecuente incorporación de la pronunciación figurada en los monolingües franceses favorecerán el que ese complemento de información se brinde, más o menos desarrollado según los casos, en casi todos los diccionarios bilingües de nuestro corpus comprendidos entre el Diccionario universal y la época actual. Bien es verdad que, muerto Domínguez a consecuencia de su participación en una de las revueltas políticas decimonónicas, en la segunda y última edición de la obra (Madrid / París, 18531854) se suprime la pronunciación figurada de los lemas españoles, dejándola solo para los franceses, un modelo que hará fortuna convirtiéndose en mayoritario ${ }^{62}$.

Con el Domínguez se rompe la tendencia, nacida hacia principios del XIX, a ofrecer tan solo o bien diccionarios bilingües de bolsillo realmente elementales, o bien diccionarios no demasiado voluminosos. Otros autores, otras editoriales siguen sus pasos y comienzan a proponer, bajo la influencia directa del Domínguez, gruesos diccionarios bilingües, tendentes igualmente al enciclopedismo en cuanto a la cantidad y especialización de los lemas admitidos, si bien despojados de los grandes desarrollos definicionales y del excesivo grado de subjetivismo que caracterizan a su modelo. Es el caso del Nuevo diccionario (París, 1856), atribuido a Vicente Salvá ${ }^{63}$, o del Novísimo diccionario de Saint-Hilaire Blanc (París, 1859), este último más fiel al diccionario de Domínguez que el primero, si bien, de los dos, es el de Salvá el destinado, por número de ediciones y por fama, a mantener una presencia constante en toda la segunda mitad del siglo XIX y a prolongarse a lo largo del XX, periódicamente revisado por diversos lexicógrafos. De hecho, en la década de los setenta del siglo decimonono, y una vez que cesa de publicarse el diccionario de Saint-Hilaire, solo mantiene sus reediciones el de Salvá, del que la editorial parisina Garnier, propietaria de los derechos, saca la séptima edición en $1880^{64}$. Con todo, en 1882 otra de las casas de edición parisinas lanza su propia oferta en nuestro campo con el diccionario de Francisco Corona Bustamante, el cual, aunque menos rico en términos de

\footnotetext{
${ }^{62}$ Sobre Domínguez, véase Seco (1985). Sobre su diccionario bilingüe, Bruña Cuevas (2003b, 2004), Cazorla Vivas (2002a: 545-580; 2003), Quilis Merín (2007).

${ }^{63}$ Los verdaderos autores del diccionario fueron probablemente los que la portada presenta como redactores, es decir, Juan Bautista Guim, para la parte francés-español, y Francisco de Paula Noriega para la parte españolfrancés. Véase Bruña Cuevas (2006b).

${ }^{64}$ Sobre Salvá, véase Lliteras (1989: 7-64). Sobre su diccionario bilingüe, véanse Cazorla Vivas (2002: 643-680), Bruña Cuevas (2004: 39; 2006b).
} 
artes y ciencias que el Salvá, puede incluirse igualmente entre las obras lexicográficas de gran formato de nuestro corpus bilingüe. Poco después, sin embargo, lo supera en riqueza de lemas y en desarrollo de la microestructura otro bilingüe enciclopédico, esta vez editado en España y propuesto en cuatro volúmenes: el Diccionario de las lenguas española y francesa comparadas (Barcelona, 1885-1887), de Nemesio Fernández Cuesta, redactado con la colaboración de Guillermo Graells y Henri Brunswick ${ }^{65}$. Esta última obra, además, gozó de una clara ventaja sobre la de Corona Bustamante: desde 1887, con la publicación del último volumen (letras H-Z de la parte español-francés) la obra es bidereccional al completo, mientras que habrá que esperar a 1901 para que Corona Bustamante saque el segundo tomo de su obra con la parte español-francés; durante casi veinte años, por lo tanto, el diccionario de Corona Bustamante no estuvo disponible más que en la dirección francés-español, según una práctica que nos retrotrae en cierto modo hasta Capmany, autor considerado por Corona Bustamante como base de toda la lexicología del XIX y cuya defensa de la mayor riqueza léxica del español con respecto al francés vuelve a reivindicar. Pero, el diccionario de Corona Bustamante está lejos del Capmany. Tanto el suyo como el de Fernández Cuesta se inspiran, además de en los bilingües, en los grandes diccionarios monolingües franceses y españoles de su siglo. En cuanto a sus fuentes francesas, reflejan, como los diccionarios de Domínguez o de Salvá / Guim / Noriega, la influencia del Dictionnaire national de Bescherelle, pero también la del Dictionnaire de la langue française (París, 1863-1873), de Émile Littré. Como es el caso de este último autor con respecto a Bescherelle, Fernández Cuesta y, sobre todo, Corona Bustamante también presentan menos términos de especialidad que el Domínguez o el Salvá; en cambio, ambos incorporan al final de cada artículo, como también lo hacía Littré, un apartado sobre la etimología del lema ${ }^{66}$, lo cual responde al nuevo ambiente lingüístico propiciado por el desarrollo de los estudios de carácter histórico y comparativo (nótese el calificativo de comparadas que figura en el título del Fernández Cuesta).

Como ya hemos expuesto, estos diccionarios en gran formato no podían ser los más demandados en la segunda mitad del siglo XIX. De ahí que, de todos ellos, únicamente el de Salvá / Guim / Noriega conozca un número significativo de reediciones ${ }^{67}$. Más posibilidades de mercado existían para los diccionarios bilingües de pequeño formato y de

\footnotetext{
${ }^{65}$ Sobre Fernández Cuesta y su diccionario bilingüe, véanse García Bascuñana (1992-1993; 1996: 98-100; 2005), Cazorla Vivas (2002a: 701-726), Bruña Cuevas (2004).

${ }^{66}$ Nada que ver con la equivalencia latina que proporcionaba el diccionario de Fonseca. Por más que este también la presente como la etimología del lema, muy a menudo se trataba simplemente de la traducción. Fonseca, como hemos visto, proponía el vocablo latino coxa para el lema francés hanche, por lo que no hacía sino traducirlo; por el contrario, tanto Corona Bustamante como Fernández Cuesta señalan su origen germánico. Este último, siempre con una microestructura más desarrollada que la de Corona Bustamante, no se limita, además, a señalar simplemente el étimon, sino que, como Littré, reseña sus resultados en diversas lenguas, lo cual, muy a menudo, confiere a estas explicaciones etimológicas un marcado carácter plurilingüe, sin que con ello queramos decir, por razones obvias, que ello acerca este diccionario a los habitualmente considerados políglotas.

${ }^{67}$ Ya hemos hablado de las del Domínguez y las del Saint-Hilaire y hemos señalado que el Corona Bustamante ni siquiera se completó antes de que acabara el siglo; en cuanto al Fernández Cuesta, su única edición en el XIX es la que hemos señalado.
} 
menores pretensiones, válidos para principiantes o para quienes buscaban una correspondencia rápida, o incluso aproximada, a una dificultad puntual. Si ya era así en la primera mitad del siglo XIX, tanto más lo será en la segunda, durante la cual aumenta considerablemente el número de alumnos de enseñanza secundaria y es regular en esta la presencia del francés. De ahí que algunos de los grandes diccionarios se presentaran también en formato de bolsillo y con el mismo nombre de autor; es el caso de los diccionarios en versión abreviada de Saint-Hilaire (¿1840?; tercera edición, Lyon / París, 1847), de Domínguez (Madrid, 1846) y, sobre todo, de Salvá, el más reeditado de todos también en su formato pequeño (lanzado en los años cincuenta, iba por su vigesimoquinta edición en 1897 y mantendrá su vitalidad en el siglo XX).

Siendo esto es así, no es de extrañar que, durante la segunda mitad del siglo XIX, haya autores o editoriales que, en vez de lanzar un diccionario bilingüe para usuarios de nivel avanzado, opten de entrada por un tipo de diccionario con menores pretensiones. De todos ellos, uno de los llamados a alcanzar mayor fortuna será el de Domingo Gildo (segunda edición en 1858), publicado, como el de Salvá, también en París; los editores fueron Rosa y Bouret, los mismos que por entonces estaban publicando el Martínez López. El de Gildo y el de Salvá serán de hecho los diccionarios económicos que dominen el mercado francés y en gran parte también el español y el hispanoamericano, ya que también este último estuvo pronto en las miras de las empresas parisinas desde poco después de la independencia de las antiguas colonias españolas. El de Gildo, por su decimosegunda edición en 1890, fue revisado por Francisco Gutiérrez Brito en la de 1897, por lo que será en su nueva versión como comience su larga andadura por el siglo XX.

El dominio editorial del Salvá en pequeño formato y del Gildo no fue absoluto, sin embargo. Hubieron de compartirlo, por un lado, con los diccionarios que ya se venían editando desde la primera mitad del siglo y que siguen en el mercado durante la segunda más o menos revisados. Ya nos hemos referido a ellos al hablar de las impresiones o las adaptaciones del Taboada lanzadas desde Barcelona hasta los años ochenta. Y también se imprime por entonces en Barcelona algún diccionario que se proclama como independiente del Taboada. Es el caso del de Pedro Freixas y Sabater; de formato similar al del Taboada, aunque con un fuerte desequilibrio en número de lemas entre la primera parte, francésespañol, y la segunda, español-francés, no tuvo más que una sola edición (Barcelona, 1864). En el último tercio de siglo se añaden algunos otros. Así, desde Madrid, el Novísimo diccionario manual (1893), de Carlos Soler Arqués, obra con la que el autor completa su oferta de manuales para la enseñanza del francés en secundaria, y, previamente (1886), el de Felipe Picatoste, editado por Gregorio Estrada en la colección "Biblioteca enciclopédica popular ilustrada" (tomos 83 a 86), más concretamente en su sección de "Conocimientos útiles", en la que ya habían aparecido manuales de Física popular, Electricidad, Derecho mercantil, Telefonía, etc., además de un Diccionario popular de la lengua castellana (1882), también de Picatoste. En cuanto a los diccionarios de bolsillo aparecidos en Francia, está el Nuevo diccionario de J. Darbas y J. U. Igón ${ }^{68}$, cuya segunda edición (1896)

\footnotetext{
${ }^{68}$ Es el segundo diccionario lanzado en el siglo desde Toulouse. El primero, de Piferrer y Neira, lo imprimieron Bon y Privat en 1846 y no fue reeditado. Un miembro de la familia Privat, Édouard Privat, es también quien edita este nuevo diccionario francoespañol a finales de siglo.
} 
se presenta revisada por J. M. B. Mareca, aunque no hemos localizado ninguna edición anterior a nombre de los mismos autores. A diferencia de los diccionarios de Soler Arqués y de Picatoste, nunca reimpresos, el de Darbas e Igón lo será al menos tres veces más hasta 1910. Añadamos, por último, otros dos diccionarios de faltriquera aparecidos en el último cuarto del XIX: los publicados en uno de los grandes centros históricos de la imprenta europea, es decir, en Leipzig, fuera, pues, del territorio hispanohablante o francófono y, en cierto modo, antecedentes de la gran penetración de la editorial Langenscheidt en el ámbito de la lexicografía hispanofrancesa durante la segunda mitad del siglo XX. Nos referimos al de Louis Tolhausen, que conocerá siete impresiones entre 1884 y 1914, siempre por Tauchnitz, y al Nuevo diccionario portátil español-francés y francès-español, de Aquenza, impreso por Teubner en 1890 (al menos tal es la fecha del prólogo) y que quizá solo apareciera, pese a su título, con la parte francés-español.

También existe en el XIX una producción lexicográfica plurilingüe con el francés y el español $^{69}$. Así, el Dictionnaire abrégé et portatif (París, segunda edición en 1807) de C. de la Jonchère, con claras pretensiones de comparación entre las lenguas románicas: provisto de unos preliminares que ofrecen explicaciones en paralelo sobre los artículos, los nombres, los adjetivos... del francés, el italiano, el español y el portugués, la obra es fundamentalmente un diccionario alfabético con las entradas en francés y las equivalencias en latín y en los otros tres idiomas románicos mencionados. Más lejos llega Edme Alphonse Drouin en su Dictionnaire comparé des langues française, italienne, espagnole, latine, allemande, anglaise, grecque, hébraïque et arabe ramenées à leur unité primitive et naturelle (Caen / París, 1866), con entradas en francés y equivalencias en las lenguas indicadas con vistas a hallar la raíz de una lengua universal hebraica, una lengua que podría ser común poco a poco para todos, primero para los letrados, después para las clases medias y luego para las más humildes. Miras más didácticas tenían en cambios los políglotas editados en los años setenta: el Album-vocabulaire du premier âge en français, anglais, allemand, italien et espagnol (París, 1873) de H. Hamilton, G. Heumann y Armand Le Brun, destinado, como indica su título, a los niños, por lo que se incluyen varios centenares de ilustraciones sobre los lemas; o el Nouveau vocabulaire français, anglais, espagnol, à l'usage de l'industrie et des écoles (París, 1875), de Alfred Bazire, así como, editado esta vez en Madrid, el Nuevo prontuario y vocabulario práctico de los idiomas español, inglés y francés (1879), de Manuel Scheidnagel. Cabe citar, finalmente, algunas obras en que francés y español se encontraban reunidos en conjuntos variados de lenguas sin que ni el uno ni el otro fueran la de partida: así, el breve vocabulario de James Boardman (Londres, 1810), con entradas en inglés y columnas con las equivalencias en latín, alemán, francés, italiano, español y portugués; o The polyglot (1841) del capitán Vanwyn, con ocho idiomas (francés, alemán, inglés, ruso, polaco, español, holandés e italiano) y voces jergales del ruso y el polaco.

Mención particular nos merecen, como en el caso de los otros siglos estudiados, las obras lexicográficas que reúnen el francés y español con el vasco o el catalán. Data de 1839

\footnotetext{
${ }^{69}$ Sobre la lexicografía plurilingüe del siglo XIX, véase Cazorla Vivas (2006b).
} 
la publicación en Barcelona del Diccionari catalá-castellá-llatí-frances-italiá, redactado, según se lee en portada, "per una societat de catalans",70; se trata en realidad de un diccionario alfabético catalán completado con las equivalencias en los demás idiomas, puesto que estas solo se dan después de la definición en catalán de los lemas, también catalanes. Con todo, es el único diccionario del XIX en que el catalán, el español y el francés se ofrecen juntos, si se exceptúa el Diccionario castellano-catalán-latino-francésitaliano (Barcelona, 1842-1848), de Miquel Anton Martí, Lluís Bordas y Joan Cortada, que puede verse como una versión derivada (con los lemas en castellano) del de 1839. Bien es cierto que Antoni Febrer i Cardona compuso con anterioridad un Diccionári Menorquí, Españól, Francês y Llatí, pero no llegó a ver la luz en su tiempo ${ }^{71}$, por lo que el Diccionari de 1839 ha de contemplarse como la primera obra lexicográfica impresa que reúne el catalán, el español y el francés desde el Promptuario (1771) de Broch, por más que el carácter y la finalidad de una y otra obra poco tengan en común.

Los diccionarios políglotas con el vasco y las dos lenguas de nuestro corpus se harán esperar algo más en el siglo XIX que los que incluían el catalán. El primero del siglo fue el de Joseph-Augustin Chaho, publicado en Bayona por fascículos entre 1855 y 1857; la muerte del autor en 1858 es probablemente la causa de que este Dictionnaire basque, français, espagnol et latin quedara incompleto. De nuevo en Bayona, la ciudad históricamente más prolífica en la impresión de estas obras, aparecerá al acabar el siglo, en 1899, el modesto Vocabulaire trilingue français-espagnol-basque, de fray Juvénal-Martyr, pronto seguido, al comenzar el XX, por el Nouveau dictionnaire basque-français-espagnol, de Jean-Baptiste Darricarrère y Rafael de Murga; este, aparecido igualmente en Bayona, quedó interrumpido en la letra A, pero fue seguido a su vez por el famoso Diccionario vasco-español-francés (Bilbao, 1905-1906), de Resurrección María de Azkue.

En cuanto a la presencia junto al francés y el español de una lengua propia de otro país hispanohablante, ha de recordarse el Guide de la conversation en trois langues français, espagnol et mexicain (París, 1862), una adaptación por Charles Romey, con motivo de la aventura imperial francesa en Méjico, del Vocabulario manual de las lenguas castellana y mexicana, de Pedro de Arenas, cuya primera edición, en Méjico, data de 1611, pero con numerosas reediciones en el siglo XIX. La edición de 1862 que nos interesa contiene una nomenclatura temática trilingüe francés-español-náhuatl.

Por último, y en lo que atañe al español y el francés con alguna otra lengua de Francia, solo podemos citar el Pequeño vocabulario español, rústico de Tolosa, y francés, editado en Toulouse en 1823. Como indica su título en español o el título en francés que se lee en el reverso de la portada (Petit Vocabulaire espagnol, patois de Toulouse, et français), se trata íntegramente de un simple listado alfabético de vocablos españoles acompañados de equivalencias en occitano y francés. En cuanto a sus autores, solo se nos dice que son los de Maison rustique abrégée et hommage aux hommes vertueux, obra salida de la misma

\footnotetext{
${ }^{70}$ Según Colón \& Soberanas (1986: 162), esa “societat de catalans" la formaban Salvador Estrada, Antoni Matamala, Ferran Patxot, Joan Cortada y Lluís Bordas.

${ }^{71}$ Existe edición crítica moderna con estudio introductorio de Maria Paredes (Barcelona, Institut d'Estudis Catalans, 2001)
} 
imprenta, el mismo año, y que se presenta como compuesta "par François de Corail de Sainte-Foy [...] et par H.-B.-F.-G.-M. C., D. et A.”.

Como hemos dicho al tratar del XVIII, ya se editaron a finales de ese siglo cierto número de obras que anunciaban la explosión de diccionarios políglotos de especialidad que iba a darse en el XIX. Esto es patente, por ejemplo, en el ámbito de las voces de marina. Al comenzar la centuria (1808) vuelve a editarse el de Neuman, políglota, con las entradas en inglés y equivalencias en cinco lenguas (primera edición en 1799). Entre los bilingües francoespañoles de esa temática, el primero en fecha fue el de Charles Marie L. Lhuillier y C. J. Petit, bidireccional e impreso en París en 1810. Esta misma fecha lleva la parte español-francés del diccionario manuscrito de Lorenzo de Navas; pero, al no llegar a salir a luz, hay que esperar a 1829 para ver aparecer en Madrid la Cartilla práctica de la construcción naval, de Timoteo O’Scanlan, reimpresa en 1847. La Cartilla es un vocabulario español con sus definiciones en la misma lengua, pero incluye al final tres vocabularios alfabéticos con las entradas, respectivamente, en francés, inglés e italiano y las equivalencias en castellano. Ahora bien, O’Scanlan había sido escogido, previa presentación de una obra manuscrita terminada, para llevar a cabo el proyecto de elaborar un Diccionario marítimo español. Este proyecto había sido convocado, para paliar la falta de obras del género en España, por Real Orden de 16 de mayo de 1827; de ahí que O’Scanlan pudiera contar para su realización con todo el apoyo de la Dirección Hidrográfica, que le facilitó la consulta de buen número de obras manuscritas españolas sobre el tema, así como de cierto número de obras impresas extranjeras. Entre las manuscritas estaba el Diccionario universal de Marina (1777), de Tomás Sotuel, que ya incluía, como hemos visto, dos vocabularios bilingües, uno español-francés y otro españolinglés. El Diccionario marítimo español de O'Scanlan vio la luz finalmente en 1831, en Madrid, precedido de un largo prólogo compuesto por Martín Fernández de Navarrete, altamente instructivo en cuanto a la génesis de este proyecto y sus fuentes lexicográficas. En este diccionario, las definiciones de los lemas, en español, iban acompañados de sus correspondencias en francés, inglés e italiano, completándose la obra con tres vocabularios marítimos en dirección inversa, o sea, con las entradas, respectivamente, en cada uno de esos tres idiomas y las equivalencias en castellano; es el mismo esquema que seguirá, con las mismas lenguas, un derivado de la obra de O'Scanlan: el Diccionario marítimo español (Madrid, 1864) de José de Lorenzo, Gonzalo de Murga y Martín Ferreiro, también vinculados a la Dirección de Hidrografía. Y es también el mismo esquema que ya presentaba el Répertoire polyglotte de la marine (París, 1829), de Louis-Marie-Joseph O’Hier de Grandpré, solo que con las entradas y definiciones en francés y las correspondencias y los vocabularios en cinco lenguas (inglés, español, alemán, italiano y portugués). Poco tiempo después, en 1834, vuelve a aparecer en París un diccionario de marina con las lenguas de nuestro corpus, aunque esta vez de carácter más restringido; nos referimos al Dictionnaire abrégé de Marine de Pierre-Marie-Joseph Bonnefoux, que inserta, entre los lemas en francés y su definición, las equivalencias en inglés y español, pero no incluye los vocabularios en sentido inverso al de los lemas que completaban el Répertoire de O'Hier de Grandpré, es decir, no incluye, remitiéndonos a lo que más nos interesa, un vocabulario español-francés. Tal vocabulario será, en cambio, uno de los que formen la colección de ocho vocabularios bilingües sobre términos de la marina a vapor 
que coordinó Edmond Pâris; aparecidos en París, el correspondiente al español-francés fue compuesto por Trinidad García de Quesada (Vocabulaire espagnol-français des termes de la marine à vapeur, 1859). Poco antes, y también en el contexto del desarrollo progresivo de los barcos y máquinas de vapor, José de Carranza y Echevarría, autor del Tratado de las máquinas de vapor, aplicadas á la propulsion de los buques (Madrid, 1857), componía sus glosarios trilingües en inglés, francés y español con los términos técnicos correspondientes.

Además de en España y en Francia ${ }^{72}$, la impresión de diccionarios marítimos políglotas fue frecuente a todo lo largo del siglo en otros países; en ellos, cualquiera que sea la lengua de los lemas, pueden encontrarse reunidos el francés y el español entre las lenguas meta en que se dan las equivalencias. Tal es el caso de la obra de Neuman, a la que ya nos hemos referido, así como de las de Carl F. T. Henckel y Wilhelm F. Born (Manuel nautique ou dictionnaire de marine portatif, Copenhague, 1836), Eduard Bobrik (Allgemeines nautisches Wörterbuch, Leipzig, 1847), Karel Pieter ter Reehorst (The mariner's friend, Kampen, 1849) ${ }^{73}$, Heinrich Tecklenborg (Internationales Wörterbuch der Marine, Bremen, 1870), A. C. Littleton (Vocabulary of sea words, Portsmouth, 1879) o John C. Coxe (An illustrated nautical polyglot, Nueva York, 1883).

En el ámbito más general de lo militar, también el siglo XIX dio lugar a una lexicografía hispanofrancesa ${ }^{74}$. El primero en el tiempo fue el Diccionario militar de Federico Moretti (Madrid, 1828), que, además de brindar la equivalencia francesa en la definición en español de los lemas españoles de la obra, añadía al final un vocabulario francés-español. Lo mismo hará otro de los grandes diccionarios militares españoles del XIX, el de José Almirante (Madrid, 1869), al incorporar en anejo un vocabulario francésespañol, al que sigue en este caso otro alemán-español. Y entre el de Moretti y el de Almirante, había salido a luz el Vocabulario francés-español de términos de Artillería, y de los oficios y artes militares y civiles que tienen relación con ella (Segovia, 1848), de Pedro de la Llave. Pero habrá que esperar a 1889 para que vuelva a aparecer, esta vez en París, una nueva obra exclusivamente bilingüe: el Vocabulaire militaire espagnol-francais, de Henri Trépied; poco después, en la misma ciudad, la editorial Garnier se interesa por este tipo de diccionarios, de donde resulta el que cierra el siglo: el Diccionario militar (1897) de Nicolás Estévanez, trilingüe español-francés-alemán. En este campo, era el tercer políglota con el español y el francés que se editaba en Francia, dado que, en 1883, Édouard Gille había publicado su vocabulario militar en cuatro lenguas (francés, alemán, italiano, español) y previamente (1853) ya había sacado Joaquín María Enrile su trilingüe francésinglés-español.

\footnotetext{
${ }^{72}$ No hemos mencionado el Glossaire nautique. Répertoire polyglotte des termes de marine (1848), de Auguste Jal. Contrariamente a lo que su título en francés y su publicación en París pudieran llevar a pensar, los lemas de esta obra no siempre están en lengua francesa. Aunque organizados alfabéticamente, están constituidos por voces o expresiones de idiomas distintos para las que se proporcionan las equivalencias políglotas pertinentes.

${ }^{73}$ El mismo autor había publicado previamente (1842) su New Dictionary of Technical Terms, containing: 1. Commercial or Mercantile Terms, in seven different languages. 2. Judicial Terms, in six different languages. 3. Nautical Terms, in six different languages. 4. Denomination of Articles, in eight different languages, donde, como en The mariner's friend, los lemas de los diversos apartados temáticos van ordenados alfabéticamente por el inglés y donde el francés y español siempre aparecen entre las lenguas meta.

${ }^{74}$ Sobre la lexicografía española de lo militar, véase Gago Jover (2008).
} 
Si hay un siglo en que el recurso a las nomenclaturas o listados de vocablos repartidos por temas ha sido frecuente, ese es el XIX, principalmente gracias a su aparición frecuente en los manuales de enseñanza de idiomas extranjeros en el ámbito de los estudios secundarios $^{75}$. Suelen ser nomenclaturas bilingües, en nuestro caso francés-español o español-francés, dado que los manuales o libros de ejercicios, de traducción o de lectura en que aparecen están destinados al aprendizaje del francés por los hispanohablantes o del español por los francófonos. En este último grupo, la tradición de incorporar una nomenclatura se había ido estableciendo sólidamente a todo lo largo del siglo XVIII gracias, en gran parte, a las reediciones de los Diálogos de Sobrino; incluso la Gramática del mismo autor, que, como hemos visto, venía incluyendo un vocabulario bilingüe bidireccional, acaba por acompañarlo en las ediciones de la última década del XVIII con la nomenclatura, como también hemos explicado. No es, pues, extraño que, ya en el XIX, siglo en que dejan de publicarse los Diálogos de Sobrino, las gramáticas que siguen utilizado este nombre en sus títulos incluyan una nomenclatura. Tal es el caso de Le Nouveau Sobrino ou Grammaire espagnole-française, simplifiée et réduite à XIII leçons, de Francisco Martínez, cuya primera edición apareció en Burdeos en 1809, manteniendo su presencia en el mercado hasta más allá de pasado el meridiano de la centuria; y el caso de la Grammaire espagnole-française de Sobrino, de A. Galbán, repetidamente impresa en París desde 1861 hasta el inicio del siglo XX. Una tradición similar se instauró en las gramáticas de francés para hispanohablantes ${ }^{76}$ a partir del Arte de Chantreau, con primera edición en Madrid en 1796. Su característica nomenclatura (de la que ya nos hemos ocupado) con una primera distribución de los vocablos en adjetivos, verbos y sustantivos aparecerá tal cual o con pocas modificaciones en las muchas gramáticas que, con nombre expreso del revisor o sin él, fueron apareciendo a lo largo del XIX como reediciones o sucesoras del Chantreau primitivo. Nos estamos refiriendo, entre los chantreaus que se presentan como tales y que llevan nombre de revisor ${ }^{77}$, al Arte de Hamonière (París, 1815), al de Núñez de Taboada (París, 1824), al de Dupuy (Barcelona, 1824), a El Nuevo Chantreau de Alemany (Madrid, 1826), al Arte de Bordas (Barcelona, 1836), al Novísimo Chantreau de Puiggarí (Perpiñán, $1841)^{78}$, al de Bergnes de las Casas (Barcelona, 1845), al de Alarcón (Madrid, 1845), al Chantreau reformado de Torrecilla (París, 1850), al Arte de Galbán (París, 1863) ${ }^{79}$, a la

\footnotetext{
${ }^{75}$ Se encontrará un repertorio de los manuales para el aprendizaje del francés en España durante los siglos XVI a XIX en Fischer, García Bascuñana \& Gómez (2004). En cuanto a los manuales de español para francófonos desde 1789, véase Choppin (1995); para las gramáticas de español como lengua extranjera en general, Sánchez Pérez (1992). Para las obras lexicográficas del español no estructuradas alfabéticamente, véase Ayala Castro (1998).

${ }^{76}$ Sobre la didáctica del francés en España entre 1767 y 1936, véase Fernández Fraile \& Suso López (1999).

${ }^{77}$ En el siglo XIX, decir un Chantreau era prácticamente significar "gramática francesa para hispanohablantes", al igual que decir un Sobrino se asimiló en gran medida a "gramática de español para francófonos".

${ }^{78} \mathrm{Si}$ se da crédito a lo que asegura el autor en el prólogo de la edición de 1841, su primera versión del Chantreau apareció en Perpiñán en 1824.

${ }^{79}$ Se trata de A. Galbán, el autor asimismo, como hemos visto, del Sobrino para francófonos durante la segunda mitad del XIX.
} 
Gramática de Delgado Campos (París, 1875) ${ }^{80}$. Si se tienen en cuenta las varias o muchas reediciones que cada una de estas versiones del Chantreau tuvieron, así como las numerosas reediciones de la obra que no aparecieron con nombre de revisor, y cuyo listado excusamos, puede uno hacerse una idea más cabal de la presencia masiva de las nomenclaturas en los manuales de francés para hispanohablantes. Sobre todo si, además, se tiene en cuenta que el modelo gozaba de tanto prestigio que se extendió más o menos fielmente a autores que no presentaban sus obras como herederas directas del Chantreau ni de ninguno de sus revisores, pese a que en realidad lo eran. Ya hemos visto que el primero de estos autores fue, todavía en el siglo XVIII, Martínez Saavedra; en el XIX le seguirán otros como Galavotti, cuyo Arte (Barcelona, 1839) lleva una nomenclatura que es deudora de la del Arte de Bordas (Barcelona, 1836).

He aquí, para completar nuestra panorámica de lo que fue la importante presencia de las nomenclaturas en los manuales de francés para hispanohablantes aparecidos en el siglo XIX, un listado de autores de obras de ese tipo en las que hemos comprobado su existencia: Novella (Alicante, 1813), Bouynot (Valencia, 1815), Monfort (Valencia, 1815), Tramarría (Madrid, 1829), Laverdure (Vitoria, 1842), Domínguez (Madrid, 1844), Sauzeau (1845), Vila e Iglesias (Barcelona, 1850), Losáñez (Madrid, 1854), Llausás (Barcelona, 1855), Caze (Barcelona, 1855; Barcelona, 1867), Molfino (Málaga, 1861), Anglada \& Llausás (Barcelona, 1864), Chartrou (Alicante, 1884), Muñoz (Barcelona, 188?), Tarazona (Valencia, 1898). A ellas pueden añadirse ciertas obras que, por su carácter enteramente bilingüe, y pese a estar dirigidas primordialmente a los francófonos, podían ser de provecho similar para los hispanohablantes; por ejemplo, La nueva guía de la conversación en español y francés (París, 1815), de Hamonière, o la Guía de la conversación española y francesa (París, 1838), de Bourgoin.

Las guías de conversación presentan una fuerte afinidad con las guías de viajeros, hasta el punto de que algunas de estas últimas se dirigen expresamente tanto a quienes se trasladan a otro país como a los escolares del país donde se editan, en nuestro caso Francia; así, la Guía de la conversación español-francés al uso de los viageros y de los estudiantes (París, 1842), de Ochoa, o el Manuel de la conversation et du style épistolaire, à l'usage des voyageurs et de la jeunesse des écoles, français-espagnol, de Corona Bustamante (París, 1856). No es de extrañar, por consiguiente, que también las guías de viajeros incluyan frecuentemente nomenclaturas temáticas; es el caso de las que acabamos de citar o de Le Petit nécessaire des Français qui vont en Espagne (Montpellier, 1811), últimamente estudiada por García Aranda (2005-2006).

Algunas nomenclaturas ofrecen ciertas particularidades de presentación, es decir, aunque conforman un vocabulario bilingüe repartido por apartados temáticos, no se adecuan al modelo general de ser un listado continuado. Las hay que no se apartan de lo usual sino levemente, como la de Benavent (Madrid, 1869), con una nomenclatura en realidad continuada pero solo en las páginas pares, ya que las impares se reservan para las

\footnotetext{
${ }^{80}$ No todas las obras que reclaman en sus portadas un parentesco con el Chantreau llevan una nomenclatura; no la llevan El Nuevo Chantreau de Un Literato (Burdeos, 1817), el Ejercicio práctico de la Gramática de Chantreau de Cot (Barcelona, 1824), los Rudimentos gramaticales en francés y en español extractos de la Gramática de Chantreau, también de Cot (Barcelona, 1825) o El nuevo Chantreau de Diéguez (Barcelona, 1899).
} 
explicaciones gramaticales. Otras están más claramente compartimentadas: las de Burgell (Barcelona, 1867) o Roques (Madrid, 1896) van intercalando sus diversos apartados temáticos entre la materia general de la obra, de modo que cada uno aparece como el vocabulario que conviene ir aprendiendo conforme se adquiere mayor dominio de la lengua. Es lo que hacen también González Pereira (Madrid, 1883) y Galicia Ayala (Valladolid, 1883), que incluso aprovechan los apartados que se insertan en las lecciones sobre los sonidos del francés para añadir una tercera columna de pronunciación figurada a la doble columna francés-español de vocabulario temático. Con la pronunciación aparecen también las columnas de la nomenclatura que hay en la Novísima guía de conversaciones modernas ó diálogos usuales y familiares en español y en francés (Madrid, s. a.), de Ochoa, cuyos distintos apartados están además separados entre sí por frases propias de la conversación para practicar los vocablos correspondientes al apartado que precede. En esta supeditación de la nomenclatura al material del resto de la obra, nada impide que hasta los contornos de los distintos epígrafes se desdibujen; Galicia Ayala, por ejemplo, aun manteniendo unidos los vocablos de cada bloque semántico, pasa a veces de un apartado a otro sin que nada lo avise formalmente. Hay, por último, algún autor que combina en una misma obra el tratamiento de la nomenclatura como listado continuado y su tratamiento como bloques separados; Moralejo (París, 1862 [1835]), por ejemplo, presenta primero treintaiún apartados temáticos, cada uno seguido de sus correspondientes ejercicios de empleo en contexto, pasando luego a una nomenclatura clásica en su presentación, o sea, formando un listado léxico continuo, solo interrumpido por los epígrafes de cada grupo semántico.

Las nomenclaturas bilingües del XIX a que nos hemos referido hasta ahora forman una parte minoritaria de las obras en que se hallan incluidas. Pero también en este siglo se editaron algunas obras cuyo contenido mayoritario está constituido básicamente por una nomenclatura. Su número es prácticamente insignificante si se compara con el de las muchas a las que nos hemos referido hasta ahora, pero cabe, con todo, recordar las bilingües de Beaume (Vocabulaire français-espagnol, Burdeos, 1809) y de Lanquine \& Baro (Les mots espagnols groupés d'après le sens, París, 1896), ambas dirigidas primordialmente a francófonos, o las políglotas para hispanohablantes de Frutos (Diccionario manual de voces necesarias para el trato común en las cinco lenguas española, italiana, francesa, inglesa y latina, Madrid, 1804) o de Aínsa y Royo (Nuevo vocabulario de los idiomas modernos español, inglés, francés e italiano, Barcelona, 1837).

Como se ve y ya decíamos previamente, es considerable el desarrollo y la variedad que alcanzan las nomenclaturas en el siglo XIX. Y ello pese a que no nos hemos ocupado de las nomenclaturas políglotas de las guías de viajeros (son bilingües las que hemos mencionado) o de aquellas que, como en otros siglos, se pueden rastrear en diálogos o en conjuntos de enunciados relativos a un tema determinado, lo cual cuenta ya con los lejanos precedentes de los coloquios del XVI o de la Ianua linguarum quadrilinguis (1617) de William y John Bathe o la Ianua linguarum reserata quinque linguis (1661) de Comenio. A este último respecto, y para el siglo XIX, pueden consultarse, por poner un ejemplo entre muchos, los veintiocho diálogos o "entretiens familiers entre un Espagnol et un Français" del Compendio (Barcelona, 1829) de Dupuy. Existe incluso algún caso mixto en que un vocabulario temático al uso acaba convirtiéndose en una nomenclatura cuyos vocablos se contextualizan en frases sobre un tema común; así, en la Gramática francesa de Lhomond 
(Madrid, 1821) editada por Letellier y Sánchez Ribera se incluye una "Coleccion de las palabras y modos de hablar mas usuales de las Lenguas Francesa y Española" que es curiosa: entre las páginas 364 y 367 se presenta al modo tradicional, pero en 367-370 se transforma, ya sin epígrafes que lo anuncien, en un conjunto de frases simples (verbosustantivo, luego verbo-adjetivo) sobre los vestidos y las comidas, para desembocar (páginas 370 a 411) en diálogos temáticos. Si lo citamos es como simple ejemplo de lo difuminadas que pueden ser las fronteras entre las verdaderas nomenclaturas, que, pese a su carácter didáctico, hemos considerado como propias del campo lexicográfico, y otros recursos de la didáctica de las lenguas.

En este mismo sentido, es preciso recordar que la adquisición del vocabulario se potenciaba en muchos métodos de francés para hispanohablantes o de español para francohablantes por medio de las prácticas didácticas más extendidas en la época: la de la versión-traducción o la de lectura de trozos escogidos. A menudo, las palabras empleadas en tales ejercicios se recogían tras cada uno de ellos, pero también podían aparecer recopiladas, lo cual es de mayor interés para nuestro estudio, al final de la obra con el objetivo de que el alumno no tuviera que estar recurriendo constantemente a un diccionario. En tal caso, se ofrecen verdaderos listados o vocabularios bilingües ordenados por orden alfabético. Es lo que se halla, entre las obras de francés para hispanohablantes, en las de Cormon (Lyon, 1810), Gaytté (Madrid, 1848), Caze (Barcelona, 1861), Madame de SaintPaul (Barcelona, 1840), García de Modino (Valladolid, 1866), Soler y Arqués (Vich, 1866; Madrid, 1884), Benavent (Madrid, 1869) ${ }^{81}$, Mac-Veigh (Madrid, 1872 [1857]), García Ayuso (Madrid, 1879), Troullioud (Madrid, 1884), Laverdure (Oviedo, 1887 [1859]), Olavarrieta Lacalle (Reus, 1895), Champsaur (Palma de Mallorca, 1898). De carácter comercial son los de Bergnes de las Casas (Barcelona, 1883 [1845]) o Melzi (París, $1878)^{82}$.

En ciertos casos, estos vocabularios alfabéticos se parecían bastante a diccionarios elementales, ya que ocupaban la mayor parte de las obras en que aparecían y no estaban supeditados a que los vocablos recopilados fueran los que aparecieran en otros apartados de las mismas, todo ello independientemente de que algún autor pudiera considerar tal género de vocabulario como como un complemento a otras obras suyas destinadas también a la enseñanza. Uno de los casos más evidentes de ello es el Vocabulario franco-español y español-francés (Sevilla, 1894), de Vilar y García, que, con sus casi quinientas páginas, se editó precedido de unos Elementos de Fonética y Lexicología de unas sesenta páginas.

Como en el caso de los límites de las nomenclaturas, no siempre está clara la frontera entre los vocabularios alfabéticos de carácter lexicográfico y los listados de palabras que

\footnotetext{
${ }^{81}$ Como es el caso en esta obra de Benavent, nada impide que los listados alfabéticos coexistan en un mismo manual con otros de carácter temático.

${ }^{82}$ Los vocabularios que se incluyen en los manuales pueden ser de formatos muy variados, es decir, no se limitan a los modelos de la nomenclatura temática o el listado alfabético. Antony (1893), por ejemplo, completó su Método con la publicación posterior de un Apéndice de 44 páginas ocupado casi enteramente por diecisiete vocabularios francés-español correspondientes a los temas de traducción de dicho Método; en esos vocabularios, las entradas pueden ser de cualquier categoría gramatical, palabras simples o locuciones, infinitivos o verbos conjugados, etc., todo ello siguiendo sencillamente el orden de su aparición en el ejercicio de traducción de referencia.
} 
persiguen un objetivo distinto del de la simple recopilación de vocablos. En todo caso, hemos excluido de nuestro centro de interés actual los frecuentísimos listados alfabéticos que son, en las obras donde aparecen, una ilustración de las explicaciones sobre pronunciación y prosodia (Grimaud 1826, por ejemplo, con sus listados de palabras repartidas según su número de sílabas), morfología (Cormon, 1804, por ejemplo) o cualquier otro aspecto. Precisamente el Chantreau y sus muchos derivados son buen ejemplo de la inclusión, no solo de nomenclaturas, sino de nutridos listados alfabéticos, bilingües y bidireccionales, que recogían gran número de palabras españolas y francesas cuya característica común era que sus diversas acepciones no se traducían siempre por la misma voz al otro idioma. Este tipo de vocabularios hizo gran fortuna en toda clase de manuales de enseñanza de lenguas durante el XIX, siendo frecuente que se encuentren también en obras que no ofrecen ni listados alfabéticos puramente lexicográficos ni nomenclaturas temáticas (véanse, por ejemplo, Delaborde 1855 o Bordas 1856).

\section{ConClusión}

En la historia de la producción lexicográfica bilingüe español-lengua extranjera, la hispanofrancesa es la más rica. Reunidos primeramente en obras de carácter políglota, y conforme a una evolución similar a la conocida por otros pares de lenguas en nuestro campo, el español y el francés fueron encontrándose en diccionarios bilingües cada vez con mayor frecuencia; pero, como hemos intentado resaltar en este trabajo, el bilingüismo lexicográfico progresivamente triunfante nunca llevó a la desaparición de la presencia conjunta de ambas lenguas en obras políglotas. Pese al desarrollo del bilingüismo lexicográfico francoespañol, asentado ya en sólidos cimientos durante el XVII y con consistente fortaleza duradera a partir del siglo XVIII, el plurilingüismo lexicográfico encontró nuevas vías de desarrollo en ámbitos como el de las ciencias y las técnicas o el de las guías de viajeros. Tras los grandes diccionarios bilingües puros del XVII y la primera mitad del XVIII, vuelven a imponerse en la segunda mitad de este último siglo los bilingües hispanofranceses con apoyo de equivalentes latinos, retornándose finalmente al bilingüismo estricto en el XIX. Los diccionarios trilingües con el francés, el español y otra lengua viva, de tan fuerte presencia en el siglo XVII, desaparecen prácticamente luego, si bien se conservan testigos, que hemos intentado destacar, en los vocabularios y diccionarios con el catalán, el vasco o, en menor medida, alguna otra lengua propia de los territorios hispano o francohablantes.

También hemos procurado incidir en la constante existencia de dos modos de ordenación del léxico en la producción lexicográfica histórica: el alfabético y el temático. Si el modo alfabético dio lugar a los grandes diccionarios, el temático, tras favorecer la aparición de importantes nomenclaturas multilingües y bilingües en los siglos XVI y XVII, fue evolucionando cada vez más -sobre todo desde el XVIII, pero con casos anteriores- a un tratamiento de las nomenclaturas, ya predominantemente bilingües, como suplemento de las obras gramaticales para el aprendizaje del español o el francés, hasta que se conviertan en muchos manuales escolares del XIX en un mero apoyo, más o menos secundario, para el aprendizaje del vocabulario básico de la lengua meta; unos manuales, por otra parte, que tampoco desaprovecharon la posibilidad de recoger en glosarios alfabéticos el vocabulario 
empleado en la obra, ofreciendo así una alternativa cómoda y rápida a la consulta o la compra de los diccionarios.

Precisamente el esfuerzo empresarial de impresores y libreros por ganar clientela para su producción lexicográfica llevó a la aparición, a finales del XVIII, de los primeros diccionarios portátiles, mucho más manejables que los grandes volúmenes de diccionarios como el de Séjournant o el de François Cormon. Ahora bien, también en este ámbito se impuso la doble vía: la multiplicación de las propuestas de diccionarios de bolsillo en el XIX, su preponderancia triunfante durante la primera mitad del siglo, no impidió la aparición, hacia mediados de la centuria, de un tipo de diccionario bilingüe de mayor envergadura que los jamás conocidos hasta entonces: los de carácter enciclopédico. Uno y otro modelo de diccionario bilingüe se desarrollarán así paralelamente, adaptado cada uno a un público diferente, durante toda la segunda mitad del XIX. No nos cabe duda de que los grandes promotores de estos y otros cambios históricos en nuestro corpus fueron muy a menudo, no los lexicógrafos propiamente dichos o no exclusivamente ellos, sino, de manera preeminente, los empresarios del negocio editorial, lo que no excluye que algunos de estos fueran al mismo tiempo grandes lexicógrafos. De esa convicción nace el que hayamos intentado no desatender este aspecto de la historia de la lexicografía francoespañola en los forzosamente breves comentarios que hemos ido dedicando a las obras que la configuran, si bien por esa misma brevedad no hemos podido pararnos en todos los casos que hubieran admitido una observación a este respecto, como no lo hemos hecho en todos los casos que hubieran admitido una explicación, por ejemplo, sobre fuentes e influencias.

El límite posterior que hemos puesto a este recorrido histórico de la lexicografía francoespañola viene dado por la temática propia de este número, pero nada significa en la configuración y evolución real de nuestro corpus. Lo que era válido a finales del siglo XIX seguirá siéndolo a principios del XX, a la espera, por supuesto, de las novedades que siempre aportan los nuevos tiempos. Solo nos queda, pues, esperar tener la oportunidad de poder ocuparnos en una próxima ocasión de ampliar hacia adelante, hacia su prolongación cronológica natural, el panorama aquí trazado. 


\section{REFERENCIAS BIBLIOGRÁFICAS}

\section{Fuentes primarias citadas}

\section{a) Repertorio lexicográfico francoespañol}

AGuSTí, M. (1617). Llibre dels secrets de agricultura, casa rústica y pastoril, Barcelona, E. Liberós. Reediciones citadas: 1526 (Libro de los secretos de Agricultura, Casa de Campo y Pastoril. Traduzido de lengua Catalana en Castellano por Fr. Miguel Agustin [...] del Libro que el mesmo Autor saco a luz año 1617, y agora con addicion del Quinto Libro, y otras curiosidades; y vn Vocabulario de seys Lenguas, por declaracion de los vocablos de dicho Libro, \&c., Perpiñán, L. Roure), 1781 (Madrid, J. Ibarra).

Aínsa y Royo, M. (1837). Nuevo vocabulario de los idiomas modernos Español, Inglés, Francés, e Italiano, Barcelona, M. Borrás.

AlARCón, J. (revisor) (1845). Novísimo Chantreau o completa gramática francesa, Madrid, J. Viana Razola.

Aldrovand, U. (1599). Ornithologiae, hoc est de Auibus historiae libri XII, Bolonia, F. Franceschi.

Aldrovand, U. (1621). Quadrupedum omnium bisulcorum historia, Bolonia, G. Tamburini.

Alemany, L. de (1826). Gramática francesa titulada El Nuevo Chantreau. Reformada, corregida, aumentada y arreglada á los progresos del idioma, en las lecciones de D. Francisco Tramàrria, Madrid, Aguado.

AlmiRAnte, J. (1869). Diccionario militar etimológico, histórico, tecnológico, con dos vocabularios francés y alemán, Madrid, Depósito de la Guerra.

Alsinet, M. (h. 1760). Dictionarium novem linguis (latín, griego, hebreo, francés, italiano, alemán, español, inglés, catalán), ms. 1822 de la Univ. de Barcelona.

AlunNo, F. (1543). Le ricchezze della lingua volgare, Venecia, A. Manuzio.

Álvarez PATO, A. (1793). Diccionario de los nombres propios de hombres y mugeres, en las quatro lenguas Castellana, Latina, Francesa é Italiana, Madrid, Imprenta Real.

ANDREE, J. (1725). A Vocabulary in six Languages: viz. English, Latin, Italian, French, Spanish, and Portuguese, Londres, P. Vaillant, W. Meadows.

AngladA, F., J. Llausás (1864). Curso teórico y práctico de la lengua francesa Barcelona, Verdaguer.

Antony, L. (1893). Método práctico de francés para estudiarlo solo y Apéndice al Método, Valencia, J. M. Alpuente.

AQUENZA, J. (1890). Nuevo diccionario portátil español-francés y francés-español, Leipzig, B. G. Teubner.

ARENAS, P. de (1611). Vocabulario manual de las lenguas castellana, y mexicana, Méjico, H. Martínez. Reediciones citadas: 1862 (Guide de la conversation en trois langues 
français, espagnol et mexicain contenant [...] un vocabulaire des mots les plus usuels [...] revu et traduit en français par $M$. Charles Romey, París, Maisonneuve et $\mathrm{C}^{\mathrm{ie}}$ ).

AZKUE, R. M. de (1905-1906). Diccionario vasco-español-francés, Bilbao, s. n.

BATHE, W. y J. (1617 [1611]). Ianua linguarum, quadrilinguis, or A Messe of Tongues: Latine, Englishe, French, and Spanish, Londres, M. Lownes.

BAZIRE, A. (1875). Nouveau vocabulaire français, anglais, espagnol, à l'usage de l'industrie et des écoles, París, F.-E. André-Guedon.

BEAume, P. (1809). Vocabulaire Français-Espagnol à l'usage des deux Nations, Burdeos, P. Beaume.

BENAVEnt, E. (1869). El idioma francés puesto al alcance de los españoles, Madrid, hijos de Vázquez.

BERGNes de las CASAS, A. (revisor) (1845). Novísimo Chantreau o Gramática francesa. Barcelona: Juan Oliveres.

Bergnes de las CASAS, A. (1883 [1845]). Crestomatía francesa, [...] aumentada por D. R. T. C., Barcelona, J. Oliveres.

BELA, J.-Ph., (s. XVIII). [Diccionario políglota francés-vasco-griego-céltico-árabe-latíngótico-alemán-español-italiano], manuscrito.

BERBRUGGeR, L.-A. (1829). Nuevo diccionario de faltriquera español-francés y francésespañol, París, Baudoin.

BERLAIMONT, N. de (1536). Vocabulaire pour apprendre legierement à bien lire, escripre, et parler François et Flameng, Amberes, W. Vorsterman. Reediciones citadas: 1551 (Vocabulario de quatro lenguas, Tudesco, Frances, Latino, y Español, Lovaina, B. Gravio), 1642 y 1647 (véase P. Lacavallería).

BoArdman, J. (1810). A Vocabulary in the English, Latin, German, French, Italian, Spanish Portuguese Languages, Londres, s. n.

BOBRIK, E. (1847). Allgemeines nautisches Wörterbuch mit Sacherklärungen; Deutsch, Englisch, Französisch, Spanisch, Portugiesisch, Italienisch, Schwedisch, Dänisch, Holländisch, Leipzig, Verlagsbureau.

Bonnefoux, P.-M.-J. (1834). Dictionnaire abrégé de Marine, contenant la traduction des termes les plus usuels, en anglais et en espagnol, París, J.-A. Dezauche \& Bachelier; Le Havre, C.-B. Matenas.

Bordas, L. (revisor) (1836). Arte de hablar bien francés, o Gramática completa, por D. Pedro Nicolás Chantreau, Barcelona, Manuel Saurí.

Bourgoin, P. M. F. (1838). Guía de la conversación española y francesa, París, viuda de Thiériot.

Bourgoing, J. (1583). De origine, usu, et ratione vulgarium vocum linguae Gallicae, Italicae, \& Hispanicae, París, E. Prevosteau.

BouYnot, M. (1815). Lecciones prácticas ó nuevo método para aprender el idioma francés, Valencia, Manuel Muñoz \& $C^{a}$. 
Broch, J. (1771). Promptuario trilingue en el que se manifiestan con toda claridad todas las vozes que generalmente sirven para el Comercio Politico, y sociable en los tres Idiomas, Cathalan, Castellano, y Francés; à fin que los poco instruidos en algunos [sic] de los dos primeros, entren con menos dificultad à la intelligencia del tercero, Barcelona, P. Campins.

Burgell, R. (1867). Novísimo método práctico-teórico para aprender la lengua francesa, Barcelona, N. Ramírez y Compañía.

CAlEPINO, A. (1502). Dictionarium Latinarum et Grecopariter derivantium, Reggio Emilia, D. Bertocchio. Reediciones citadas: 1559 (Dictionarium [...] Adiecimus etiam Latinis Graecisque vocibus Italicas ac Hispanicas interpretationes [...], Lyon, herederos de S. Gryphius), 1565 (Dictionarium [...] adiunctae sunt praeterea singulis vocibus Latinis Italicae, Gallicae \& Hispanicae interpretationes [...], Lyon, T. Payen), 1778-1779 (Padua, J. Manfré).

CAPMANY, A. de (1805). Nuevo diccionario francés-español, Madrid, Sancha. Reediciones citadas: 1817 (Madrid, Sancha).

CARRANZA Y ECHEVARRÍA, J. de (1857). Tratado de las máquinas de vapor, aplicadas á la propulsion de los buques, Madrid, J. Martín Alegría.

CAVANILles, A. J. de (1795-1798). Observaciones sobre la historia natural, geografia, agricultura, población y frutos del Reyno de Valencia, Madrid, Imprenta Real.

CAZE, A. (1855). Curso de idioma francés teórico práctico para uso de los Españoles, Barcelona, F. Granell.

CAZE, A. (1861, $2^{\mathrm{a}}$ ed.). Maestro de francés teórico-práctico para uso de los españoles, en 85 lecciones, Madrid, Librería Española; Barcelona, Librería de El Plus Ultra.

CAZE, A. (1867). Guía de la conversación para uso de los españoles que aprenden el idioma francés, Barcelona, Librería de El Plus Ultra.

Chано, J.-A. (1855-1857). Dictionnaire basque, français, espagnol et latin, Bayona, P. Lespès.

Champsaur, B. (1898). Crestomatía francesa, Palma de Mallorca, F. Soler.

Chantreau, P.-N. (1781). Arte de hablar bien Frances, Madrid, A. de Sancha. Reediciones citadas: 1797 (Madrid, A. de Sancha). Otras reediciones citadas: véanse por el nombre del revisor.

Chartrou, L. (1884 [1864]). Recueil littéraire o Prosa y Verso para el estudio de la lengua francesa en los Institutos y Colegios de España, Alicante, Costa y Mira.

COMEnIO, J. A. [J. A. Kommensky] (1661). Janua linguarum reserata quinque linguis, sive compendiosa methodus Latinam, Gallicam, Italicam, Hispanicam \& Germanicam linguam perdiscendi sub titulis centum, periodis mille comprehensa et vocabulis mille ad minium aucte, cum quintuplice indice a Nathanaele Duesio in idioma gallicum et italicum translata et in hac tertia editione accurate emendata atque correcta cum interpretatione hispanica, Ámsterdam, L. y D. Elzevier.

CORAIL DE SAINTE-Foy, F. de, et alii (1823). Pequeño vocabulario español, rústico de Tolosa, y francés, Toulouse, viuda Tislet. 
CONTAUT, P. (1763). Gramatica Española y Francesa, novissimo selecto methodo para aprender a hablar con perfeccion el Idioma Francès, segun reglas ajustadas al Español, y faciles à los principiantes, Madrid, Imprenta del Diario.

CORMOn, F. (1769). Nouveau dictionnaire de Sobrino, François, Espagnol et Latin / Sobrino aumentado o Nuevo diccionario de las lenguas Española, Francesa y Latina, Amberes, hermanos De Tournes. Reediciones citadas: 1789 (Amberes, Piestre \& Delamollière), 1791 (Lyon, J. B. Delamollière).

CORMON, J.-L.-B. (1800). Diccionario portátil y de pronunciacion, español-frances y frances-español, Lyon, Cormon, Blanc, Reymann. Reediciones citadas: 1803 (Lyon, B. Cormon \& Blanc).

Cormon, J.-L.-B. (1810). Gramática Francesa, al uso de los Españoles, Lyon, J. L. B. Cormon \& Blanc.

Corona Bustamante, F. (1856). Manuel de la conversation et du style épistolaire, à l'usage des voyageurs et de la jeunesse des écoles, français-espagnol, París, Garnier.

Corona Bustamante, F. (1882-1901). Diccionario francés-español [español-francés] basado en la parte francesa sobre el gran diccionario de E. Littré y en la parte española sobre el Diccionario de la lengua castellana, París, Hachette y Cía

COXE, J. C. (1883). An illustrated nautical polyglot [...] in six different languages as follows: English, Spanish, Italian, Scandinavian, German and French, Nueva York, C. L. Coxe.

DARBAS, J., J. U. IGÓN (1896). Nuevo diccionario francés-español y español-francés [...]. Segunda edición revisada y corregida por J. M. B. Mareca, Toulouse, E. Privat. Reediciones citadas: 1910 (Toulouse, Privat).

DARricARrere, J.-B., R. de MURGA (1900). Nouveau dictionnaire basque-françaisespagnol, Bayona, Lamaignère.

Decimator, H. (1580). Sylva vocabulorum et phrasium, sive Nomenclator, Leipzig, Defnerus. Reediciones citadas: 1596 (Leipzig, M. Lantzenberger, H. Gross), 1606 (Sylva vocabulorum et phrasium, sive Nomenclator octo linguarum, Wittenberg / Leipzig, H. Gross).

Delgado Campos, J. (revisor) (1875). Gramática francesa [...]. Por P. N. Chantreau, París, hermanos Garnier.

DICCIONARI (1839). Diccionari catalá-castellá-llati-frances-italiá, Barcelona, J. Torner.

DiCCIONARIO (1718). Diccionario de las dos lenguas espanyola, y francesa, ms. del Centre de Lectura de Reus.

Dioscórides AnAZARBeO, P. (1636). Acerca de la materia medicinal, y de los venenos mortiferos. Traduzido de lengua Griega, en la vulgar Castellana: y illustrado con claras y sustantiales Anotaciones, y con las figuras de innumerables plantas exquisitas, y raras, por el Doctor Andres de Laguna, Valencia, M. Sorolla. Reediciones citadas: 1553 (In Dioscoridis Anazarbei de medica materia libros quinque, Amati Lusitani [...] enarrationes eruditissimae, Venecia, G. Scotum).

Domínguez, R. J. (1844). Nueva gramática francesa, Madrid, T. Aguado y Cía. 
Domínguez, R. J. (1845-1846). Diccionario universal francés-español y español-francés, Madrid, viuda de Jordán e hijos (tomo I), R. J. Domínguez (tomos II-VI). Reediciones citadas: 1853-1854 (Madrid, Mellado).

Domínguez, R. J. (1846). Diccionario de bolsillo, español-francés y francés-español, Madrid, viuda de Jordán e hijos.

DrouIn, E. A. (1866). Dictionnaire comparé des langues française, italienne, espagnole, latine, allemande, anglaise, grecque, hébraïque et arabe ramenées à leur unité primitive et naturelle, Caen, Nigault de Prailauné; París, Latouche.

DuPUIS, C., sieur des Roziers (1659). La Grammaire Espagnole, París, [s. n.].

DuPUY, P. (revisor) (1824). Arte de hablar bien francés o gramática completa $[\ldots]$ por P. N. Chantreau, Barcelona, F. Oliva.

DupuY, P. (1829). Compendio elemental de las diferencias más notables entre Francia y España, ó Conversaciones familiares entre un español y un francés, acerca de las lenguas, usos, producciones, etc. de ambos países, Barcelona, J. Verdaguer.

ENRILE, J. M. (1853). Vocabulario militar francés, inglés, español, París, H. Vrayet de Surcy.

Estévanez, N. (1897). Diccionario militar, con un vocabulario español-francés-alemán, París, Garnier.

ETXEBERRI, J. (h. 1710). [Esbozo de diccionario cuatrilingüe vasco-latín-francés-español], manuscrito perdido.

Febrer i CARDOnA, A. (s. XIX). Diccionári Menorquí, Españól, Francês y Llatí, manuscritos de las bibliotecas Victory de Febrer y Vidal i Mir de Mahón. Editado con estudio introductorio por Maria Paredes (2001), Barcelona, Institut d'Estudis Catalans.

FERNANDEZ, M. (1647). Instruction Espagnole accentuee pour les maîtres, \& pour ceus qui desirent d'apprendre parfaitement à prononcer et ècrire l'Espagnol, avec un Nomenclator, Colonia, A. Bingen.

FERnÁNDEZ Cuesta, N. (1885-1887). Diccionario de las lenguas española y francesa comparadas, Barcelona, Montaner \& Simón.

FERRUS, le sieur (1680). Nouvelle grammaire espagnole [...]. Avec un ample vocabulaire des choses les plus communes et usitées dans le discours familier, Ámsterdam, D. Elzevier.

Finestres i De Monsalvo, D. (s. XVIII). [Diccionario de cinco lenguas (latín, español, francés, catalán, griego, italiano)], manuscrito perdido.

FONSECA, J. da (1840). Dictionnaire français-espagnol et espagnol-français, Avec la nouvelle orthographe de l'Académie espagnole ; rédigé d'après Gattel, Sobrino, Nuñes [sic] de Taboada, Trapani, etc.; l'Académie française, Boiste, Laveaux, etc., París, Thiériot.

FREIXAS Y SABATER, P. (1864). Nuevo diccionario francés-español español-francés, Barcelona, Imprenta de El Porvenir. 
FRUTOS, J. de (1804). Diccionario manual de voces necesarias para el trato común en las cinco lenguas española, italiana, francesa, inglesa y latina, Madrid, Gómez Fuentenebro y Compañía.

Galavotti, G. L. (1839). Arte de hablar y escribir en francés correctamente, Barcelona, Brusi.

Galban, A. (1861). Grammaire espagnole-française de Sobrino, París, Garnier.

GAlBÁn, A. (revisor) (1863). Arte de hablar bien francés, o gramática completa [...] por Don Pedro Nicolás Chantreau, París, Garnier.

Galicia Ayala, J. (1883). Gramática francesa y Método teórico-práctico, Valladolid, hijos de Rodríguez.

GALMACE, A. (1748). Llave nueva, y universal, para aprender con brevedad, y perfeccion la Lengua Francesa, Madrid, G. Ramírez.

GARCÍA AyUSO, F. (1879). Gramática francesa, Madrid, Aribau y Ca .

GARCÍA DE MODINO Y CAMARERO, J. (1866). Versiones francesas graduadas, Valladolid, hijos de Rodríguez.

GARCIA DE QUESADA, T. (1859). Vocabulaire espagnol-français des termes de la marine à vapeur, París, A. Bertrand.

Gattel, C.-M. (1790). Nouveau dictionnaire Espagnol et François, François et Espagnol, avec l'interprétation Latine de chaque mot, Lyon, hermanos Bruyset. Reediciones citadas: 1803 (Diccionario Español-Frances y Frances-Español, con la interpretacion Latina de todas las voces, Lyon, Bruyset aîné et Comp.).

Gattel, C.-M. (1798). Nuevo diccionario portatil Español y Frances, París, Bossange, Masson, Besson. Reediciones citadas: 1798 (Valencia, P. J. Mallén y C. ${ }^{\text {) }}$, 1806 (París, Bossange, Masson, Besson).

GAYTTÉ, É. (1848). Glosología francesa que contiene [...] Un pequeño Diccionario de cuantos términos encierra la obra, Madrid, J. Martín Alegría.

GESNER, C. (1551-1587). Historia animalium, Zúrich, C. Froschauer (cinco vols.: Historiae animalium liber I: De quadrupedibus viviparis, 1551; II: De quadrupedibus oviparis, 1554; III: De avium natura, 1555; IV: De piscium \& aquatilium animantium natura, 1558; V: De serpentium natura, 1587).

GILDO, D. (1858, $2^{\mathrm{a}}$ ed.). Diccionario francés-español y español-francés. París, Rosa \& Bouret. Reediciones citadas: 1890 (París / Méjico, Bouret), 1897 ([...] Enteramente refundida, con arreglo al Diccionario francés de Larousse y al español de la Academia, por Francisco Gutiérrez Brito [...], París / Méjico, viuda de Ch. Bouret).

GILle, É. (1883). Vocabulaire militaire / Militär Conversations Buch / Vocabolario militare / Vocabulario militar, París / Dijon, Renaud.

Godoy, D. A. (1795). Diccionario nuevo portátil y manual francés-español, Bolonia, G. Franceschi.

GonzÁlez de MendozA, N. (1761-1763). Diccionario general de las dos lenguas Española, y Francesa, Madrid, Andrés Ortega. 
GonzÁlez Pereira, J. (1883). El maestro popular ó el frances sin maestro, Madrid, sucesores de Rivadeneyra.

GRIMAUd DE VElaunde, F. (1825). Nuevo diccionario portátil español-frances ó Compendio del diccionario grande de Nuñez de Taboada, mucho mas aumentado que la edicion impresa en Paris en 1823, Madrid, Ph. Denné.

GuIlla RuBí, A. S. (1707). Forma gramatical, la qual contiene el modo como se ha de aprender à leer, y hablar la lengua Francesa, Madrid, A. Fernández.

Hamilton, H., G. Heumann, A. Le Brun (1873). Album-vocabulaire du premier âge en français, anglais, allemand, italien et espagnol, París, Furne-Jouvet.

HAMONiÈRE, G. (revisor) (1815). Arte de hablar bien francés o gramática completa, por D. P. N. Chantreau, París, P. Smith.

HAMOniÈRe, G. (1815). La nueva guía de la conversación en español y francés, París, T. Barrois.

Hamonière, G. (1820). Diccionario de Faltriquera, Francés-Español y Español-Francés, París, T. Barrois fils.

Henisch, G. (1616). Thesaurus linguae et sapientiae Germanicae [...] Adiectae sunt quoque dictionibus plerumque Anglicae, Bohemicae, Gallicae, Graecae, Hebraeicae, Hispanicae, Hungaricae, Italicae, Polonicae, Augsburgo, David Franck.

HENCKel, C. F. T., W. F. BORN (1836). Manuel nautique ou dictionnaire de marine portatif pour marins, commerçants et voyageurs, conçu en huit langues, savoir: en anglais, français, danois, allemand, suédois, hollandais, espagnol et italien, pourvu d'une énumération des marchandises principales en 11 langues [...], Copenhague, Berling.

Herrero y RUBIRA, A. M. (1743-1744). Diccionario universal francès, y español, Madrid, Imprenta del Reino.

HERVÁS y PANDURO, L. (1787). Vocabolario poliglotto con prolegomeni sopra più di CL lingue, Cesena, G. Biasini.

Hornkens, H. (1599). Recueil de Dictionaires Francoys, Espaignolz et Latins. / Recopilacion de Dictionarios Franceses, Españoles y Latinos, Bruselas, R. Velpius.

Howell, J. (1659). Vocabulario particular, ô Nomenclatura Española, Inglese, Italiana, Francese, Londres, Th. Leach. Sigue en el mismo vol. a Howell (1660).

Howell, J. (1660). Lexicon Tetraglotton. Vocabulario Español-Inglès-Italiano-Francès: Al qual se há añadido una Nomenclatura en todas las dichas lenguas, Londres, Th. Leach.

HUILlery, F. (1661). Vocabulario para facilmente y brieuemente deprender a ler [sic], escrebir, y hablar la lengua Castellana, París, P. Variquet.

JAL, A. (1848). Glossaire nautique. Répertoire polyglotte des termes de marine, París, F. Didot.

JONCHERE, C. de la (1807). Dictionnaire abrégé et portatif des langues française, latine, italienne, espagnole et portugaise [...]. Deuxième édition, París, D. Colas \& Lenormant. 
Julliani, B.-C. (1659). Nomenclature du sieur Julliani, qui contient les mots exacts et choisis pour apprendre les langues françoises, italiennes, et espagnoles, París, J.-B. Loyson.

JUNIUS, H. (1567). Nomenclator omnium rerum propria nomina variis linguis explicata indicans, Amberes, C. Plantin. Reediciones citadas: 1602 (Nomenclator octilinguis omnium rerum propria nomina continens, Ginebra, J. Stoer), 1620 (Nomenclator, omnium rerum propria nomina, septem diversis linguis explicata, indicans, Fráncfort del Meno, E. Emmel).

JUVENAL-MARTYR (1899). Vocabulaire trilingue français-espagnol-basque, Bayona, A. Lamaignère.

KRAMER, M. (1711). Gramatica y sintaxe de la lengua Española-Castillana, Núremberg, J. Zieger.

Lacavallería, P. (impresor) (1642). Dictionario Castellano - Dictionaire François Dictionari Catala, Barcelona, P. Lacavallería. Reediciones citadas: 1647 (Barcelona, A. Lacavallería).

LANDUChIO, N. (s. XVI). Dictionarium Linguae Franconiae, Biblioteca Nacional de España, ms. 8431.

LANQuine, J., B. BARO, (1896). Les mots espagnols groupés d'après le sens, París, Hachette.

LAVErdure, G. J. E. (1842). El Maestro Francés, o sea Gramática Franco-Española, Vitoria, Egaña y Comp.

LAVERDURE, G. J. E. (1887 [1859]). Ejercicios de traducción graduada de francés á español, dispuestos sobre los dos cursos del Maestro Francés por don Justino Laverdure, Oviedo, C. Uría Valdés.

LEYS, F. J. (h. 1721). Livre instructif, ou nouveau dictionnaire françois-espagnol / El gran tesoro de la lengua española, ò dicionario nuevo explicado en francés, manuscritos 1801-1806 de la biblioteca universitaria de Erlangen-Núremberg (eds. por L. Bray en 1993 -Erlangen, Fischer-) y Chart. A 466-469 de la Forschungs- und Landesbibliothek de Gotha.

Lhomond, Ch.-F. (1821). Gramática francesa de Lhomond. Enteramente refundida por Carlos Constante Letellier, [...] y enriquecida [...] por D. Juan Sánchez Ribera, Madrid, J. del Collado.

Lhuillier, Ch. M. L., C. J. PetiT (1810). Dictionnaire des termes de marine françaisespagnol et espagnol-français, París, Delance \& Belin.

LIAÑO, J. de [J. LEDEL] (1565). Vocabulario de los vocablos que mas comunmente se suelen vsar. Puestos por orden del Abecedario, en Frances, y su declaracion en Español, Alcalá de Henares, F. de Cormellas y P. de Robles. Reediciones citadas: 1647 (véase A. Lacavallería, Grammatica).

Littleton, A. C. (1879). Vocabulary of sea words in English, French, German, Spanish and Italian, Portsmouth, Griffin and Co. 
LlausÁs y MATA, J. (1855). Curso ecléctico elemental de lengua francesa, Barcelona, J. Verdaguer.

Llave, P. de la (1848). Vocabulario francés-español de términos de Artillería, y de los oficios y artes militares y civiles que tienen relación con ella, Segovia, E. Baeza.

Loвo, D. (1776). A nomenclature; or, Dictionary, in English, French, Spanish, and German, of the Principal Articles manufactured in this Kingdom; more particularly those in the hardware and cutlery trades; the goods imported and exported, and nautical terms, Londres / Birmingham, autor.

Lorenzo, J. de, G. de Murga, M. Ferreiro (1864). Diccionario marítimo español, que además de las voces de navegacion y maniobra en los buques de vela, contiene las equivalencias en francés, inglés é italiano, y las mas usadas en los buques de vapor, Madrid, T. Fortanet.

LosÁÑEZ, J. (1854). Gramática francesa elemental, Madrid, M. Romeral y Fonseca.

LUNA, A. de (1620). Ramilete [sic] de flores poeticas, y notables hieroglificos, en alabanza de las hermosas Damas deste tiempo, Toulouse, J. Maffre.

MaC-Veigh, H. (1872 [1857]). Método de Ahn. Segundo curso de Francés. Sexta edición revisada y aumentada con [...] un Diccionario de las voces contenidas en los dos cursos por D. Atalo Castañs, Madrid, C. Bailly-Baillière.

Martí, M. A., Ll. Bordas, J. CORTADA (1842-1848). Diccionario castellano-catalánlatino-francés-italiano, Barcelona, A. Brussi.

MARTINEZ, F. (1809). Le Nouveau Sobrino ou Grammaire espagnole-française, simplifiée et réduite à XIII leçons, Burdeos, viuda Laplace.

Martinez Lopez, P., F. MAURel (1839-1840). Diccionario francés-español y españolfrancés, París, Ch. Hingray.

Martínez SaAvedra, F. (1791). Compendio de la Gramatica Francesa, Sevilla, Vázquez \& Hidalgo.

MAUnORY, G. de (1701). Grammaire et Dictionnaire François et Espagnol, París, Viuda de C. Barbin. Reediciones citadas: 1704 (París, Viuda de C. Barbin; Bruselas, F. Foppens), 1708 (viuda Barbin).

MEGISERUS, H. (1603). Thesaurus polyglottus vel dictionarium multilingue ex quadragentis circiter linguis, dialectis, idiomatibus et idiotismis constans, Fráncfort del Meno, autor.

MELzI, G. B. (1878). Manual práctico de correspondencia francesa, que contiene [...] un Vocabulario comercial francés-español y español-francés, Paris, P. Ollendorff.

MELZI, G. B. (1878). Manuel pratique de correspondance espagnole contenant [...] un dictionnaire des termes de commerce espagnol-français et français-espagnol, París, $\mathrm{P}$. Ollendorff.

MinsheU, J. (1617). Ductor in linguas: The guide into the Tongues. With their agreement and consent one with another, as also their Etymologies, that is, the Reasons and Deriuations of all or the most part of Wordes, in these eleuen Languages, viz. 1. 
English, 2. British or Welsh, 3. Low Dutch, 4. High Dutch, 5. French, 6. Italian, 7. Spanish, 8. Portuguez, 9. Latine, 10. Greeke, 11. Hebrew, ec., Londres, J. Browne.

Molfino, S. C. (1861). Compendio de la gramática francesa, para uso de los españoles, Málaga, La Ilustración Española, J. García Taboadela.

MONFORT, L. (1815). Principios de Lengua Francesa para uso de los Españoles, Valencia, Esteban.

Moralejo, J. M. (1862 [1835]). Manual de conversaciones francesas y españolas, París, J. H. Truchy.

MoretTi, F. (1828). Diccionario militar Español-Francés [Francés-Español], Madrid, Imprenta Real.

MuÑoz, J. M. (s. a. [188?]). El idioma frances al alcance de todos, Barcelona, Gaceta Mercantil e Industrial, J. Balmes Planas.

NAVAS, L. de (1809-1810). Diccionario manual Español-Francés [Français et Espagnol] de los nombres de pertrechos y efectos de armamento de los navios de guerra. Manuscrito II/1504-1505 de la Real Biblioteca de Madrid.

Nemnich, Ph. A. (1793-1798). Allgemeines Polyglotten-Lexicon der Naturgeschichte mit erklaerenden Anmerkungen. Wörterbuch der Naturgeschichte in der deutschen, holländischen, dänischen, schwedischen, englischen, französischen, italienischen, spanischen und portugiesischen Sprache, Hamburgo, Nemnich; Leipzig, Böhme.

NeMnich, Ph. A. (1797). Waaren-Lexicon in zwölf Sprachen, Hamburgo, Nemnich; Leipzig, Böhme. Reediciones citadas: 1799 (An universal European dictionary of merchandise, in the English, German, Dutch, Danish, Swedish, French, Italian, Spanish, Portuguese, Russian, Polish \& Latin languages, Londres, J. Johnson).

Neuman, H. (1799). A Marine Pocket-Dictionary, of the Italian, Spanish, Portuguese and German Languages, with an English-French, and French-English Index, Londres, autor. Reediciones citadas: 1808 (A Marine Pocket-Dictionary of the Spanish, Portuguese, Italian and German Languages, Londres, Vernor, Hood \& Sharpe, J. Murray, T. Boosey, J. Aspener).

Nicot, J. (1606). Thresor de la langue francoyse, tant ancienne que moderne, París, D. Douceur.

Novella, P. A. (1813). Nueva gramática de la lengua francesa y castellana, Alicante, Imprenta de España.

Novilliers Clavel, G.-A. de (1629). Nomenclatura Italiana, Francesa y Española, Venecia, Barezzo Barezzi.

NoVísimo (1859). Novísimo diccionario francés-español y español-francés. El más completo de cuantos se han publicado en España y en el extranjero hasta hoy día. Redactado sobre el de Núñez de Taboada y aumentado con más de 12.000 voces y 12.000 acepciones nuevas que no se hallan en los de Capmany, Salvá, Martínez López y demás autores modernos, así nacionales como extranjeros, Barcelona, J. Oliveres.

NUEVO (1840-1841). Nuevo diccionario francés-español y español-francés, más completo que cuantos se han publicado hasta el día, redactado sobre el de Núñez de Taboada, y 
aumentado con más de 10.000 voces y 10.000 acepciones nuevas que no se hallan en el de dicho autor, Barcelona, A. Bergnes y Compañía.

NúÑEZ DE TABOADA, M. M. (1812). Diccionario español-francés y francés-español, más correcto y completo que todos los que se han publicado hasta ahora, sin exceptuar el de Capmany, París, Brunot-Labbé, Rey et Gravier, T. Barrois. Reediciones citadas: 1820 (Madrid, Sancha).

NúÑEZ DE TABOADA, M. M. (revisor) (1824). Arte de hablar bien francés de $P . N$. Chantreau, París, Seguin.

OCHOA, E. de (1842). Guia de la conversacion español-frances al uso de los viageros y de los estudiantes, París, Ch. Hingray; Madrid, C. Monier.

OCHOA, E. de (s. a.). Novísima guía de conversaciones modernas ó diálogos usuales y familiares en español y en francés, Madrid, Bailly-Bailliere.

O'HIER DE GRANDPRE, L.-M.-J. (1829). Répertoire polyglotte de la marine [...] suivi de cinq vocabulaires des termes techniques en Anglais, Espagnol, Allemand, Italien, et Portugais, París, Malher et Cie.

OlAVARrieta LACAlle, L. de (1895). Ejercicios de traducción francesa, Reus, hijos de Sanjuán.

ORRIT, E. 1843. Dictionnaire français-espagnol et espagnol-français, abrégé du dictionnaire de Martínez-López, adopté par le Conseil de l'Université, et rédigé sur le même plan, París, Ch. Hingray.

O'SCANlan, T. (1829). Cartilla práctica de la construcción naval dispuesta en forma de vocabulario con algunos apéndices, y las nomenclaturas francesa, inglesa e italiana, con su correspondencia en castellano, Madrid, M. de Burgos. Reediciones citadas: 1847 (Madrid, Imprenta Nacional).

O’Scanlan, T. (1831). Diccionario marítimo español, que ademas de las definiciones de las voces con sus equivalentes en frances, ingles e italiano, contiene tres vocabularios de estos idiomas con las correspondencias castellanas, Madrid, Imprenta Real.

Oudin, A. (1647). Nomenclature Françoise et Espagnole, París, A. Sommaville.

Oudin, C. (1607). Tesoro de las dos lenguas Francesa y Española, París, Marc Orry. Reediciones citadas: 1616 (París, Viuda de M. Orry), 1624-1625 (Bruselas, H. Antoine), 1645 ([...] Le tout corrigé \& reduit en meilleur ordre, par Antoine Oudin [...], París, A. Sommaville, A. Courbé, N. y J. Le Coste), 1650 y 1660 (Bruselas, J. Mommaert), 1675 (Lyon, M. Mayer).

Oudin, C. (1608). Dialogos muy apazibles, escritos en lengua Española, y traduzidos en Frances, París, Marc Orry. Reediciones citadas: 1622 ([...] Plus est adiousté vn Nomenclator de quelques particularitez qui se presentent à tout propos [...], París, $\mathrm{P}$. Billaine), 1604 (fecha ficticia; Dialogos en Español y Françes, Bruselas, F. Foppens), 1675 (Dialogos en Español y Frances, Bruselas, F. Foppens).

PAllas, P. S. (1787-1789). Linguarum totius orbis vocabularia comparativa, San Petersburgo, J. C. Schnoor. Reediciones citadas: 1790-1791 (San Petersburgo, J. C. Schnoor). 
Pallet, J. (1604). Diccionario muy copioso de la lengua española y francesa, París, M. Guillemot. Reediciones citadas: 1606-1607 (Bruselas, R. Velpius).

Palmireno, J. L. (1569). Vocabulario del humanista, Valencia, Pedro de Huete.

Perger, J. (1704). Nouvelle Grammaire de la Langue Espagnolle, París, P. Ribou.

PETIT (1811). Le Petit nécessaire des Français qui vont en Espagne, ou vocabulaire français et espagnol, contenant les mots et petites phrases les plus indispensables, Montpellier, A. Ricard.

PicAtoste Rodríguez, F. (1886). Diccionario francés-español y español-francés, Madrid, G. Estrada.

PIFERRER, F. (1841). Vocabulaire de poche espagnol-français et français-espagnol, Toulouse, Delsol, Pradel et Comp.

PIFERRER, F., M. de NEIRA (1846). Nouveau dictionnaire français-espagnol et espagnolfrançais, avec la prononciation figurée et l'accent prosodique, Toulouse, Bon \& Privat.

Pomey, F. (1667). Indiculus universalis, Lyon, A. Molin. Reediciones citadas: 1705 (Universo abreviado, Adonde estàn contenidos en diversas listas, casi todos los nombres de las obras de la Naturaleza, de todas las Ciencias, y de todas las Artes, con sus principales Términos. Indiculus universalis, Rerum ferè omnium, quae in mundo sunt, Scientiarum item, Aetiúmque nomina, aptè, brevitérque colligens. L'Univers en abrege. Où sont contenus en diverses listes presque tous les Noms des Ouvrages de la Nature, de toutes les Sciences \& de tous les Arts, avec leurs principaux Termes. [...] Traduit en Espagnol, par le P. F. T. Croset [...], Lyon, P. Valfray).

Pouvreau, S. (h. 1675). [Posible esbozo de diccionario cuatrilingüe vasco-francés-españolatín], ms. 8 del fondo celta y vasco de la Bibliothèque nationale de France.

Puiggarí, P. (revisor) (1841). El Novísimo Chantreau, ó Arte de hablar bien francés, gramática compuesta por D. Pedro Nicolas Chantreau, Perpiñán, J.-B. Alzine.

QuintANA, J. F. (1843-1845). Nuevo diccionario portátil español-francés y francésespañol, Burdeos, Chaumas-Gayet.

REeHORST, K. P. ter (1842). New Dictionary of Technical Terms, containing: 1. Commercial or Mercantile Terms, in seven different languages. 2. Judicial Terms, in six different languages. 3. Nautical Terms, in six different languages. 4. Denomination of Articles, in eight different languages, Londres, H. Hering; Ámsterdam, C. G. van der Post.

REEHORST, K. P. ter (1849). The mariner's friend, or polyglot indispensable, and technical dictionary, [...] in ten different languages. English, Dutch, German, Danish, Swedish, French, Italian, Spanish, Portuguese and Russian, Kampen, K. van Hulst.

ROBLES, L. de (1615). Advertencias y breve metodo, para saber leer, escrivir y pronunciar la lengua castellana, con buena ortografía, [...] puesto en frances por Juan Blanchet, París, F. Bourriquant.

Roca y María, S. (1750). Arte Francés, ò Nuevo methodo facilissimo, para Leer, Hablar, y Escrivir Francès, conforme à lo mas moderno, Barcelona, F. Suria. 
RodvilA, A. de (impresor) (1477). Introito e porta de quele que voleno imparare e comprender todescho a latino, cioe italiano, Venecia, A. de Rodvila. Reediciones citadas: 1510 (Vocabularius quattuor linguarum Latinae, Italicae, Gallicae \& Alamanicae, Roma, Mazzocchi), 1526 (Vocabulario de cinco lenguas Latina, Italiana, Francesa, Espagnola et Alemana, Venecia, F. Garrone).

RöDING, J. H. (1794-1798). Allgemeines Wörterbuch der Marine, Hamburgo, Nemnich; Leipzig, A. F. Böhme.

RoQues, J. M. (1896). Novísimo curso completo de francés, Madrid, J. Perales y Martínez.

SAINT-HILAIRE BlAnC [M.-J. Blanc Saint-Hilaire] (1847 [¿1840?]). Diccionario españolfrancés, conforme con los mejores diccionarios de las dos naciones, Lyon / París, SaintHilaire Blanc y Comp.).

SAINT-Hilaire Blanc [M.-J. Blanc Saint-Hilaire] (1859). Novísimo diccionario francesespañol y español-frances, París / Lyon, autor.

SaInT-Paul, Madame de (1840). Promenades instructives ou dialogues, Barcelona, J. Verdaguer.

SALAZAR, A. de (1614). Espexo general de la gramatica en dialogos, para saber la natural y perfecta pronunciacion de la lengua Castellana. Servirá tambien de vocabulario para aprenderla con mas facilidad, Ruán, A. Morront.

Salvá, V., J. B. GuIM, F. de P. NoRIEGA (1856). Nuevo diccionario frances-español y español-frances, París, Garnier. Reediciones citadas: 1880 (París, Garnier).

SAlvÁ, V. (1856). Nuevo diccionario frances-español y español-frances [formato de bolsillo], París, Garnier. Reediciones citadas: 1897 (París, Garnier).

SAUZEAU, Z. (1845). Nueva gramática de la lengua francesa, Madrid, M. de Burgos.

SCHEIDNAGEL, M. (1879). Nuevo prontuario y vocabulario práctico de los idiomas español, inglés y francés, Madrid, R. Labajos.

SEguin, P. (h. 1636). Dictionario español [español-francés]. Bibliothèque nationale de France, ms. español 298.

SEJournant, P. de (1759). Nouveau Dictionnaire Espagnol-François et Latin, composé sur les dictionnaires des Académies Royales de Madrid et de Paris, París, Ch.-A. Jombert. Reediciones citadas: 1790-1791 (Lyon, J. B. Delamollière).

SOBRINO, F. (1697). Nouvelle grammaire espagnole, mise en bon ordre et expliquée en françois, Bruselas, F. Foppens. Reediciones citadas: 1717 (Gramatica nueva Española y Francesa, Bruselas, F. Foppens), 1798 (Aviñón, Chambeau \& C.).

Sobrino, F. (1705). Dicionario nuevo de las lenguas española y francesa, Bruselas, F. Foppens. Reediciones citadas: 1721 (Bruselas, F. Foppens), 1734 (Diccionario [...] Con las Phráses y modos de hablar particuláres, sacadas de diferentes Autores Españoles, principalmente de Covarrubias, Saavedra, Quevedo, Gracian, Solis y del Diccionario de la Academia Real Española, Bruselas, P. Foppens), 1744 y 1760 (Bruselas, H.-A. Gosse). 
Sobrino, F. (1708). Dialogos nuevos en Español y Francés [...] con un Nomenclator al fin, Bruselas, F. Foppens. Reediciones citadas: 1787 (Aviñón, L. Chambeau).

SOLER Y ARQUÉS, C. (1866). Curso de lengua francesa, Vich, Soler hermanos.

SOLER Y ARQuÉS, C. (1884, $5^{\mathrm{a}}$ ed.). Lecciones de lengua francesa, Madrid, M. Ginés Hernández.

SOlER Y ARQUÉS, C. (1893). Novísimo diccionario manual franco-español e hispanofrancés, Madrid, viuda de Hernando.

SOTOMAYOR, B. de (1565). Grammatica con reglas muy prouechosas y necessarias para aprender a leer y escriuir la lengua Francesa, conferida con la Castellana, Alcalá de Henares, P. de Robles, F. de Cormellas. Reediciones citadas: 1647 (véase A. Lacavallería, Grammatica).

Sotuel, T. (1777). Diccionario universal de marina, manuscrito.

SUMARAN, J. Á. de (1621). Libro muy provechoso para aprender las lenguas, Múnich, viuda de Vergianam.

SUMARAN, J. Á. de (1626). Thesaurus fundamentalis, quinque linguarum [...] videlicet Latinae, Hispanicae, Gallicae, Italicae, \& Germanicae [...], Ingolstadt, Wilhelm Eder.

TARAZONA Y Dolz Del CASTEllar, G. (1898). Francés práctico, Valencia, M. Alufre.

TEJEDA, J. de (1629). Methode pour entendre facilement les Phrases et difficultez de la langue Espagnolle, París, autor.

TeCKlenborg, H. (1870). Internationales Wörterbuch der Marine über alle im Verkehr vorkommenden technischen Ausdrücke. 1. Aus Italienischen, Spanisch, Portugiesisch, Franszösisch, Holländisch, Dänisch, Schwedisch, Englisch in Deutsch. 2. Aus Deutsch in obige acht Sprachen, Bremen, J. G. Heyse.

TERREROS Y PANDO, E. de (1786-1793). Diccionario castellano con las voces de ciencias y artes y sus correspondientes en las tres lenguas, francesa, latina e italiana, Madrid, Viuda de Ibarra, B. Cano.

TOlHAUSEN, L. (1884). Nuevo diccionario de faltriquera español-francés y francésespañol, Leipzig, Tauchnitz. Reediciones citadas: 1914 (Nuevo diccionario de bolsillo español-francés y francés-español, Leipzig, B. Tauchnitz).

TORRE Y OCÓN, F. de la (1728). Nuevo Methodo breve, util, y necessario para aprender a escribir, entender, y pronunciar las dos principales Lenguas, Española, y Francesa, Madrid, J. de Ariztia.

TORRE y OCÓN, F. de la (1728-1731). El Maestro de las dos Lenguas. Diccionario Español, y Frances; Frances, y Español, Madrid, J. de Ariztia.

TORRECILla, P. M. de (revisor) (1850). Chantreau reformado, París, Rosa, Bouret y Cía.

TRAMARRÍA Y CARRANZA, F. de (1829). Gramática francesa para uso de los españoles, Madrid, Moreno.

TRAPANI, D. G. (1838). Diccionario español-francés y francés-español, París, Baudry. 
Trapani, D. G., A. de Rosily (1826). Nuevo diccionario español-francés y francésespañol, con la nueva ortografía establecida por la Academia Española, recopilado de los de Gattel, Capmany, Nunez-de-Taboada, Boiste, Laveaux etc., Paris, A. ThoisnierDesplaces.

TREPIED, H. (1889). Vocabulaire militaire espagnol-francais, París, L. Baudoin.

Trogney, J. (impresor) (1639). El grande Dictionario y Thesoro de las tres lenguas Española, Francesa y Flamenca, Amberes, C. J. Trogney. Reediciones citadas: 1640 (Amberes, C. J. Trogney).

Troullioud, J. (1884 [1881-1884]). Compendio de gramática francesa. Tomo IV: Ejercicios de sintaxis francesa, Madrid, G. Hernando.

VANWYN (1841). La Polyglotte, ou Recueil de neuf mil mots les plus usités dans huit langues et deux idiomes [...] français, allemand, anglais, russe, polonais, espagnol, hollandais, italien et idiomes russe-polonais. Avec cinq vocabulaires ou répertoires, français, hollandais, allemand, espagnol et anglais [...], Gante, Vanderhaeghe-Maya.

VERDADERO (1880). Verdadero Taboada. Completísimo diccionario español-francés y francés-español, más exacto y correcto que todos los que se han publicado hasta el presente sin exceptuar el de Capmany, Barcelona, E. Pujal.

Vert y Mercader, T. (1853). Compendio de la Gramática Francesa para uso de los Españoles, sacada de la de D. Pedro Nicolás Chantreau, Igualada, Jover y Serra.

VILA E IGLesias, F. (1850). El nuevo método - Gramática de la lengua francesa para uso de los españoles, Barcelona, viuda e hijos de Sierra.

VilAR Y GARCíA, C. (1894). Elementos de Fonética y Lexicología seguidos del Vocabulario franco-español y español-francés, Sevilla, C. de Torres y Daza.

VitToRi, G. (1609). Tesoro de las tres lenguas Francesa, Italiana y Española, Ginebra, Ph. Albert, A. Pernet. Reediciones citadas: 1606 [1616]-1617 (t. I, español-francés-italiano, Cologny, S. Crespin 1617; t. II, francés-italiano-español, Cologny, P. de la Rovière, 1616, en portada 1606; t. III, italiano-francés-español, Cologny, S. Crespin, 1617), 1637 (Ginebra, J. Crespin), 1671 (Ginebra: J.-A. y S. de Tournes).

VIVES, J. L. (1552 [1538]). Linguae Latinae exercitatio, Amberes.

VOCABULAIRE (1835). Vocabulaire du voyageur, ou Guide de l'Étranger; anglais-français, italien-français, espagnol-français, París, Ledoyen.

VOLtoIre (1620). L'interprect ou Traduction du François, Espagnol \& Basque, Lyon, A. Rouyer. Reediciones citadas: 1642 (Thresor des trois langues, Francoise, Espagnolle, et Basque, Bayona, F. Bourdot), 1684 (Thresor des trois lengues, Franceses, Espagnol, et Basque, Bayona, A. Fauvet), 1706 (Tresor des trois langues, française, espagnole et basque. [...] Avec un memoire en espagnol et françois composé de toutes sortes de mots très-curieux, Bayona, P. Fauvet).

WARMER, C. (1691). Gazophylacium decem linguarum Europaearum apertum, [...] in Sermone Germanico, Polonico, Bohemico, Belgico, Anglico, Latino, Gallico, Hispanico, Italico et Ungarico [...], Kosice. 


\section{b) Otras fuentes primarias citadas}

ACADEMIE FRANÇAISE (1740 [1694]). Dictionnaire de l'Académie Françoise, París, J.-B. Coignart. Reediciones citadas: 1798 (París, J.-J. Smits et Cie).

BesCHERELle, L.-N. (1845-1846). Dictionnaire national ou Dictionnaire universel de la langue française, París, Simon \& Garnier.

BiLlet, P.-P. (1673). Gramatica Francesa, Zaragoza, s. n.

BORDAS, L. (1856). Gramática práctica para aprender á leer, hablar y escribir el idioma francés, Barcelona, T. Gorchs.

BUFFON, comte de [Georges Louis Leclerc] (1749-1804). Histoire naturelle, générale et particulière, París, 44 vols. Traducida por José Clavijo (véase este autor).

Cisneros, D. de (1635 [1624]). Arte de Gramática Francesa en Español, Madrid, Imprenta del Reino.

ClAVIJO Y FAJARDO, J. (traductor) (1785-1805). Historia natural, general y particular, Madrid, J. Ibarra, 21 vols. Traducción de la Histoire naturelle de Buffon (véase este autor).

CORAIL DE SAINTE-Foy, F. de, et alii (1823). Maison rustique abrégée et hommage aux hommes vertueux, ou réunion des calendriers souvenirs de vertu, d'agriculture, de jardinage, des bâtimens et de santé, Toulouse, Viuda Tislet.

CoRmon, J.-L.-B. (1804). Le Maître d'espagnol, ou Élémens de la langue espagnole, à l'usage des Français, Lyon, B. Cormon \& Blanc.

CoT, L. (1824). Ejercicio práctico de la Gramática de Chantreau, para aprender la lengua Francesa, Barcelona, N. de Indar.

COT, L. (1825). Rudimentos gramaticales en francés y en español extractos de la Gramática de Chantreau y otros para aprender la lengua francesa, Barcelona, viuda Pla, V. Verdaguer.

COVARRuBias, S. de (1611). Tesoro de la lengua castellana o española, Madrid, L. Sánchez.

Delaborde, R. E. L. (1855). Novísimo arte teórico, práctico, analítico y sintético de lengua francesa para uso de los españoles, Madrid, Monier; París, Derache.

DiÉGuez Alonso, A. (1899). El Nuevo Chantreau ó Gramática Hispano-Francesa [...] Primer curso Fonologia y Lexicologia, Barcelona, Bastinos.

DiEGO DE GUADIX (h. 1593). Recopilación de algunos nombres arábigos, que los árabes (en España, Francia y Italia) pusieron a algunas ciudades y a otras muchas cosas. Manuscrito de la Biblioteca Colombina 59-I-24.

Domínguez, R. J. (1846-1847). Diccionario nacional o Gran diccionario clásico de la lengua española, Madrid, R. J. Domínguez.

ESTIENNE, R. (1539). Dictionaire Francoislatin, contenant les motz \& manieres de parler François, tournez en Latin, París, R. Estienne. 
Galmace, A. (1745). Adiciones a la Gramatica Francesa, que compuso el R. P. Nuñez, Madrid, s. n.

GAtTel, C.-M. (1797). Nouveau dictionnaire portatif de la Langue Françoise, Lyon, Bruyset aîné et Comp.

Grimaud de Velaunde, F. (1826). Método práctico para aprender los elementos de la Lengua Francesa, Madrid, Repullés.

Hidalgo, J. [Cristóbal de Chaves] (1609). Bocabulario de germania. En Romances de germanía de varios autores con su bocabulario al cabo por la orden del $a, b, c$, para declaración de sus términos y lengua, Barcelona, S. de Cormellas, ff. G6r-I11v.

JARON, J.-P. (1688). Arte nuevamente compuesto de la Lengua Francesa por la Española, Madrid, L. A. de Bédmar y Baldivia.

LACAVALlERÍA, A. (impresor) (1647). Grammatica con reglas muy prouechosas, y necessarias para aprender a leer, y escriuir la lengua Francesa, conferida con la Castellana. Con vn estilo de escrivir, hablar, y pronunciar las dos lenguas, el Frances en Castellano, y el Castellano en Frances. A la fin va vna Egloga, y otras cosas en las dos lenguas, no menos prouechosas para qualquier que entrambas lenguas quisiere deprender, Barcelona, A. Lacavallería.

LiTTRE, É. (1863-1873). Dictionnaire de la langue française, París, Hachette.

METHODO (1718). Methodo per encontrar ab facilitát lo arreglament de varios y differents vocables segons la construcció del Univérs, ab los principals termes dels arts, y ciencias, manuscrito del Centre de Lectura de Reus.

Oudin, C. (1597). Grammaire et observations de la langue Espagnolle, París, M. Orry. Reediciones citadas: 1606 (Grammaire Espagnolle espliquee en François, París, M. Orry).

Oudin, C. (1605). Refranes o proverbios españoles traduzidos en lengua Francesa, París, M. Orry.

Oudin, C. (traductor) (1614). L'Ingénieux Don Quixote de La Manche, París, J. Fouet.

Picatoste Rodríguez, F. (1882). Diccionario popular de la lengua castellana, Madrid, G. Estrada.

Pluche, A.-N. (1732-1750). Le spectacle de la nature, París, viuda de Estienne. Traducido al español por Terreros (véase este autor, El espectáculo...).

REAL ACADEMIA ESPAÑOLA (1726-1739), Diccionario de la lengua castellana [Diccionario de Autoridades], Madrid, F. del Hierro. Reediciones citadas: 1770 (solo tomo primero A-B, Madrid, J. Ibarra), 1780 ([...] reducido a un tomo para su más fácil uso, Madrid, J. Ibarra).

RESTAUT, P. (1739). Abrégé des principes de la grammaire françoise, París, Jean Desaint.

SOBRINO, F. (1720). Secretario Español enseñando la manera de escrivir cartas españolas, segun el estilo moderno, esplicadas en Francès, Bruselas, F. Foppens.

Terreros, E. de (1753-1755). El espectáculo de la naturaleza, Madrid, G. Ramírez. Traducción de Le spectacle de la nature, de Pluche (véase este autor). 
Trevoux, Dictionnaire de (1704). Dictionnaire universel françois et latin, Trévoux, E. Ganeau. Reediciones citadas: 1743 (París, Viuda Delaulne).

Un Literato (1817). El Nuevo Chantreau, ó Gramática de la Lengua Francesa, sacada de los mejores Gramáticos modernos, y arreglada al plan que ha seguido en la suya el Señor Abate de Lévizac, Burdeos, P. Beaume.

VORSTERMAN, W. (impresor) (1520). Vocabulario para aprender Franches, Espannol y Flaminco, Amberes, W. Vorsterman. Reediciones citadas: 1530 (Amberes: W. Vorsterman).

\section{Estudios citados}

ACERo DurÁNTEZ, I. (1992). "En torno a la historia de la lexicografía española: el Nomenclator de Hadrianus Junius". Voces 3, 109-116.

ACERo DurÁNTEZ, I. (1993). "La deuda de la lexicografía plurilingüe para con Nebrija: Hadrianus Junius y Heinrich Decimator”. Anuario de Lingüística Hispánica 9, 9-22.

ACERo DurÁnTez, I. (1996). "La Sylva Vocabulorum de Heinrich Decimator, muestra de la lexicografía plurilingüe del siglo XVI". Actas del III Congreso Internacional de Historia de la Lengua Española, Madrid, Arco Libros, 1996, t. II, 1125-1135.

ACERo DURÁNTEZ, I. (1998). "La enseñanza de las lenguas vernáculas en el Renacimiento: a propósito de Jacques de Liaño". Actas del Congreso Internacional sobre Humanismo y Renacimiento, J. Matas Caballero, J. Manuel Trabado Cabado, M. L. González Álvaro y M. Paramio Vidal (eds.), León, Secretariado de Publicaciones de la Universidad, t. II, 151-160.

ACERo DurÁNTEZ, I. (2003). “La lexicografía plurilingüe del español”. Lexicografía española, A. M. Medina Guerra (ed.), Barcelona, Ariel, 175-204.

ACERo DurÁnteZ, I. (2008). "Lexicografía plurilingüe de los siglos XVI y XVII". Philologia Hispalensis 22.

Ahumada, I. (2006). Diccionario bibliográfico de la metalexicografía del español (orígenes-año 2000), Jaén, Servicio de Publicaciones de la Universidad de Jaén.

Ahumada, I. (2009). Diccionario bibliográfico de la metalexicografía del español (años 2001-2005), Jaén, Servicio de Publicaciones de la Universidad de Jaén.

Alvar EzQuerra, M. (1991). “Antiguos diccionarios plurilingües del español”. Actas del Primer Coloquio Internacional de Traductología, B. Lépinette Lepers, M. A. Olivares Pardo y E. Sopeña Balordí (eds.), Valencia, Universitat de València, Departamento de Filología Francesa e Italiana, 7-14.

Alvar EzQuerra, M. (1993). "El Diccionario de Terreros". Lexicografía descriptiva, Barcelona, Bibliograf, 249-259. Aparecido como "Presentación" de la ed. facsimilar del Diccionario de Terreros, Madrid, Arco Libros, 1987, t. I, V-XVI.

Alvar EzQUerRA, M. (1997a). "La Nomenclatura de Lorenzo de Robles". Contribuciones al estudio de la lingüística hispánica. Homenaje al profesor Ramón Trujillo, M. 
Almeida y J. Dorta (eds.), Barcelona, Montesinos, t. II, 15-26. Reeditado en De antiguos y nuevos diccionarios, Madrid, Arco Libros, 2002, 239-252.

Alvar EzQuerra, M. (1997b). "Los repertorios léxicos de Alejandro Luna”. Thesaurus. Boletín del Instituto Caro y Cuervo 52, 45-51. Reeditado en De antiguos y nuevos diccionarios, Madrid, Arco Libros, 2002, 232-238.

Alvar EzQuerra, M. (2005). "La lexicografía plurilingüe del siglo XVIII”. E-Excellence, 11-4-2009, www.liceus.com.

Álvarez De Miranda, P. (1992). "En torno al Diccionario de Terreros". Bulletin hispanique 94/2, 559-572.

Ayala Castro, M. C. (1992). "Nomenclatures de l'espagnol (1526-1800). Considérations générales sur la nature et la fonction des nomenclatures". Cahiers de Lexicologie 61/2, 127-160.

Ayala Castro, M. C. (1996). "El Indiculus universalis de François Pomey". Estudios de historia de la lexicografía del español, M. Alvar Ezquerra (ed.), Málaga, Servicio de Publicaciones de la Universidad de Málaga, 49-59.

Ayala CAStro, M. C. (1998). "Los otros diccionarios del español: clasificaciones metódicas del siglo XIX”. Diccionarios, frases, palabras, M. Alvar Ezquerra y G. Corpas Pastor (eds.), Málaga, Servicio de Publicaciones de la Universidad de Málaga, 85-100.

AZORÍN FERNÁNDEZ, D. (1985). "Un capítulo de lexicografía hispánica. En torno al vocabulario bilingüe francés-español de Jacques Ledel”. Lexis 9/1, 101-117.

AZORÍN FERNÁNDEZ, D. (2000). Los diccionarios del español en su perspectiva histórica, Alicante, Publicaciones de la Universidad de Alicante.

BAJO PÉREZ, E. (2000). Diccionarios. Introducción a la historia de la lexicografía del español, Gijón, Trea.

Besse, H. (2001). "Comenius et sa 'méthode d'enseignement graduée'”. Langue Française $131,7-22$.

BIERBACH, M. (1995). "Trois précurseurs de Ménage en France au XVI ${ }^{\mathrm{e}}$ siècle: Bovelles, Le Bon et Bourgoing". Gilles Ménage (1613-1692), grammairien et lexicographe: le rayonnement de son oeuvre linguistique, I. Leroy-Turcan y T. R. Wooldridge (eds.), Lyon, SIEHLDA, Université de Lyon III.

Bourland, C. B. (1933). "The Spanish School-Master and the Polyglot Derivatives of Noel de Berlaimont's Vocabulare”. Revue hispanique 81, 283-318.

BRAY, L. (2000). Matthias Kramer et la lexicographie du français en Allemagne au XVIII siècle, Tubinga, Niemeyer.

Breva Claramonte, M. (1991). "Las ideas lingüísticas del siglo XVIII en Lorenzo Hervás: la descripción de las lenguas del mundo". Anuario del Seminario de Filología vasca "Julio de Urquijo" (ASJU): International Journal of Basque Linguistics and Philology 25/3, 769-781. 
Breva Claramonte, M. (1994). La didáctica de las lenguas en el Renacimiento. Juan Luis Vives y Pedro Simón Abril, con selección de textos, Bilbao, Universidad de Deusto.

BREva Claramonte, M. (2003). "Specialized lexicography for learning Spanish in sixteenth-century Europe". History of Linguistics 1999. Selected Papers from the Eighth International Conference on the History of the Language Sciences, S. Auroux (ed.), Ámsterdam / Filadelfia, J. Benjamins, 83-95.

BRUÑA CUEVAS, M. (1996). "Le problème de l'orthographe française dans les grammaires de français à l'usage des Espagnols et dans les dictionnaires bilingues français-espagnol et espagnol-français (XVI ${ }^{\mathrm{e}}-\mathrm{XVIII}{ }^{\mathrm{e}}$ siècles)". La lingüistica francesa: gramática, historia y epistemología, E. Alonso, M. Bruña y M. Muñoz (eds.), Sevilla, Grupo Andaluz de Pragmática, t. I, 85-101.

BRUÑA CuEvas, M. (1999a). "L'universalité de la langue française dans les grammaires de français pour les Espagnols et dans les dictionnaires bilingues antérieurs à 1815". Historiographia Linguistica 26/1-2, 37-71. Reeditado en History of Linguistics in Spain II / Historia de la Lingüística en España II, E. F. K. Koerner y H.-J. Niederehe (eds.), Ámsterdam / Filadelfia, J. Benjamins, 2001, 229-262.

BRUÑa CUEVAS, M. (1999b). "Las mejoras aportadas a la traducción por el diccionario de Capmany (1805)”. La traducción en España (1750-1830). Lengua, literatura, cultura, F. Lafarga (ed.), Lérida, Edicions de la Universitat de Lleida, 99-110.

BRUÑa CUEVAS, M. (2000a). "L'enseignement de la prononciation française aux Espagnols (XVI ${ }^{\mathrm{e}}$ et XVII ${ }^{\mathrm{e}}$ siècles)". Grammaire et enseignement du français, 1500-1700 (= Orbis / Supplementa, 16), J. De Clercq, N. Lioce y P. Swiggers (eds.), Lovaina / París, Peeters, 61-96.

BRUÑa CuEVAS, M. (2000b). "El primer diccionario francés-español con transcripción fonética (Cormon, 1800)". La Philologie française à la croisée de l'an 2000. Panorama linguistique et littéraire, M. Serrano Mañes, L. Avendaño Anguita y M. C. Molina Romero (eds.), Granada, APFFUE, Universidad de Granada, t. II, 165-177.

BRUÑA CUEVAS, M. (2002). "La pronunciación figurada del español en los diccionarios bilingües español-francés (siglos XIX-XX)". Hacia la unidad en la diversidad: difusión de las lenguas europeas, E. Fernández Vallina, V. González Martín y M. Montesinos Caperos (eds.), Salamanca, Ambos Mundos, 75-89.

BRUÑa Cuevas, M. (2003a). "Los estudios sobre la lexicografía franco-española de todos los tiempos". Anales de Filología Francesa 11, 55-78.

BRuÑa Cuevas, M. (2003b). "Un diccionario bilingüe enciclopédico (Ramón Joaquín Domínguez, 1845-1846)". El texto como encrucijada. Estudios franceses y francófonos, M. J. Salinero Cascante e Ignacio Iñarrea Las Heras (eds.), Logroño, Servicio de Publicaciones de la Universidad de La Rioja, t. II, 283-294.

BRuÑa Cuevas, M. (2004). "Les dictionnaires encyclopédiques bilingues françaisespagnol". Le français face aux défis actuels. Histoire, langue et culture, J. Suso López y R. López Carrillo (eds.), Granada, Universidad de Granada, APFUE, GILEC, t. II, 35-44.

BRUÑa Cuevas, M. (2005a). "Obras sobre la lengua francesa existentes en la biblioteca del monasterio de San Millán de la Cogolla (siglos XVII y XVIII)". Berceo 148, 153-178. 
Bruña Cuevas, M. (2005b). "Histoire des transcriptions phonétiques dans les dictionnaires français-espagnol et espagnol-français". Cahiers de Lexicologie 87/2, 97 140.

BRuña CuEvas, M. (2006a). "El Diccionario universal francés y español (1743) de Antonio María Herrero". La cultura del otro: español en Francia, francés en España. La culture de l'autre: espagnol en France, français en Espagne, M. Bruña, M. G. Caballos, I. Illanes, C. Ramírez y A. Raventós (eds.), Sevilla, APFUE, SHF, Departamento de Filología Francesa de la Universidad de Sevilla, 133-147.

BRUÑa CuEVAS, M. (2006b). "El Nuevo diccionario francés-español y español-francés (1856) atribuido a Vicente Salvá". Bulletin hispanique 108/2, 577-609.

Bruña Cuevas, M. (2007). "Las ediciones del Tesoro de Oudin y las del Tesoro de Vittori”. Percepción y realidad. Estudios francófonos, M. T. Ramos y C. Desprès (eds.), Valladolid, Departamento de Filología Francesa y Alemana, 117-126.

BRuña Cuevas, M. (2008a). “Metalexicografía francés-español”. Linguistique plurielle, B. Lépinette y B. Gómez (eds), Valencia, Universitat de València, Universidad Politécnica de Valencia, 73-77. Reedición en Synergies Espagne 3, 2010.

BRUÑa CuEvas, M. (2008b). "El lugar de edición de los diccionarios francés-español (siglos XVI-XXI)". La lexicografía bilingüe y didáctica: ayer y hoy (= Anexos Revista de Lexicografía 8), M. Campo Souto, E. M. González González y J. I. Pérez Pascual (eds.), La Coruña, Universidade da Coruña, 9-20.

Bruña Cuevas, M. (2008c). "El Promptuario de Josep Broch en catalán, castellano y francés (1771)". Vox Romanica 67, 183-203.

BRUÑa CuEvas, M. (en prensa). "Le Dictionario castellano - Dictionnaire françois Dictionari català (1642) et la Gramatica [...] para aprender a leer, y escriuir la lengua francesa (1647), publications des imprimeurs Lacavalleria”. Apprentissages, usages et pratiques des langues étrangères en Europe (1400-1720), J.-F. Chappuit y M. Zuili (eds.), París, Presses Universitaires de Paris Sorbonne.

Caravolas, J.-A. (1991). "Les deux Januas, celle de Bathe et celle de Coménius". Rassegna italiana de linguistica applicata 23/2, 1-27.

Carriscondo, F. M., N. M. Contreras, L. Ruiz, I. SÁnchez, M. I. SAncho (2000). "La lexicografía bilingüe del español y las lenguas románicas". Cinco siglos de lexicografía del español, I. Ahumada (ed.), Jaén, Universidad de Jaén, 269-306.

CASAnOvas, I. (1931). Josep Finestres: estudis biográfics, estudi preliminar, elogi funeral, vida i escrits, documents, Barcelona, Biblioteca Balmes.

CAstillo PeÑA, C. (2006). "La Nomenclatura italiana, francesa y española de Noviliers Clavel: apuntes de lexicografía histórica". Actas del VI Congreso Internacional de Historia de la Lengua Española, J. J. Bustos Tovar y J. L. Girón Alconchel (eds.), Madrid, Arco Libros, t. II, 1319-1332.

CAzorla Vivas, M. C. (2002a). Lexicografía bilingüe de los siglos XVIII y XIX con el español y el francés. Tesis doctoral, Universidad Complutense. E-Prints Complutense, 11-4-2009, http://eprints.ucm.es/tesis/fl1/ucm-t26053.pdf. 
Cazorla Vivas, M. C. (2002b). "Una incursión en lexicografía bilingüe del siglo XVIII: la obra de Francisco Sobrino". IV Congreso de Lingüistica General, M. D. Muñoz Núñez, A. I. Rodríguez-Piñero Alcalá, G. Fernández Smith y V. Benítez Soto (eds), Cádiz, Área de Lingüística General de la Universidad de Cádiz, Servicio de Publicaciones de la Universidad de Cádiz, Servicio de Publicaciones de la Universidad de Alcalá, t. II, 607-616.

CAzOrla Vivas, M. C. (2002c). "Una aportación más a la lexicografía bilingüe del siglo XVIII: el Nouveau dictionnaire espagnol, français et latin de Pierre de Séjournant (1759)". Presente y futuro de la Lingüística en España. La Sociedad de Lingüística, 30 años después, A. Bernabé, J. A. Berenguer, M. Cantarero y J. C. de Torres (eds.), Madrid, Sociedad Española de Lingüística, t. II, 353-361.

CAZORLA VIVAS, M. C. (2002d). "Panorama de la lexicografía hispano-francesa del siglo XVIII: El Diccionario nuevo portátil y manual francés-español de Diego A. de Godoy (1795)". Res Diachronicae 1, 115-123.

CAzorla Vivas, M. C. (2002-2004). "El Diccionario Universal Francés-Español de Herrero y Rubira (1744)”. Archivo de Filología Aragonesa 59-60, 301-323.

CAZORla VIVAS, M. C. (2003). "Lexicografía bilingüe del siglo XIX. La primera edición del Diccionario francés-español y español-francés de R.-J. Domínguez”. Adquisición, enseñanza y contraste de lenguas, bilingüismo y traducción, I. Doval Reixa y M. R. Pérez Rodríguez (eds.), Vigo, Universidade de Vigo, 63-70.

CAZORLa Vivas, M. C. (2006a). "La difusión de los vocabularios bilingües portátiles y el Diccionario español-francés de C. M. Gattel (1798)". Actas del V Congreso Andaluz de Lingüistica General. Homenaje al profesor José Andrés de Molina Redondo, J. D. Luque Durán (ed.), Granada, Granada Lingvistica, t. III, 1091-1102.

CAzorla Vivas, M. C. (2006b). "Lexicografía plurilingüe del siglo XIX”. E-Excellence, 11-4-2009, www.liceus.com.

Cazorla Vivas, M. C. (2008). "Diccionarios en el Siglo de las Luces: el repertorio bilingüe de N. González de Mendoza (1761-1763)". La lexicografía bilingüe y didáctica: ayer y hoy (= Anexos Revista de Lexicografía 8), M. Campo Souto, E. M. González González y J. I. Pérez Pascual (eds.), La Coruña, Universidade da Coruña, 2940 .

Choppin, A. (coord.) (1995). Les Manuels scolaires en France de 1789 à nos jours. Tomo 6: Les Manuels d'espagnol, París: INRP (Service d'histoire de l'éducation), Publications de la Sorbonne.

Christ, H. (1991). "Matthias Kramer. Portrait d'un maître de langues suivi de quelques remarques concernant de futures recherches". Documents pour l'histoire du français langue étrangère ou seconde 8, 19-25.

ClaEs, F. (2000). "Vocabulaires et livres de conversation pour apprendre le français aux Pays-Bas espagnols entre 1550 et 1700". Grammaire et enseignement du français, 1500-1700 (= Orbis / Supplementa 16), J. De Clercq, N. Lioce y P. Swiggers (eds.), Lovaina / París, Peeters, 217-235. 
Collet Sedola, S. (1996). "Gramáticos y gramáticas: España en Francia (1600-1650)". Studia Aurea. Actas del III congreso de la AISO, I. Arellano, M. C. Pinillos, F. Serralta y M. Vitse (eds.), Pamplona, GRISO; Toulouse, LEMSO, t. I, 161-168.

Colombo Timelli, M. (1992). "Dictionnaires pour voyageurs, dictionnaires pour marchands ou la polyglossie au quotidien aux $\mathrm{XVI}^{\mathrm{e}}$ et $\mathrm{XVII}^{\mathrm{e}}$ siècles". Lingvisticae Investigationes 16/2, 395-420.

Colombo Timelli, M. (1993). "Il francese del Dictionaire des huict langages". Parcours et rencontres. Mélanges de langue, d'histoire et de littérature françaises offerts à Enea Balmas, París, Klincksieck, t. I, 133-166.

Colón, G., A.-J. Soberanas (1986). Panorama de la lexicografia catalana. De les glosses medievals a Pompeu Fabra, Barcelona, Enciclopèdia Catalana.

COlÓN DOMÈnECH, G., M. P. PEREA SABATER (2005). Una nomenclatura catalanofrancesa del 1718. Edició $i$ estudi lingüístic, Castellón de la Plana, Societat Castellonenca de Cultura.

CoOper, L. (1960a). "Girolamo Vittori y César Oudin: un caso de plagio mutuo". Nueva Revista de Filología Hispánica 14/1-2, 3-20.

COOPER, L. (1960b). "Sebastián de Covarrubias: una de las fuentes principales del Tesoro de las dos lenguas francesa y española (1616) de César Oudin”. Bulletin hispanique $62 / 4,365-397$.

COOPER, L. (1962). "El Recueil de Hornkens y los diccionarios de Palet y de Oudin". Nueva Revista de Filología Hispánica 16/3-4, 297-328.

Corcuera Manso, J. F., A. Gaspar Galán (1996). "Los comienzos de la expansión de la lengua francesa a través de las gramáticas publicadas dentro y fuera del territorio francés. El caso de España". Documents pour l'histoire du français langue étrangère ou seconde $18,173-188$

Corcuera Manso, J. F., A. GASPAR GAlan (1999). La lengua francesa en España en el siglo XVI. Estudio y edición del vocabulario de Jacques de Liaño (Alcalá de Henares, 1565), Zaragoza, Prensas Universitarias de Zaragoza.

CORvo SÁNCHEZ, M. J. (2005). “Juan Ángel de Zumaran: intérprete y maestro de lenguas entre los alemanes en el siglo XVII". Estudios filológicos alemanes 7, 123-144.

Corvo SÁnchez, M. J. (2007a). "Repertorios lexicográficos en lenguas modernas en los siglos XV y XVI: estudio e ilustración”. Historia de la lexicografía española (= Anexos Revista de Lexicografía 7), M. Campos Souto, R. Cotelo García y J. I. Pérez Pascual (eds.), La Coruña, Universidade da Coruña, 39-46.

CORvo SÁnChez, M. J. (2007b). Los libros de lenguas de Juan Ángel de Zumaran. La obra de un maestro e intérprete de lenguas español entre los alemanes del siglo XVII. Fráncfort del Meno, P. Lang.

CORvo SÁnCHEZ, M. J. (2008). "Breve historia de la lexicografía bilingüe española y alemana hasta el siglo XIX”. Philologia Hispalensis 22. 
Cundín SANTOS, M., Á. LíBAno ZumalacÁRRegui (2000). "La lexicografía bilingüe euskera-castellano, castellano-euskera: aproximación historiográfica". Cinco siglos de lexicografía del español, I. Ahumada (ed.), Jaén, Universidad de Jaén, 307-340.

DichtL, G. (1998). "Los comienzos de la lexicografía hispano-neerlandesa". Lexicografías iberorrománicas: problemas, propuestas y proyectos, M. T. Fuentes Morán, R. Werner (eds.), Fráncfort del Meno, Vervuert; Madrid, Iberoamericana, 13-32.

ECHENIQUE Elizondo, M. T. (1998). "Los diccionarios trilingües en la lexicografía vasca: teoría y práctica de un ideal multisecular". Lexicografias iberorrománicas: problemas, propuestas y proyectos, M. T. Fuentes Morán, R. Werner (eds.), Fráncfort del Meno, Vervuert; Madrid, Iberoamericana, 33-47.

ECHENIQUE ELIZONDO, M. T. (2008). “¿Tradición múltiple en la lexicografía vasco-latinorománica? Algunas notas sobre el componente fraseológico en diccionarios bilingües y trilingües de los siglos XVI al XVIII: de Nicolas Landuchio (1562) a Jose Maria Aizpitarte (c. 1785)". Philologia Hispalensis 22.

ÉtIENVRE, F. (2001). Rhétorique et patrie dans l'Espagne des Lumières. L'oeuvre linguistique d'Antonio de Capmany (1742-1813), París, Champion.

FABBri, M. (1979). A Bibliography of Hispanic Dictionaries: Catalan, Galician, Spanish, Spanish in Latin America and the Philippines. Appendix: A Bibliography of Basque Dictionaries, Imola, Galeati.

FALiU-LaCourt, C. (1982). "Juan y Alejandro de Luna”. Criticón 19, 83-112.

FERNÁNDEZ DíAZ, M. C. (1985). Antonio de Capmany, una visión original del problema de la traducción y del aprendizaje del francés en la España del siglo XVIII, Santiago de Compostela, Universidad de Santiago de Compostela.

Fernández Fraile, M. E., J. Suso LóPez (1999). La enseñanza del francés en España (1767-1936). Estudio histórico: objetivos, contenidos, procedimientos, Granada, Método.

FinOLI, A. M. (1993). "Jacques Bourgoing: l'etimologia e le riflessioni sulla lingua del secolo XVI". Parcours et rencontres. Mélanges de langue, d'histoire et de littérature françaises offerts à Enea Balmas, P. Carile, G. Dotoli, A. M. Raugei, M. Simonin y L. Zilli (eds.), París, Klincksieck, t. I, 263-280.

Fischer, D., J. F. GARcía BASCuÑANA, M. T. GÓMEZ (2004). Repertorio de gramáticas y manuales para la enseñanza del francés en España (1565-1940), Barcelona, PPU.

FLORES VARELA, C. D. (1978). "Les deux premières méthodes de français pour Espagnols publiées en Espagne". Verba 5, 341-350.

Foulche-Delbosc, R. (1962). Bibliographie hispano-française. 1477-1700, Nueva York, Kraus Reprint. Es reproducción de la ed. de Nueva York, Hispanic Society of America, 1912-1914.

Fuertes GutiÉRrez, M. (2004). "La actividad como gramático de Lorenzo Hervás y Panduro (1735-1809)". Nuevas aportaciones a la historiografía lingüística, C. J. Corrales Zumbado, J. Dorta Luis, A. N. Torres González, D. Corbella Díaz, F. M. Plaza Picón (eds.), Madrid, Arco Libros, t. I, 529-537. 
Gago Jover, F. (2008). "Glosarios y diccionarios militares del siglo XIX”. El diccionario como puente entre las lenguas y culturas del mundo, D. Azorín Fernández (ed.), Alicante, Universidad de Alicante, 670-677.

GALlinA, A. (1959). Contributi alla storia della lessicografia italo-spagnola dei secoli XVI e XVII, Florencia, L. S. Olschki.

GARCÍA ARANDA, M. Á. (2003). Un capítulo de la lexicografía didáctica del español: nomenclaturas hispanolatinas (1493-1745). Tesis doctoral, Universidad Complutense. E-Prints complutense, 11-4-2009, http://eprints.ucm.es/tesis/fll/ucm-t26673.pdf. Editada en 2006 como La enseñanza del léxico latino en el Renacimiento. Nebrija, su "Lexicon seu paruum vocabularium" y las nomenclaturas del español, Jaén, Servicio de Publicaciones de la Universidad de Jaén.

García ArAnda, M. Á. (2005). "La Janua linguarum de Juan Amos Comenio, un capítulo de la lexicografía onomasiológica". Nuevas aportaciones a la historiografía lingüística, C. J. Corrales Zumbado, J. Dorta Luis, A. N. Torres González, D. Corbella Díaz, F. M. Plaza Picón (eds.), Madrid, Arco Libros, t. I, 551-560.

GARCÍA ARANDA, M. Á. (2005-2006). "La información fonética en la lexicografía menor del español: Le petit nécessaire des français qui vont en Espagne (1811)". Revista de lexicografía 12, 159-176.

GARCíA BASCuÑANA, J. F. (1992-1993). “La obra lexicográfica de Nemesio Fernández Cuesta: su significación en la historia de los diccionarios bilingües francés-español, español-francés”. Universitas Tarraconensis. Filologia 14, 45-61.

GARCÍA BASCUÑANA, J. F. (1996). “Contribución al estudio de los diccionarios bilingües francés-español / español-francés: aproximación histórica y metodológica”. Léxico y diccionarios, E. Forgas (ed.), Tarragona, Departament de Filologies Romàniques, Universitat Rovira i Virgili, 91-103.

García BascuñanA, J. F. (1999). "De Gattel y B. Cormon a Capmany y Núñez de Taboada: en torno a ciertos aspectos y procedimientos de la lexicografía bilingüe francés-español entre 1790 y 1812”. La traducción en España (1750-1830). Lengua, literatura, cultura, F. Lafarga (ed.), Lérida, Edicions de la Universitat de Lleida, 111120.

GARCIA BASCUÑANA, J. F. (2005). "Nemesio Fernández Cuesta lexicographe et traducteur (1818-1893): à propos de l'institutionnalisation et formation des professeurs de français en Espagne pendant la seconde moitié su XIX ${ }^{\mathrm{e}}$ siècle". Documents pour l'histoire du français langue étrangère ou seconde 33-34, 265-276.

GARCIA BASCUÑANA, J. F. (2008). "En torno al 'diccionario trilingüe' (castellano-francéscatalán) de Pere Lacavalleria (Barcelona, 1642): originalidad, imitación, plagio". Linguistique plurielle, B. Lépinette y B. Gómez (eds.), Valencia, Universitat de València, Universidad Politécnica de Valencia, 537-547.

Gemmingen, B. von (1986). "Untersuchungen zu César Oudins Tesoro de las dos lenguas francesa y española (1607)". Schwerpunkt Siglo de Oro, H.-J. Niederehe (ed.), Hamburgo, Buske, 215-234. 
GEMMINGEN, B. von (1993). "Un 'dictionnaire de poche' du XVII ${ }^{\mathrm{e}}$ siècle, le Vocabulario para facilmente y breuemente deprender a leer, escrebir, y hablar la lengua castellana de François Huillery (1661)". Actes du XX Congrès International de Linguistique et Philologie Romanes, G. Hilty (ed.), Tubinga, Francke, t. IV, 621-635.

GEMMINGEN, B. von (2001). "Estudios sobre el Diccionario español-francés del abate Claude-Marie Gattel (1790)". Estudios de lexicografía diacrónica del español, A. M. Medina Guerra (ed.), Málaga, Universidad de Málaga, 211-242.

GiLi GAYA, S. (1951). "El primer diccionario español-francés”. Clavileño 12, 36-37.

Guerrero Ramos, G. (1992). "La lexicografía bilingüe desde Nebrija a Oudin". Actas del IV Congreso Internacional de EURALEX, Barcelona, Biblograf, 463-471.

GuZMÁn Galiano, A. J. (2001). "Los diccionarios especializados del español: la obra de Terreros y Pando". Tendencias en la investigación lexicográfica del español. El diccionario como objeto de estudio lingüístico y didáctico, S. Ruhstaller y J. Prado Aragonés (eds.), Huelva, Universidad de Huelva, 445-455.

INCLÁN GARCÍA-RoBÉS, L. (1990). Studia comeniana: la aportación lingüística y pedagógica de Juan Amos Comenio, Barcelona, Publicaciones de la Universidad.

LABARre, A. (1975). Bibliographie du Dictionarium d'Ambrogio Calepino (1502-1779), Baden-Baden, V. Koerner.

LePinetTe, B. (1990a). "La lexicographie franco-espagnole avant le Tesoro de las dos lenguas de César Oudin (1606)". Travaux de linguistique et de philologie 28, 316-342.

LePinette, B. (1990b). "Étude du Tesoro de las dos lenguas (Paris, 1607) de César Oudin". Iberoromania 33, 28-57.

LePinette, B. (1991). "Les Dialogues (1618) de César Oudin”. Actas del Primer Coloquio Internacional de Traductología, B. Lépinette Lepers, M. A. Olivares Pardo y E. Sopeña Balordi (eds.), Valencia, Universitat de València, Departamento de Filología Francesa e Italiana, 139-145.

LEPINETTE, B. (2000). L'enseignement du français en Espagne au XVIII siècle dans ses grammaires. Contexte historique, concepts linguistiques et pédagogie, Münster, Nodus.

LEPINETTE, B. (2001). El francés y el español en contraste y en contacto (siglos XV-XVII). Estudios de historiografía lingüistica. Lexicografía. Gramática. Traducción, Valencia, Universistat de València.

LindeMANN, M. (1994). Die französischen Wörterbücher von den Anfängen bis 1600. Enstehung und typologische Beschreibung, Tubinga, Niemeyer.

Lliteras, M. (1989). "Estudio Introductorio" a su edición de la Gramática castellana de Vicente Salvá, Madrid, Arco Libros, 7-64.

Martín Gamero, S. (1961). La enseñanza del inglés en España (desde la Edad Media hasta el siglo XIX), Madrid, Gredos.

MARTín Mingorance, L. (1994). "La lexicografía onomasiológica”. Aspectos de lexicografía contemporánea, H. Hernández Hernández (ed.), Barcelona, Biblograf, 1527. 
MARtínez EgIDO, J. J. (2002). "El Tesoro de Oudin (1607/1616) y el Vocabulario de Franciosini (1620): dos diccionarios bilingües del español". Con Alonso Zamora Vicente, J. C. Rovira Soler (ed.), Alicante, Universidad de Alicante, t. II, 815-823.

MARTíNEZ EGIDO, J. J. (2006). "La lexicografía bilingüe y plurilingüe de los siglos XVI y XVII". E-Excellence, 11-04-2009, www.liceus.com.

MARY JOAN (1962). "Minsheu's Guide into the Tongues and Somner's Dictionarium". Mediaeval Studies 24, 375-377.

Messner, D. (1993). "Ein Dicionário dos dicionários portugueses". Studien zur portugiesischen Lexikologie, D. Messner y A. Schönberger (eds.), Fráncfort del Meno, TFM, 61-174.

MichelenA, L. (1958). "Introducción" a la edición de M. Agud Querol y L. Michelena de Dictionarium Linguae Cantabricae (1562), San Sebastián, Diputación de Guipúzcoa, 748. Reimpreso en Sobre historia de la lengua vasca, J. A. Lakarra, M. T. Echenique y B. Urgell (eds.), San Sebastián, Gráficas Izarra, 1988, t. II, 762-782.

Moreu Huet, N. (1990). Pierre-Nicolas Chantreau (1741-1808) et sa grammaire, Barcelona, Publicacions Universitat de Barcelona.

MuÑoz GARrigós, J. (1996). “Ambrosio de Salazar, lexicógrafo”. Actas del III congreso internacional de historia de la lengua española, A. Alonso González, L. Castro Ramos, B. Gutiérrez Rodilla y J. A. Pascual Rodríguez (eds.), Madrid, Arco Libros, t. II, 14751484.

Murgades, J. (1989). "Notícia d'un diccionari manuscrit català-francès del 1718". Actes del vuitè col.loqui internacional de llengua i literatura catalanes, A. M. Badia i Margarit y M. Camprubí (eds.), Barcelona, Publicacions de l'Abadia de Montserrat, t. II, 109-120.

NiEDEREHE, H.-J. (1987). “Les dictionnaires franco-espagnols jusqu'en 1800”. Histoire, Épistémologie, Langage 9/2, 13-26.

NIEDEREHE, H.-J. (1988). "Les dictionnaires bilingues français-espagnol et espagnolfrançais au XVIII ${ }^{\mathrm{e}}$ siècle". Travaux de Linguistique et de Philologie 26, 33-47.

NIEDEREHE, H.-J. (1994). Bibliografia cronológica de la lingüistica, la gramática y la lexicografía del español (BICRES). Desde los principios hasta el año 1600, Ámsterdam / Filadelfia, J. Benjamins.

NiEDEREHE, H.-J. (1999). Bibliografia cronológica de la lingüística, la gramática y la lexicografía del español (BICRES II). Desde el año 1601 hasta el año 1700, Ámsterdam / Filadelfia, J. Benjamins.

NIEDEREHE, H.-J. (2005). Bibliografia cronológica de la lingüistica, la gramática y la lexicografía del español (BICRES III). Desde el año 1701 hasta el año 1800, Ámsterdam / Filadelfia, J. Benjamins.

NIETO JimÉNEZ, L. (2000a). "Vocabularios y glosarios del español de los siglos XIV al XVI”. Revista de Filología Española 80/1-2, 155-180. 
NiETO JiMÉnEZ, L. (2000b). "Repertorios lexicográficos españoles menores en el siglo XVI". Cinco siglos de lexicografía del español, I. Ahumada (ed.), Jaén, Universidad de Jaén, 203-223.

PABLO NÚÑEZ, L. (2006). "Un ejemplo curioso de la lexicografía bilingüe hispano-francesa de los siglos XVI y XVII: el Vocabulario para facilmente y brieuemente deprender a ler, escrebir, y hablar la Lengua Castellana (1661) de François Huillery". Cuatrocientos años de la lengua del Quijote. Estudios de historiografía e historia de la lengua española, M. Fernández Alcaide y A. López Serena (eds.), Sevilla, Publicaciones de la Universidad de Sevilla, 449-462.

PABlo NúÑEZ, L. (2008a). Lexicografía hispano-francesa de los siglos XVI y XVII: estudio $y$ catálogo de los repertorios. Tesis doctoral, Universidad Complutense.

Pablo NúÑEZ, L. (2008b). "Dos ejemplares de la supuesta edición inexistente del diccionario de Vittori de 1614". Res Diachronicae 6, 112-118.

Peligry, C. (1987). "César Oudin et l'enseignement de l'espagnol sous Louis XIII". Deux siècles de relations hispano-françaises, de Comynes à Madame d'Aulnoy, D.-H. Pageaux (ed.), París, L'Harmattan, 31-43.

Pensado, J. L. (1987). "Portugués y castellano en la Puerta de las lenguas abierta". Philologica I. Homenaje a D. Antonio Llorente, J. Borrego Nieto, J. J. Gómez Asencio y L. Santos Río (eds.), Salamanca, Ediciones Universidad de Salamanca, 307-336.

PINILla MARTíneZ, J. (2008). La traducción técnica y científica en España durante el siglo XVIII. Estudio traductológico de la obra en español de H. L. Duhamel du Monceau (1700-1782). Tesis doctoral, Universidad de Valencia.

PuChe RocA, M. S. (1996). El diccionario nuevo de las lenguas española y francesa de Francisco Sobrino: fuentes, contexto y estructura interna, Alicante, Secretariado de Publicaciones de la Universidad.

QuemadA, B. (1968). Les dictionnaires du français moderne (1539-1863). Étude sur leur histoire, leurs types et leurs méthodes, París, Didier.

Quilis MERÍn, M. (2002). “Consideraciones lexicográficas sobre el glosario de botánica en cuatro lenguas (1795-1798) de Antonio José de Cavanilles y el Diccionario de las artes y las ciencias de Esteban Terreros y Pando". SEHL 2001. Estudios de Historiografía Lingüística, M. Á. Esparza Torres, B. Fernández Salgado y H.-J. Niederehe (eds.), Hamburgo, H. Buske, t. II, 951-962.

QuiLIS Merín, M. (2007). "Las tareas lexicográficas en el siglo XIX: los diccionarios de Ramón Joaquín Domínguez". Historia de la lexicografía española (= Anexos de la Revista de Lexicografía 7), M. Campos Souto, R. Cotelo García y J. I. Pérez Pascual (eds.), La Coruña, Universidade da Coruña, 141-152.

REDOndo Rodríguez, M. J. (2006a). "El Quinque / Lingvarum, Latinae, / Teuthonicae, Gallicae, Hispanicae, Italicae, / dilucidissimus dictionarius [...] de J. Steelsius, heredero del Introito e porta de A. Rottweil y base de los anónimos plurilingües del siglo XVI". Cuatrocientos años de la lengua del Quijote. Estudios de historiografía e historia de la lengua española, M. Fernández Alcaide y A. López Serena (eds.), Sevilla, Publicaciones de la Universidad de Sevilla, 533-545. 
REDONDO RodRÍGUEZ, M. J. (2006b). “John Minsheu, ¿multiplagiario, innovador o difusor de fantasmas léxicos?". Diacronía, lengua española y lingüística, J. Rodríguez Molina y D. M. Sáez Rivera (eds.), Madrid, Síntesis, 427-438.

RICO, A., J. SOLÀ (1995). Gramàtica i lexicografia catalanes: sintesi histórica, Valencia, Universitat de València.

Roig, C. (1995). "El Nuevo diccionario francés-español de Antonio de Capmany". La Traducción. Metodología, Historia, Literatura. Ámbito hispanofrancés, F. Lafarga, A. Ribas y M. Tricás (eds.), Barcelona, PPU, 75-80.

Rossebastiano BART, A. (1984). Antichi vocabolari plurilingui d'uso popolare. La tradizione del 'Solenissimo Vochabuolista', Alessandria, Orso.

Rueda Rueda, M., F. J. Grande AlijA, V. Grande Rodríguez (2004). "J. A. Comenius y su papel como precursor en la enseñanza de lenguas extranjeras". Nuevas aportaciones a la historiografia lingüística, C. J. Corrales Zumbado, J. Dorta Luis, A. N. Torres González, D. Corbella Díaz y F. M. Plaza Picón (eds.), Madrid, Arco Libros, t. II, págs. 1481-1490.

SÁEz RiVERA, D. M. (2002). "Vida y obra de Francisco Sobrino (con breves noticias sobre Félix Antonio de Alvarado y Fray Gerónimo de Gracián)". En su edición de los Diálogos nuevos en español y en francés (1708) de Francisco Sobrino (= Anexos Revista Lemir), Valencia.

SÁez RiverA, D. M. (2005). "El Diccionario castellano, francés y catalán (1642) de Pere Lacavallería: indicios de una política lingüística en el siglo XVII”. Revista de Filología Románica 22, 97-119.

SÁEz RiverA, D. M. (2006). “L'Interprect ou Traduction du François Espagnol \& Basque (1620) de Voltoire en el marco vascorrománico y europeo". Oihenart. Cuadernos de Lengua y Literatura 21, 441-452.

SÁEz RiverA, D. M. (2007). La lengua de las gramáticas y métodos de español como lengua extranjera en Europa (1640-1726). Tesis doctoral, Universidad Complutense. EPrints complutense, 11-4-2009, http://eprints.ucm.es/7813.

Salas QuesadA, P. (2007). “Amato Lusitano y su Dioscórides: léxico español y portugués". Historia de la lexicografía española (= Anexos de la Revista de Lexicografía 7), M. Campos Souto, R. Cotelo García y J. I. Pérez Pascual (eds.), La Coruña, Universidade da Coruña, 163-172.

SAN ViCENTE, F. (1995). Bibliografia de la lexicografía española del siglo XVIII, Abano Terme, Piovan.

SAN Vicente, F. (1995). "Innovación y tradición en el Diccionario (1786-1793) de E. de Terreros y Pando". Sapere linguistico e sapere enciclopedico, L. Pantaleoni y L. Salmon Kovarski (eds.), Bolonia, CLUEB, 139-158.

SAN VICENTE, F. (2008). "El alfabeto italiano y el Diccionario castellano de Esteban de Terreros y Pando". Esteban Terreros y Pando: vizcaíno, polígrafo y jesuita. III Centenario, 1707-2007, S. Larrazábal Basáñez y C. Gallastegi (eds.), Bilbao, Universidad de Deusto, 361-386. 
SÁNCHEZ EsCRIBANO, F. J. (1979). James Howell: un hispanista inglés del siglo XVII. Tesis doctoral, Universidad de Zaragoza.

SÁNCHEZ EscribANO, F. J. (1983). "Los diccionarios políglotos de James Howell: fuentes y aportaciones personales". Atlantis 5, 5-22.

SÁNCHEZ ESCRIBANO, F. J. (2008). "La lexicogafría plurilingüe inglesa en los siglos XVI y XVII: los diccionarios de James Howell”. Philologia Hispalensis 22.

SÁNCHEZ PÉREZ, A. (1992). Historia de la enseñanza del español como lengua extranjera, Madrid, SGEL.

SANCHEZ RegueIRA, I. (1982). "César et Antoine Oudin: étude comparative des éditions de son Thrésor et son importance dans le domaine de la Lexicographie”. Verba 9, 329-340.

SECO, M. (1985). "Un lexicógrafo romántico: Ramón Joaquín Domínguez". Philologica Hispaniensia in honorem Manuel Alvar, Madrid, Gredos, t. II, 619-629. Reeditado como "Ramón Joaquín Domínguez", Estudios de lexicografía española, Madrid, Paraninfo, 1987, 152-164.

SOUTO GARRIDO, F. (2002). "Notas sobre la enseñanza del español en Francia en la época de Luis XIII: la labor de los pedagogos españoles". SEHL 2001. Estudios de Historiografía Lingüística, M. Á. Esparza Torres, B. Fernández Salgado y H.-J. Niederehe (eds.), Hamburgo, H. Buske, 465-479.

SuÁREZ GÓMEZ, G. (1956). La enseñanza del francés en España (comentario a una bibliografía establecida hasta 1850). Tesis doctoral, Universidad Complutense. Editada, presentada y comentada por J. F. García Bascuñana y E. Juan Oliva, 2008, La enseñanza del francés en España hasta 1850. ¿Con qué libros aprendian francés los españoles?, Barcelona, PPU.

SuÁrEZ GómEZ, G. (1961). “Avec quels livres les Espagnols apprenaient le français (15201850)". Revue de littérature comparée 35, 159-171, 330-346, 512-523.

SuPIOT, A. (1991). "Un diccionario bilingüe (español-francés, francés-español) del siglo XVIII. El Diccionario Nuevo de Francisco Sobrino". Traducción y adaptación cultural España-Francia, M. L. Donaire y F. Lafarga (eds.), Oviedo, Publicaciones de la Universidad de Oviedo, 493-502.

VERDEYEN, R. (1925-1935). Colloquia et Dictionariolum septem linguarum, Amberes, Nederlandsche Boekhandel (Uitgave van de Vereeniging der Antwerpsche Bibliophilen $39,40,42)$.

VERDONK, R. A. (1979). "Contribución al estudio de la lexicografía española en Flandes en el siglo XVII (1599-1705)”. Boletín de la Real Academia Española 59, 289-369.

VERDONK, R. A. (1988). "El diccionario plurilingüe llamado Anónimo de Amberes (1639), reflejo de la lexicografía española en Flandes”. Actas del I Congreso Internacional de Historia de la Lengua Española, M. Ariza, A. Salvador y A. Viudas (eds.), Madrid, Arco Libros, t. I, 995-1002.

VERDONK, R. A. (1989). "Le Recueil de H. Hornkens (Bruxelles, 1599), premier dictionnaire français-espagnol". Actes du XVIII Congrès International de Linguistique et de Philologie Romanes, D. Kremer (ed.), Tubinga, Niemeyer, t. IV, 61-70. 
VERDONK, R. A. (1990). "La importancia del Recueil de Hornkens para la lexicografía bilingüe del Siglo de Oro". Boletín de la Real Academia Española 70, 69-109.

VERDONK, R. A. (1991). "La lexicographie bilingue espagnol-français, français-espagnol”. Wörterbücher, Dictionaries, Dictionnaires: Ein internationales Handbuch zur Lexikographie / An International Encyclopedia of Lexicography / Encyclopédie internationale de lexicographie, F. J. Hausmann, O. Reichmann, H. E. Wiegand y L. Zgusta (eds.), Berlín / Nueva York, W. de Gruyter, t. III, 2976-2987.

Verdonk, R. A. (1992a). "La dette de César Oudin envers le Recueil de H. Hornkens et ses conséquences pour la lexicographie espagnole du 17e siècle". Linguistique hispanique (actualités de la recherche), G. Luquet (ed.), Limoges, PULIM, 9-23.

VerdonK, R. A. (1992b). “La importancia de la parte 'francés-español' del Diccionario nuevo de F. Sobrino para la lexicología y la lexicografía del español de los siglos de oro". Actas del II Congreso Internacional de historia de la lengua española, J. M. Mendoza y A. Narbona (eds.), Madrid, Pabellón de España, t. II, 1359-1365.

VerdonK, R. A. (1994). "La lexicografía española en Flandes. Confrontación del Diccionario nuevo de Sobrino (Bruselas, 1705) con su fuente principal: el Tesoro de Oudin (Bruselas, 1660)". Voz y Letra 5/1, 105-127.

VERDONK, R. A. (1998). "La lexicografía española en un área periférica del Imperio. Balance provisional de una investigación sobre los diccionarios neerlandés-español y francés-español publicados en Flandes durante el Siglo de Oro". Actas del IV Congreso Internacional de Historia de la Lengua Española, C. García Turza, F. González Bachiller y J. Mangado Martínez (eds.), Logroño, Servicio de Publicaciones de la Universidad de La Rioja, t. II, 391-400.

Videgain, X. (2000). Voltoire. Interprect ou Traduction du Français, Espagnol \& Basque, Pau, ICN.

ZuILI, M. (2006). "César Oudin y la difusión del español en Francia en el siglo XVII”. La cultura del otro: español en Francia, francés en España. La culture de l'autre: espagnol en France, français en Espagne, M. Bruña, M. G. Caballos, I. Illanes, C. Ramírez y A. Raventós (eds.), Sevilla, APFUE, SHF, Departamento de Filología Francesa de la Universidad de Sevilla, 278-289.

\author{
Manuel Bruña Cuevas \\ mbruna@us.es \\ Universidad de Sevilla \\ Facultad de Filología \\ Calle Palos de la Frontera \\ 41003 Sevilla
}

